
Agroforestry and Forestry in Sulawesi series:

\section{Gender, livelihood and land in South and Southeast Sulawesi}

Elok Mulyoutami, Endri Martini, Noviana Khususiyah, Isnurdiansyah and Suyanto

Working paper no. 158 


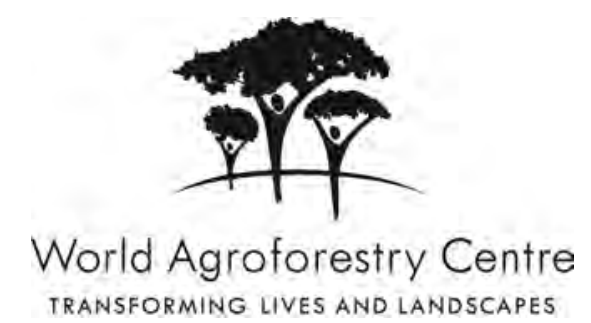

\section{Correct citation:}

Mulyoutami E; Martini E, Khususiyah N, Isnurdiansyah, Suyanto. 2012. Agroforestry and Forestry in Sulawesi series: Gender, livelihoods and land in South and Southeast Sulawesi. Working paper 158. Bogor, Indonesia: World Agroforestry Centre (ICRAF) Southeast Asia Regional Program. 74p. DOI: 10.5716/WP12057.PDF.

Titles in the Working Paper Series aim to disseminate interim results on agroforestry research and practices and stimulate feedback from the scientific community. Other publication series from the World Agroforestry Centre include: Agroforestry Perspectives, Technical Manuals and Occasional Papers.

Published by the World Agroforestry Centre

ICRAF Southeast Asia Regional Program

Jalan CIFOR, Situ Gede, Sindang Barang

Bogor 16115, Jawa Barat

[PO Box 161, Bogor 16001]

Indonesia

Tel: +622518625415

Fax: +622518625416

Email: icraf-indonesia@cgiar.org

http://www.worldagroforestry.org/sea

(C) World Agroforestry Centre 2012

Working Paper 158

\section{Photos:}

The views expressed in this publication are those of the author(s) and not necessarily those of the World Agroforestry Centre.

Articles appearing in this publication may be quoted or reproduced without charge, provided the source is acknowledged.

All images remain the sole property of their source and may not be used for any purpose without written permission of the source. 


\section{About the authors}

Elok Mulyoutami began her research at the World Agroforestry Centre (ICRAF) Southeast Asia Regional Office, focusing on local ecological knowledge and farming systems in 2003. She has a Bachelor of Anthropology from Padjadjaran University in Bandung, Indonesia, and is currently undertaking a Master of Rural Sociology at the Bogor Agricultural Institute, Indonesia. Her current focus of research is the wider social issues of demography and population, specializing in gender issues.

Endri Martini has been working for ICRAF since 2002 on different issues of agroforestry from biodiversity conservation, payments for environmental services and farmers capacity development. Currently she works at ICRAF as an agroforestry extension specialist. She received her bachelor degree in Forestry and her master degree in Natural Resources and Environmental management.

Noviana Khususiyah is a socioeconomic and livelihood specialist at the World Agroforestry Centre (ICRAF) Southeast Asia Regional Office. Her focus is household surveys of socioeconomic data: education, land use, poverty, income equity, labour use, profit, community livelihood strategies, the environment and gender. She has a Master of Economics, majoring in Regional and Rural Development Planning concentrating on Environmental Economics, obtained from Bogor Agricultural University, Indonesia.

Isnurdiyansyah gained his Bachelor of Agribusiness Economics from Bogor Agricultural University in 2010. He has been involved in several studies as a consultant in the field of socioeconomics. He start worked at the World Agroforestry Centre from 2009, then move to Ministry of Agriculture until 2011. He joined again the World Agroforestry Centre in 2012 as a research assistant in the Economic Policy Unit to support research on socioeconomics and livelihood.

Dr. S Suyanto has more than 15 years experience in natural resource management and institutional analysis. He has worked at the ICRAF-Southeast Asian Regional Research Programme based in Indonesia since 1994, developing a range of skills in socio-economic, natural resource economics, econometrics and institutional analysis. He conducted a study on the evolution of indigenous land tenure and tree resource management in the buffer zone of Kerinci National Seblat Park in Sumatra 
for his PhD dissertation. In the last five year, He managed several research projects relate on climate change, namely (1). "Efficient and Fair ways of Avoiding Carbon Emissions in Indonesia's Forest Margins: next steps in Negotiation Support Systems" (Ford Foundation Project); (2) "Sustainable livelihood options and carbon rights: a basis for efficient and fair emission reduction in the Central Kalimantan Ex-Mega Rice Project" (AUSAID Project); (3) "Fair, Efficient and Sustainable Emission Reduction from Land Use in Indonesia (FESERLUI)" - (Packard Project); (4) “Accountaibility and local level initiative to reduce emission from deforestation and degradation in Indonesia" (ALLREDDI-EU Project). He is currently leading the economic and policy analysis unit in ICRAF's Indonesia. 


\begin{abstract}
As part of an assessment of community livelihood systems of the Agroforestry and Forestry in Sulawesi (AgFor) project, gender is an important factor to capture the different livelihood options of the community, and their strategies to improve those options, in relation to environmental management. The underlying premise is that women and men have different strategies in managing natural resources that lead to different problems, and also different types of solutions. This study focused on gender issues, community livelihood options and the land management. The methods of gathering primary data were structural group discussions and household interviews covering two districts in South Sulawesi, and two districts in South Sulawesi. Gender gaps were determined at district and provincial levels using the Gender Development Index, Human Development Index and Gender Empowerment Index. Within these indexes, female participation in decision making was indicated as very low while their contribution to community income was also much lower than men. However, in reality, at the community level, it was seen that women's participation in decision making was potentially high in conducive situations in respecting their rights to the land, supporting their contribution to market, as well as acknowledging their contribution to household and community income.
\end{abstract}

Keywords: Gender, natural resource management, land, livelihoods, farming systems 


\section{Acknowledgements}

The authors would like to thank Kusdianawati, Badri Dwi Meyldi, Syamsidar, Heru T. Maulana and Rahma R. Talui, for their contribution in facilitating discussions, and for the household survey enumerators for their work within the household interviews. We highly appreciate the excellent support from the AgFor Sulawesi Project Bantaeng and Kendari teams, and the local and the local non-government organisations (NGOs) LSM Balang and Operation Wallacea Trust. Thanks to Janudianto and all team in Livelihood Baseline Survey, Carol Colfer for her assistance in improving quality of this manuscript, also to Nyanda Smith for assistance in editing the manuscript Most of all, thanks to all of the villagers who participated in this survey. 


\section{Contents}

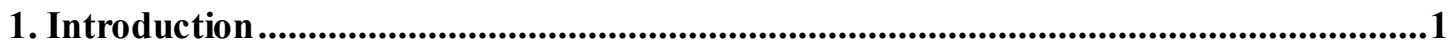

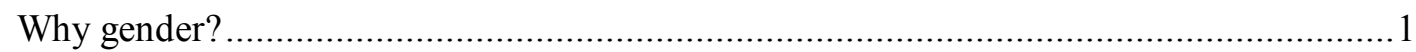

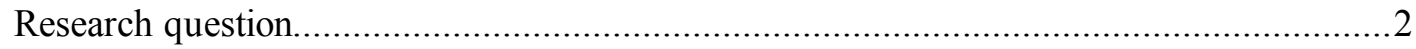

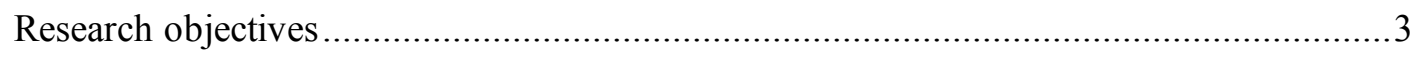

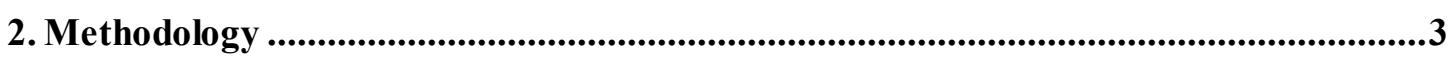

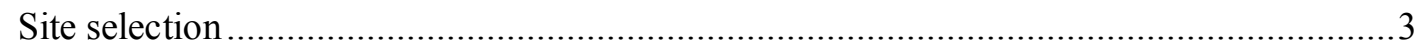

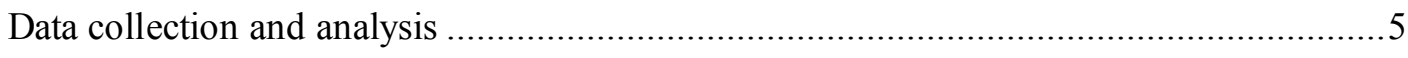

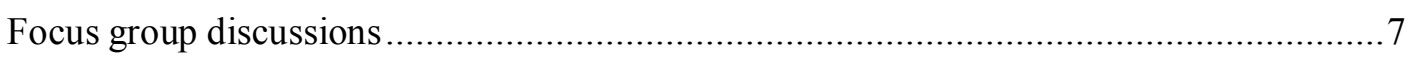

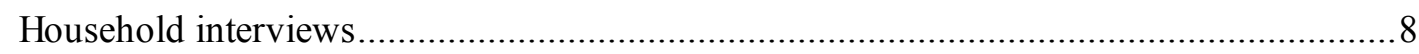

3. General overview of the sites...........................................................................................8

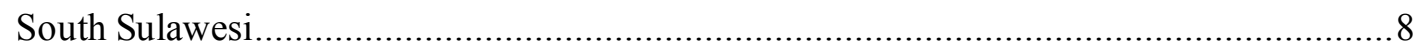

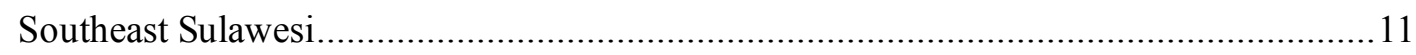

4. Gender development and empowerment index......................................................12

5. Gender, livelihood, land and management in South Sulawesi........................................21

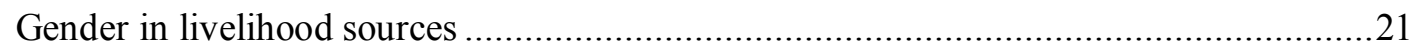

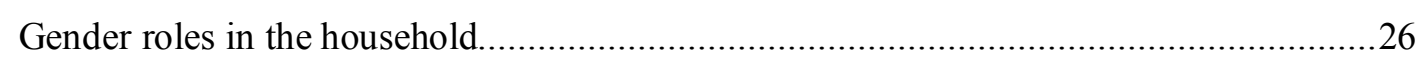

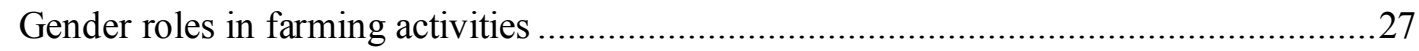

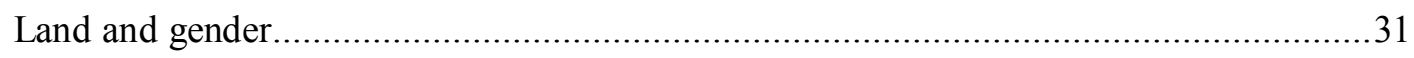

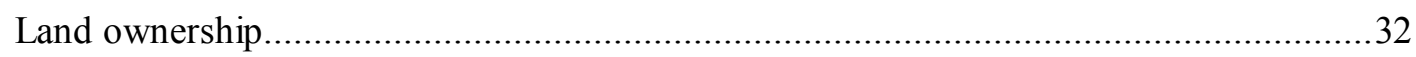

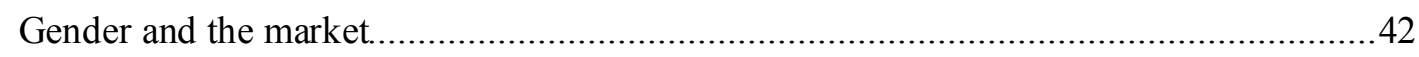

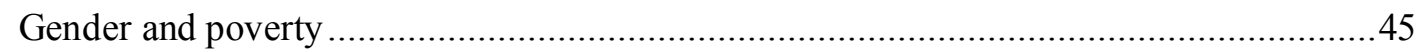

6. Gender, livelihood and land in Southeast Sulawesi ..........................................................48

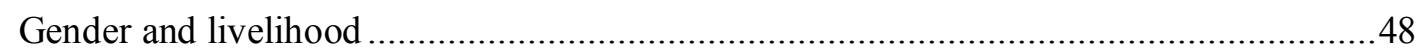

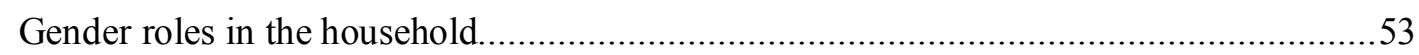

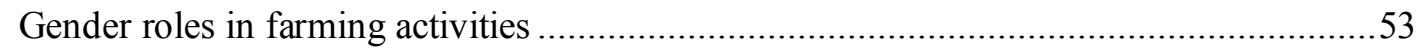

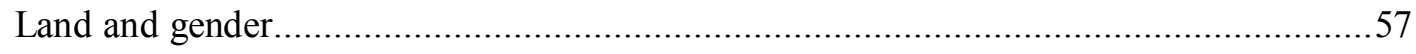

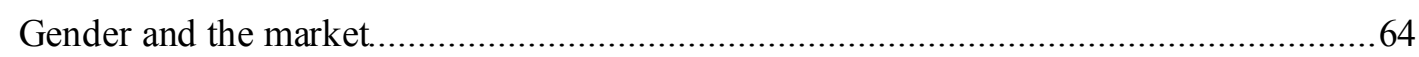

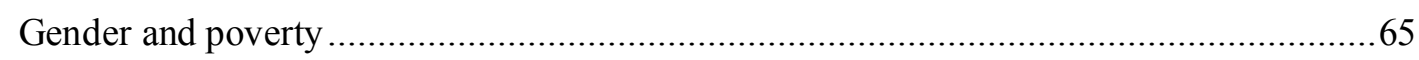

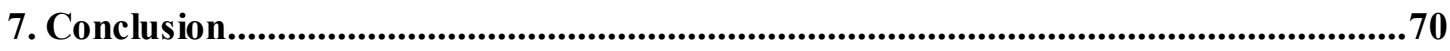

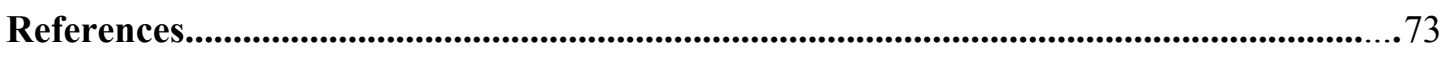




\section{List of Figure}

Figure 1. Location of baseline study in South Sulawesi........................................................... 4

Figure 2. Location of baseline study in Southeast Sulawesi....................................................... 5

Figure 3. Human and Gender Development Index for 2010 in South Sulawesi, Bulukumba and

Bantaeng districts, Southeast Sulawesi, and Konawe and Kolaka districts. (Data source:

Pembangunan Manusia Berbasis Gender Tahun 2005-2011, Corporation between BPS and

Kementerian Pemberdayaan Perempuan dan Perlindungan Anak)....................................... 13

Figure 4. Gap between HDI and GDI from 2004 to 2012 in South Sulawesi, Bulukumba and

Bantaeng. (Data source: Pembangunan Manusia Berbasis Gender Tahun 2005-2011,

Corporation between BPS and Kementerian Pemberdayaan Perempuan dan Perlindungan

Anak)......

Figure 5 Gap between HDI and GDI from 2004 to 2012 in Southeast Sulawesi, Konawe and

Kolaka. (Data source: Pembangunan Manusia Berbasis Gender Tahun 2005-2011,

Corporation between BPS and Kementerian Pemberdayaan Perempuan dan Perlindungan

Anak)

Figure 6. Quadrant analysis of gaps between HDI and GDI, and DEM. Data source: BPS and

Kementrian Pemberdayaan Perempuan dan Perlindungan Anak 2012. Pembangunan

Manusia Berbasis Gender Tahun 2005-2011.

Figure 7. Human and Gender Development Index, and Gender Empowerment Index in South

Sulawesi province, Bulukumba and Bantaeng districts from 2004 to 2012. (Data source: BPS

and Kementrian Pemberdayaan Perempuan dan Perlindungan Anak 2012. Pembangunan

Manusia Berbasis Gender Tahun 2005-2011).

Figure 8. Human and Gender Development Index, and Gender Empowerment Index in Southeast

Sulawesi, Konawe and Kolaka districts from 2004 to 2012. Data Source: BPS and

Kementrian Pemberdayaan Perempuan dan Perlindungan Anak. 2012. Pembangunan

Manusia Berbasis Gender Tahun 2005-2011).

Figure 9. Importance of land-based livelihood sources for women from male and female perspectives

(Horticulture refers to maize). Data source: FGD.

Figure 10. Gender involvement in livelihood sources based on the perceptions of men and women.

Data source: FGD. 26

Figure 11. Gender roles in farming system activities in the whole study areas in South Sulawesi.

Data source: FGD. 28

Figure 12. Gender roles in traditional agroforest. Data source: FGD 31 
Figure 13. Gender division of tasks in maize production and paddy cultivation in irrigated paddy fields. Data source: FGD.

Figure 14. Livelihood and environment functions of each land use system based on gendered points of view. Data source: FGD

Figure 15. Livelihood and environment functions from each land use system based on village typologies. Data source: FGD 36

Figure 16. Gendered perceptions of the importance of mixed-garden systems. Data source: FGD. 37 Figure 17 Perception of the importance of mixed-garden systems in each village typology. Data source: FGD. 38

Figure 18. Gender perceptions of the importance of irrigated paddy field systems. Data source: FGD.

Figure 19. Perception of the importance of irrigated paddy fields in each village typology. Data source: FGD.

Figure 20 Gender perceptions of the importance of maize farming. Data source: FGD. 40

Figure 21. Perceptions of the importance of maize farming in each village typology. Data source: FGD. 41

Figure 22. Perceptions of the environmental value of the land use. Data source: FGD. 41

Figure 23. Perception of livelihood value or its importance for the land use. Data source: FGD.... 42

Figure 24. Gender roles within the marketing of each common commodity. Data source: FGD.... 44

Figure 25. Criteria used to define well-being and/or poverty based on different gender perspectives 46

Figure 26. Criteria used to define well-being and/or poverty based on villages typologies.

Data source: FGD. 46

Figure 27. Male and female perceptions of their well-being and poverty status from 1990s to the present. Data source: FGD.

Figure 28. Livelihood source and its importance for the whole community and for women based

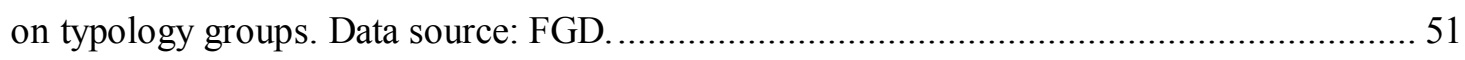

Figure 29. Gender involvement in livelihood source per village groups. Data source: FGD......... 52

Figure 30. Women's and men's activities in the household. Data source: FGD ............................ 53

Figure 31. Gender roles in selected farming system activities in whole study area. Data source: FGD.

Figure 32. The role of women in farming system activities in Southeast Sulawesi. Data source:

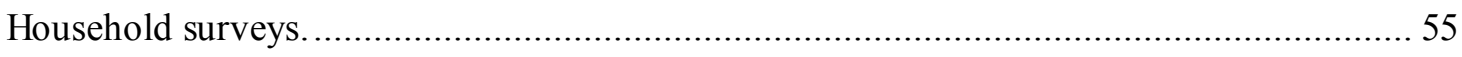

Figure 33. Gender roles in traditional agroforestr. Data source: FGD. 55 
Figure 34. Gender division of tasks in vegetable production and irrigated paddy field cultivation.

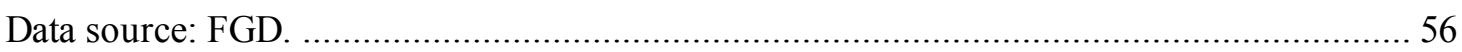

Figure 35. Gender division of tasks in forest. Data source: FGD. ............................................. 57

Figure 36. Current land tenure status in Southeast Sulawesi. Data source: Janudianto 2013 .......... 58

Figure 37. Livelihood and environment functions of each land-use system from male and female

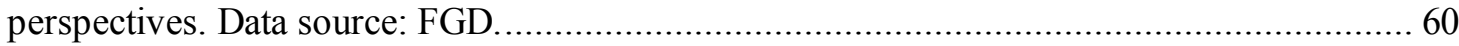

Figure 38. Livelihood and environment functions of each land-use system based on village

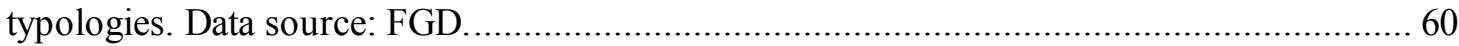

Figure 39. Gender perceptions of the importance of mixed-garden systems. Data source: FGD. ... 61

Figure 40. Perceptions of the value of mixed-gardens in each village typology.

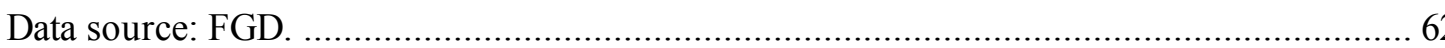

Figure 41. Gendered perceptions of the value of irrigated paddy fields. Data source: FGD........... 63

Figure 42. Perceptions of environmental value of the land us. Data source: FGD. ........................ 63

Figure 43. Perceptions of livelihood values of land use. Data source: FGD. ................................. 64

Figure 44. Gender roles in the marketing of common commodities. Data source: FGD. ............... 65

Figure 45. Criteria use to define well-being and/or poverty based on gender perspectives.

Data source: FGD

Figure 46. Poverty and/or well-being criteria as perceived by the local community per village typology groups. Data source: FGD

Figure 47. Male and female perceptions in villages within Group B regarding their well-being and poverty status from 1990s to present. Data source: FGD. 68

Figure 48. Male and female perceptions in South Sulawesi and villages within Group A regarding their well-being and poverty status from 1990s to present. Data source: FGD

Figure 49. Male and female perceptions in the villages within Group C (Tasahea) and Group D (UPT Asinoa) regarding their well-being and poverty status from 1990s to present.

Data source: FGD. 70 


\section{List of tables}

Table 1. Village typologies and detail of information from focus group discussions held in South

Sulawesi

4

Table 2. Village typologies and detailed information from focus group discussions held in

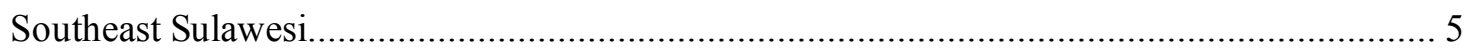

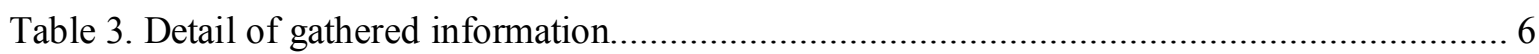

Table 4. Detail of indicators within gender development index (GDI) ...................................... 14

Table 5. Detail of indicators within gender empowerment index/measurements (GEM) ............... 16

Table 6. Livelihood source and its importance for the whole community, and for women, in each

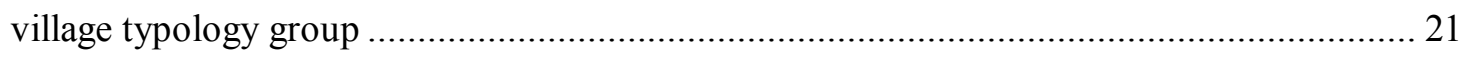

Table 7. The role of women in farming system activities in South Sulawesi ................................ 29

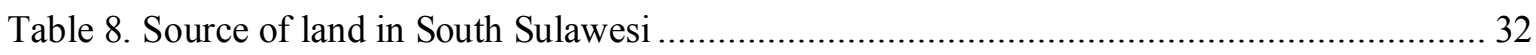

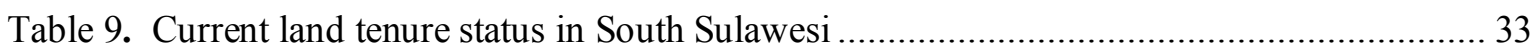

Table 10. Land holding status in surveyed villages in South Sulawesi........................................ 33

Table 11. Livelihood source and its importance for a whole community and for women based on

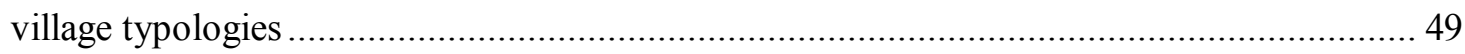

Table 12. Land holdings in surveyed villages in Southeast Sulawesi .......................................... 58 


\section{Acronyms}

AgFor $\quad$ Agroforest and Forestry

BPS Biro Pusat Statistik/Statistics Bureau

GDI Gender Development Index

GEI Gender Empowerment Index

HDI Human Development Index

TKI Tenaga Kerja Indonesia/Indonesian Labour Force

FGD Focus Group Discussion 


\section{Introduction}

\section{Why gender?}

Interrelations between men and women, and the way in which cultural and social aspects influence these relations are always topical and widely debated. Concepts of equity, equality, marginalization, and subordination are relevant to this discussion in relation to matters of social inclusion in development programmes due to institutional and power frameworks (Cornwall 2007, Sachs 1996), and development paradigms (Mosse 1993). These concepts extend to issues of visibility and value within natural resource management in rural communities.

The Gender in Agriculture Sourcebook, published by the World Bank, the Food and Agriculture Organization of the United Nations, and the International Fund for Agricultural Development, lists women as contributing $50 \%$ of family income, but their value as income earners as not recognized and under-acknowledged in their communities (IFAD 2009). Furthermore their contribution of providing good nutrition for their children and establishing family food security (Kennedy and Peters 1988, Quisumbing et al 1995), were not valued as productive but simply as obligations within their family structures (Dankelman and Davidson 1988, Quisumbing et al 1995). Women were also known as environment caretakers (Dankelman and Davidson 1988, Shiva 1988) but in many cases this role is ignored. In agricultural and agroforestry sectors, research indicates that production would increase $10-20 \%$ if women's roles in farm inputs and labour were appreciated through proper access to education and other resources (Boserup 1970, Rocheleau 1991, Quisumbing and Pandolfelli 2010). Links between gender and the environment demonstrate that men and women have different experiences and strategies in addressing environmental problems, and how they also generate knowledge about environmental changes. Therefore, taking into account the differences between women and men is necessary in the course of designing and implementing a development programme. This paper intends to focus on that difference in term of people's livelihood and land that will support agroforestry productions. Gender as used in this paper is viewed as relational in which involve men and women interaction and structured through norms and institutions. Those relations emphasis on an equality roles, access to resource, decision making process, also benefit and advantage they gained. Moreover, gender is a highly relevant issue within the Agroforestry and Forestry in Sulawesi: Linking Knowledge with Action project (the 'AgFor Sulawesi project'), therefore a study on gender was 
urgently required, to both understand the overall gender issues in Sulawesi, and also to develop criteria and indicators for project implementation. While defining quantitative indicators for the project was not difficult, defining qualitative indicators was more complicated as it required local consultation with community, and consideration of site-specific cultural and social structures.

\section{Research question}

This gender study was implemented as part of the larger Assessing Community Livelihood Systems on Linking Knowledge to Action Program in Sulawesi, designed to study general characteristics of types of livelihoods in the community, local farming systems and existing land-use systems in the area, based on community perspectives. In this study, livelihood refers to people and their source of livelihood, as well as the relationship of people with the environment. Studying land-use systems and related practices was useful to portray previous and current conditions of each land use, and to predict conditions for the future. Profitability analysis provided good understanding of the costs and benefits that people receive from their land, and from related products from other sources of livelihood. As the project intervention focuses on enhancing local people's livelihood through improved access to knowledge and skills, extension services were crucial to support the implementation, in particular at the preliminary stage, to ensure that extension support was relevant to the needs and priorities of people.

This study focuses on basic information regarding gender aspects, covering issues of gender roles, needs, access and control to natural resources, as well as other issues related to the practical and strategic needs of gender. As the early stages of development program, this survey is also important in order to develop criteria and indicators to monitor the program in regards to gender issues. The program was planned considering the different experiences, aspirations, needs and problems of men and women.

Therefore, the questions that might be important to answer are:

- Practical implications of the different roles of men and women.

- Practical implications of different access to and control of resources and benefits.

- How the program can accommodate differences between men and women in term of roles and relations.

- Strategic capacity of the project to support the manifestation of gender equality.

- In the longer term, how the project can contribute towards achieving gender equality. 


\section{Research objectives}

- Identify gender relations in regards to equality and equity, and the factors that would allow the development of recommendation strategies to better integrate women into activities of natural resource management.

- Identify criteria and indicators to measure the achievement of gender participation in natural resource management (including gender roles in plant domestication, farm production and marketing).

\section{Methodology}

As part of the AgFor Sulawesi project assessment of community livelihood systems, the data acquisition methodology for gender assessment was designed in-line with other activities. The methodology was implemented in South Sulawesi in early March 2012 and Southeast Sulawesi in early April 2012.

\section{Site selection}

In order to capture general characteristics of each AgFor Sulawesi project site in South and Southeast Sulawesi, group typologies were developed during the field trip after the inception meeting in Makassar, held on 25 January 2012. The typologies in South Sulawesi were based on physical conditions that had lead to different main land-use activities and farming practices within each area, and also took into consideration the administrative boundary of each district. The list of typologies for South Sulawesi are presented in Table 1. 
Table 1. Village typologies and detail of information from focus group discussions held in South Sulawesi

\begin{tabular}{|c|c|c|c|c|c|}
\hline & $\begin{array}{l}\text { Degraded land } \\
\text { with annual } \\
\text { crops }\end{array}$ & $\begin{array}{c}\text { Agroforestry } \\
\text { system (cacao, } \\
\text { coffee, cloves) }\end{array}$ & $\begin{array}{l}\text { Agroforestry } \\
\text { system (cacao, } \\
\text { coffee, cloves) }\end{array}$ & $\begin{array}{l}\text { Timber-based } \\
\text { system }\end{array}$ & Total \\
\hline & $A$ & $\mathrm{~B}$ & $\mathrm{C}$ & $\mathrm{D}$ & \\
\hline Districts & Bantaeng & Bantaeng & Bulukumba & Bulukumba & \\
\hline List of villages & $\begin{array}{l}\text { Onto, Kayuloe, } \\
\text { Bonto Bulaeng, } \\
\text { Bonto Karaeng, } \\
\text { Pabumbungan }\end{array}$ & $\begin{array}{l}\text { Campaga, Labbo, } \\
\text { Pattaneteang, } \\
\text { Kampala }\end{array}$ & $\begin{array}{l}\text { Borong Rappoa, } \\
\text { Balang Pesoang, } \\
\text { Batu Karopa, } \\
\text { Kahayya, } \\
\text { Bangkeng Bukit }\end{array}$ & $\begin{array}{l}\text { Karassing, } \\
\text { Tugondeng, } \\
\text { Tana Towa, } \\
\text { Tanah Beru }\end{array}$ & \\
\hline $\begin{array}{l}\text { Mini-workshop } \\
\text { or group } \\
\text { discussions }\end{array}$ & $\begin{array}{l}\text { Kayu Loe } \\
\text { Bonto Karaeng }\end{array}$ & $\begin{array}{l}\text { Pattaneteang } \\
\text { Campaga }\end{array}$ & $\begin{array}{l}\text { Borong Rappoa } \\
\text { Balang Pesoang }\end{array}$ & $\begin{array}{l}\text { Tugondeng } \\
\text { Tana Towa }\end{array}$ & 8 discussions \\
\hline $\begin{array}{l}\text { Household } \\
\text { interviews }\end{array}$ & 30 & 30 & 30 & 30 & 120 households \\
\hline
\end{tabular}

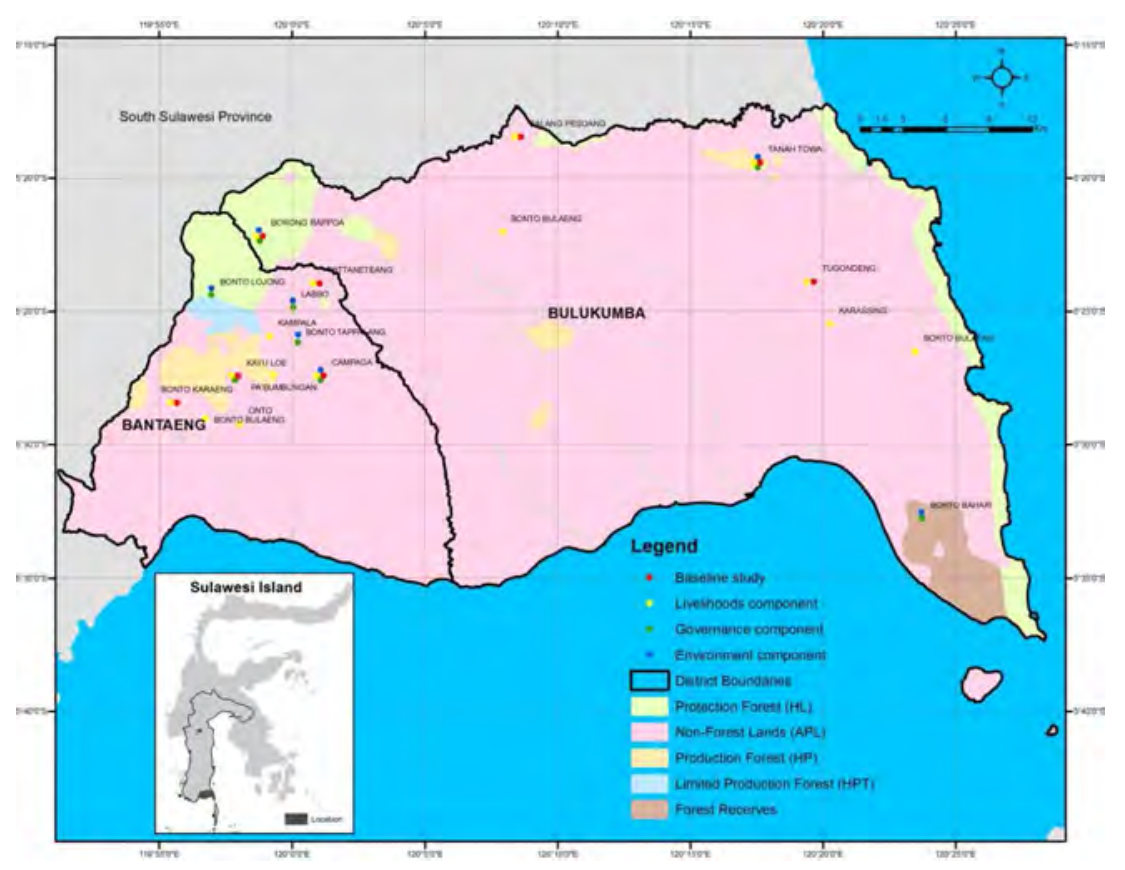

Figure 1. Location of baseline study in South Sulawesi

Differing from South Sulawesi, defining the community typologies in Southeast Sulawesi province took into consideration migration issues as illustrated in Table 2. Livelihood aspects of Southeast Sulawesi people were found to be closely related to population dynamics resulting from history and migration. People with different ethnic backgrounds, native people and immigrants were found to have different livelihood sources and strategies. 
Table 2. Village typologies and detailed information from focus group discussions held in Southeast Sulawesi

\begin{tabular}{|c|c|c|c|c|c|}
\hline Village type & Local villages & $\begin{array}{l}\text { Local and long } \\
\text { establishment } \\
\text { migrant/ transmigrant }\end{array}$ & $\begin{array}{l}\text { Long } \\
\text { establishment } \\
\text { migrant/ } \\
\text { transmigrant }\end{array}$ & $\begin{array}{c}\text { Recent } \\
\text { migrant/ } \\
\text { transmigrant } \\
\text { villages }\end{array}$ & Total \\
\hline Districts & $\begin{array}{l}\text { Konawe, } \\
\text { Kolaka }\end{array}$ & Konawe & Kolaka & Konawe & \\
\hline Group & A & B & C & $\mathrm{D}$ & \\
\hline $\begin{array}{l}\text { Group } \\
\text { discussion } \\
\text { and number of } \\
\text { discussions } \\
\end{array}$ & $\begin{array}{l}\text { Ambondiaa, } \\
\text { Lamunde, } \\
\text { Simbune, } \\
\text { Taosu (4) } \\
\end{array}$ & $\begin{array}{l}\text { Anggawo, Wonua Hoa } \\
\text { (local villagers), Wonua } \\
\text { Hoa (migrant), } \\
\text { Lawonua (4) }\end{array}$ & Tasahea (1) & $\begin{array}{l}\text { UPT Asinua } \\
\text { Jaya (1) }\end{array}$ & $\begin{array}{l}10 \\
\text { discussion } \\
\text { in } 9 \text { villages }\end{array}$ \\
\hline $\begin{array}{l}\text { Household } \\
\text { interview and } \\
\text { sample } \\
\text { number }\end{array}$ & $\begin{array}{l}\text { Ambondiaa } \\
(30) \\
\text { Simbune }(30)\end{array}$ & $\begin{array}{l}\text { Wonua Hoa (30) } \\
\text { Lawonua (30) }\end{array}$ & Tasahea (30) & Lalobite (30) & $\begin{array}{l}180 \\
\text { households }\end{array}$ \\
\hline
\end{tabular}

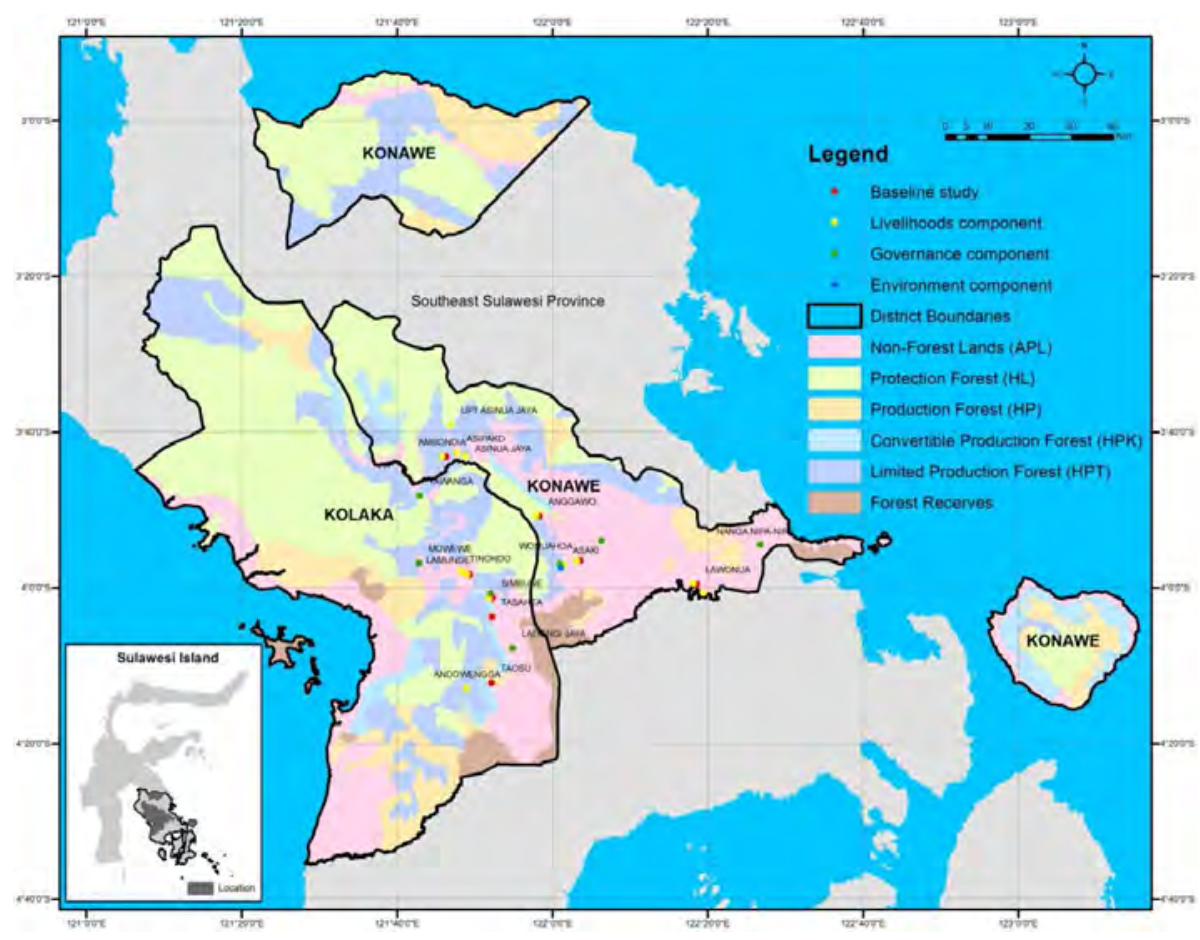

Figure 2. Location of baseline study in Southeast Sulawesi

\section{Data collection and analysis}

In order to achieve the objectives, gender analysis used was adapted from the Harvard Analytical Framework and the Moser Gender Planning Framework. The Harvard framework was employed to enable us to clearly capture methods of making women's roles and work visible (Overholt et al 1985, Rao et al 1991) This tool is also suitable to be implemented within a baseline survey prior to project 
implementation. This framework allows a portrayal of the real condition and so it is very important in order to develop criteria and indicators for assessing the situation as registering any difference before and after the project implementation. Together with Moser framework (Moser 1993), this tool can also develop clear guidance for strategic gender needs. Descriptive statistic analysis enriched the captured information regarding gender access and control.

Data collection employed both qualitative and quantitative approaches closely related to the research question. The range of data collected was implemented based on consideration of the methods best able to address detailed questioning. The detailed research questions and methods are described in Table 3.

The primary data collection methods employed were full-day mini-workshops or group discussions with village representatives. Separate discussions were held with female and male groups, using the same set of questions to compare the different points of view. Household surveys were conducted using descriptive statistics to capture current situations. Some individual interviews were undertaken to gain general views of the village and community conditions. Data from Badan Pusat Statistik (Statistics Bureau in Indonesia) and selected reports about the Human Development Index (HDI), Gender Development Index (GDI) and Gender Empowerment Index (GEI) were used to illustrate how gender issues at district and provincial levels were situated.

Table 3. Detail of gathered information

\begin{tabular}{|c|c|c|}
\hline Category & Information & Data acquisition method \\
\hline Household members & $\begin{array}{l}\text { Male-headed household, female-headed household Who } \\
\text { stays in the house or migrates to other locations (permanent or } \\
\text { temporary, destination, what they do), remittances. }\end{array}$ & $\begin{array}{l}\text { Livelihood household } \\
\text { questionnaire (Livelihood HH Q) }\end{array}$ \\
\hline $\begin{array}{l}\text { Village resources } \\
\text { map }\end{array}$ & $\begin{array}{l}\text { House and land use, abandoned land, fruit trees as marketed } \\
\text { products, animal grazed land, firewood collection, non-timber } \\
\text { forest products, other related farming systems, resources } \\
\text { related to household and community, locations women have } \\
\text { larger roles and access. }\end{array}$ & $\begin{array}{l}\text { Focus group discussion (FGD) } \\
\text { (resource mapping) } \\
\text { In-depth interview }\end{array}$ \\
\hline $\begin{array}{l}\text { Household resource } \\
\text { map }\end{array}$ & $\begin{array}{l}\text { House and land use, animals, trees, firewood locations, other } \\
\text { farming practices. }\end{array}$ & $\begin{array}{l}\text { Case study, in-depth interview } \\
\text { Livelihood HHQ }\end{array}$ \\
\hline Household asset & House, land and trees (who owns/controls). & Livelihood $\mathrm{HH} Q$ \\
\hline \multirow{3}{*}{$\begin{array}{l}\text { Household and } \\
\text { community activity } \\
\text { over a year }\end{array}$} & $\begin{array}{l}\text { Identify the productive/crisis periods, and detail activities of } \\
\text { livelihood systems in each period. }\end{array}$ & \\
\hline & $\begin{array}{l}\text { Who is more vulnerable in terms of crisis and who is more } \\
\text { productive? }\end{array}$ & $\begin{array}{l}\text { FGD (seasonal calendar and } \\
\text { activities calendar) }\end{array}$ \\
\hline & $\begin{array}{l}\text { Basic information on gender-based division of labour and } \\
\text { responsibilities in livelihood systems and resource } \\
\text { management. }\end{array}$ & Gender HH Q \\
\hline
\end{tabular}




\begin{tabular}{|c|c|c|}
\hline $\begin{array}{l}\text { Men and women's } \\
\text { time use }\end{array}$ & $\begin{array}{l}\text { Describe how women and men spend their time in a day on } \\
\text { regular basis (undertaking farming, domestic tasks, and } \\
\text { personal activities). }\end{array}$ & $\begin{array}{l}\text { In-depth interview (case study) } \\
\text { FGD (activities calendar) }\end{array}$ \\
\hline $\begin{array}{l}\text { Men and women's } \\
\text { perceptions of land- } \\
\text { use system }\end{array}$ & $\begin{array}{l}\text { Describe the benefit of each existing land use from the men } \\
\text { and women's perspectives and how it differs. }\end{array}$ & $\begin{array}{l}\text { Focus group discussion and } \\
\text { pebble games }\end{array}$ \\
\hline $\begin{array}{l}\text { Division of labour } \\
\text { (women only, mostly } \\
\text { women, women and } \\
\text { men equally, mostly } \\
\text { men, men only) }\end{array}$ & $\begin{array}{l}\text { In each farming system or land-use system Land } \\
\text { preparation, nursery, sowing, weeding, fertilizer application, } \\
\text { pesticide application, irrigation, harvest, pre-harvest } \\
\text { processing, transport, marketing. }\end{array}$ & $\begin{array}{l}\text { FGD } \\
\text { Livelihood HHQ } \\
\text { In-depth interview }\end{array}$ \\
\hline $\begin{array}{l}\text { Men and women's } \\
\text { perceptions of } \\
\text { vegetation }\end{array}$ & $\begin{array}{l}\text { Describe types of trees/other vegetation with close links to } \\
\text { women and how men and women view the importance of them } \\
\text { Identify women's preference for various tree species } \\
\text { (marketable or trees for subsistence needs). }\end{array}$ & $\begin{array}{l}\text { Focus group discussion and } \\
\text { pebble games }\end{array}$ \\
\hline \multirow{2}{*}{$\begin{array}{l}\text { Access of men and } \\
\text { women's in } \\
\text { marketing of natural } \\
\text { resource }\end{array}$} & $\begin{array}{l}\text { Describe differences between men and women in marketing of } \\
\text { each product-latex, coffee, cocoa, other products. }\end{array}$ & Livelihood HHQ \\
\hline & Market chain of farm products_-how women are involved. & In-depth interview \\
\hline \multirow[b]{2}{*}{$\begin{array}{l}\text { Men and women's } \\
\text { roles in farming }\end{array}$} & Women's participation in farming. & Livelihood $\mathrm{HH} \mathrm{Q}$ \\
\hline & $\begin{array}{l}\text { Does the group enhance female access to resources? } \\
\text { Institutional capability of the groups to support and protect } \\
\text { women during the process. }\end{array}$ & In-depth interview \\
\hline $\begin{array}{l}\text { Men and women's } \\
\text { roles in community } \\
\text { work }\end{array}$ & $\begin{array}{l}\text { Describe how men and women are involved in community } \\
\text { activities_-praying groups, artisan, other activities. }\end{array}$ & $\begin{array}{l}\text { Livelihood } \mathrm{HHQ} \\
\text { In-depth interview }\end{array}$ \\
\hline
\end{tabular}

\section{Focus group discussions}

A full day mini-workshop or focus group discussion was held in each selected village with participants comprised of invited villagers and key people indicated by leaders of the village prior to the discussions. The aim was to gain basic information about: land use and sources of livelihood history, demography and migration patterns, land management practices, poverty, select information related to training, extension and village organization, marketing practices, sources of and access to planting materials, communication, and gender roles within natural resource management. They were implemented utilizing participatory principles and applied triangulation processes from multiple sources of information. This information was consolidated within the discussions.

Mini-workshops or group-based interviews usually started at 9 a.m. and ended at 4 p.m. In each village, the participants were divided into three different groups consisting of 4-8 farmers in average. The first group consisted of mostly male participants and discussed: issues of land use, history of livelihood sources, land management practices demography and migration. The second group consisted of only male participants and discussed: gender roles in land management, communication, 
village institutions, gender perceptions of land use, values, and poverty, and basic information about their needs for extension. The third group used the same set of questions as the second group, but consisted of only female participants. Therefore, the total number of participants was an average of 24 farmers. Discussions were held in village offices, or in houses belonging to local leaders. Eight full day mini-workshops were held in South Sulawesi in eight villages, four in Bantaeng and four in Bulukumba. In Southeast Sulawesi, there were 10 full day mini-workshops held in nine villages, five in Konawe and four in Kolaka.

\section{Household interviews}

Information was collected from 30 households of random stratification per village, from four sampled villages in South Sulawesi (Table 1) and Southeast Sulawesi (Table 2). As much as possible, both the husband and wife from each household were interviewed together. Data was sought on family characteristics including: household demography (house condition, schooling of the household head, wife and children, number of family members, age of household head, age of household members, number of men/women in household, ethnicity of household head) history of land use (slope of land, location of land, walking time from home to the field, years of land acquisition, status of land management, how to access the land and how to own the land, where/who land was gained from, current land tenure status, current land use, land use before acquisition, land use one year after acquisition and previous land use); plot size for all crops; costs; hire labour use; and revenue of land use types, such as cacao agroforest, mixed-gardens and rice paddy fields.

\section{General overview of the sites}

\section{South Sulawesi}

South Sulawesi, the province in the southern part of Sulawesi Island, consists of 20 districts and three municipalities with a total area of $45,764 \mathrm{~km}^{2}$. With forested area of more than $57 \%$, wet paddy system $9 \%$, wetland (swampy area) more than $10 \%$, and agriculture nearly $10 \%$, the province is famous for being the first producer of paddy and other food crops including maize, cassava, sweet potato and peanut in the eastern part of Indonesia. Plantation crops common in South Sulawesi are cacao, coconut, clove and coffee. These crops are mainly managed on smallholdings rather than a large-scale. 
Bantaeng and Bulukumba are two districts selected as AgFor Sulawesi project sites. In 2007, Bantaeng and Bulukumba District were respectively the second and fifth highest producers of maize as a food crop, together with Gowa, Jeneponto, and Bone districts as the five highest producers. In term of paddy production, alhough Bantaeng was not the highest, their production was still above the average of South Sulawesi production (5.01 over 4.7), while Bulukumba was slightly lower than the average (4.68), (Sulawesi Selatan in Figures, 2007).

In South Sulawesi-Bone, Luwu, Luwu Timur, Luwu Utara, and Pinrang are the five districts with large areas of cacao production (more than $20000 \mathrm{ha}$ ). As previously stated, this large area of cacao production is mainly operated on smallholder-scale (265 985 ha; and private scale 4075 ha). Cacao production in the Bantaeng and Bulukumba districts covers 5377 and 7456 ha respectively, with productivity in 2010 in Bulukumba $4626 \mathrm{t}$ and in Bantaeng 2157.

http://regionalinvestment.bkpm.go.id/newsipid/id/commodityarea.php?ia=73\&ic=3

Clove production in South Sulawesi is mainly from smallholder plantations of mixed-garden systems covering 44524 ha. In 2010 the total clove production in South Sulawesi was 16385 t, with Bulukumba producing 5.2\% and Bantaeng $1.9 \%$ of the total. http://regionalinvestment.bkpm.go.id/newsipid/id/commodityarea.php?ia=73\&ic=85 In 2010 the total coffee production in South Sulawesi was 36554 t, of this Bulukumba produced $11.3 \%$ and Bantaeng, $4.38 \%$. The total area for coffee production in South Sulawesi managed by smallholders is currently 70412 ha, in Bantaeng 3800 ha, and in Bulukumba it is 5179 ha. http://regionalinvestment.bkpm.go.id/newsipid/id/commodityarea.php?ic=62\&ia=73

\section{Ethnic groups}

Sulawesi, formerly known as Celebes, is comprised of hundreds of ethnic groups. As indicated in Ethnologue (Lewis 2012) (http://www.ethnologue.com/show_country.asp?name=IDL) it has 114 local dialects. South Sulawesi is inhabited by five main ethnic groups: Bugis, Makassar, Toraja, Mandar and Duri. Bugis and Makassar are the largest ethnic communities. The majority of Makassar (Macassarese or Macassar) people are located in the southwest corner of the peninsula, mostly in the Pangkep, Maros, Gowa, Bantaeng, Jeneponto, and Takalar districts. Bugis are mainly found in the coastal swamp areas of Bulukumba, Luwu, Polewali in the Polmas district, Pasangkayu in the Mamuju district as well as in other areas in Central Sulawesi and Southeast Sulawesi, and in minor areas in Sumatra, Malaysia and Singapore. Bugis were popularly known as 'the great migrants' in many areas. Mandar are found in Majene and Polewali-Mamasa districts, a few settlements in 
Mamuju district, on the islands of Pangkep district, and at Ujung Lero near Pare-Pare. The majority of Toraja are located in Tana Toraja district with large enclaves in Luwu district, and Duri reside in Enrekang district. Ethnic groups common in Bantaeng are mostly Makassar with a minority of Bugis, and Bugis who dominate Bulukumba. This ethnic group distribution information was extracted from Lewis (2009).

\section{Gender and cultural identity}

Gender issues in South Sulawesi are widely discussed within sociology and anthropology, as they are closely linked with cultural issues. In particular, within Bugis culture, gender presents a range of interesting issues as it not only consists of men ('oroane') and women ('makkunrai'), but also other gender roles, 'calabai' (anatomical males with social roles as women), 'calalai' (anatomical females with social roles as men), and 'bissu' (anatomically male or female, but performing a combined masculine and feminine role, and are acknowledged as priests, the highest caste) (Graham 2001). Sharyn Graham, an anthropologist from Australia, examined the close links between 'siriq' (shame) and gender within the Bugis community. Women as primary symbols of family honour can only perform their status of womanhood if they embody femininity: become wives and mothers, marry heterosexually and bear children. Women who do not meet these expectations were considered as 'siri' or causing shame, and calalai, as 'other than women', The men who weren't able to perform as 'real men', were considered 'other than men', as calabai (Idrus 2003).

Bissu are Bugis priests who hold the important role of holding rituals for nobles, and taking care of sacred treasures of the kingdom. Bissu is also known as the fifth meta gender within the Bugis community, combining the feminine and masculine, therefore they accentuate a combination of these attributes. Bissu are usually associated with pre-Islamic traditions, and in 2004, when the movie The Last Bissu: sacred transvestites of I La Galigo (Grauer 2004) was produced, there were only eight Bissu left in South Sulawesi.

The gender identities illustrated above provide a cultural overview of Bugis, the main ethnicity in South Sulawesi. These gender identities are necessary to elaborate to provide a better understanding of how gender roles relate to natural resource management in the context of Bugis communities. However, our discussion within this report will only focus on the gender identities as common in other areas; men and women. 


\section{Southeast Sulawesi}

Southeast Sulawesi province lies in the southern peninsula of Sulawesi, and includes a number of small islands such as Buton and Muna, and some islets including Wowoni and Kabaen. The mainland of southeast Sulawesi is $38140 \mathrm{~km}^{2}$ and the small island area is $114876 \mathrm{~km}^{2}$. Konawe, Kolaka, Bombana are the main areas of the mainland, and Kendari is the capital city. AgFor Sulawesi projects have focused on the Konawe and Kolaka districts of the mainland.

In 2007, the agriculture sector contributed $38 \%$ of the national economic growth with cassava and corn crops, and commodities of cocoa, coffee, coconut, cloves, cashew nut, pepper and oil palm. Data from the same year showed that from an area of nearly 15000 ha, almost $240000 \mathrm{t}$ of cassava was produced, and from an area of $40975 \mathrm{ha}, 97037 \mathrm{t}$ of maize was produced. For cassava production, Konawe contributed nearly $5 \%$ of the total, while Kolaka contributed $3.3 \%$. Buton produced the highest amount of cassava with 76709 t produced from 4795 ha. The highest maize producer in southeast Sulawesi was Buton district (13 990 t), followed by Kolaka (6 454 t), Buton Utara (5 863 t), Kendari (3 569 t) and Konawe (3 297 t).

http://regionalinvestment.bkpm.go.id/newsipid/id/area.php?ia=74

Oil palm production in Southeast Sulawesi was concentrated in the Kolaka district in an area covering 21033 ha, and producing 7220 t. Cacao productivity in Southeast Sulawesi was 137833 t in 2010, with the largest area of cacao production in Kolaka (91 259 ha) and Kolaka Utara (82 206). The other districts also produced cacao but from areas less than 10000 ha. The highest production was in Kolaka Utara with 63101 t produced in 2009, and in Kolaka which produced 29297 t in 2009. In 2010, pepper production in Southeast Sulawesi was $5371 \mathrm{t}$, from a total area of 11775 ha, with approximately 99\% produced by smallholders. Konawe contributed 1317 (24.5\%) t from 3661 ha, and Konawe contributed nearly $40 \%$ of total pepper production in Southeast Sulawesi.

\section{Ethnic groups}

Southeast Sulawesi is inhabited by five main ethnic groups: Tolaki, Buton, Muna, Moronene and Bugis. The Tolaki tribe is estimated at representing $16 \%$ of the whole of Southeast Sulawesi (including the sub-ethnic group Mekongga). The Tolaki and the Moronene tribes are the two indigenous tribes who live primarily on the mainland. These five tribes are located scattered throughout Kolaka, Kolaka Utara, Kendari, Konawe, Konawe Selatan, North Konawe, and Bombana. Muna and Buton are the indigenous tribe of the islands, inhabiting the regions Muna, Buton, North Buton, Bau-Bau, Wakatobi, and the surrounding small islands. Bugis are the dominant migrants from 
South Sulawesi, and there are many other migrants from transmigration programs including ethnic Javanese, Sundanese and Balinese. Although Moronene is known as the oldest tribe in this region, Tolaki and Buton are the most prominent ethnic group (Arafah 2002).

Migrants mainly come from Java, Bali, and South Sulawesi. People from Java and Bali initially came as part of transmigration programs, followed by some spontaneous migration. Within Southeast Sulawesi, people also migrated to other areas outside the transmigration areas after they cultivated their area. Migrants from South Sulawesi moved spontaneously to gain land for cocoa cultivation. A majority of these came to the Kolaka and Konawe districts.

\section{Gender development and empowerment index}

In order to understand gender issues of equality and equity in South and Southeast Sulawesi at provincial and district levels, Human Development Index (HDI), Gender Development Index (GDI) and Gender Empowerment Measurement/Index (GEM) were analysed. HDI is a simple or composite measurement describing levels of human development. It demonstrates the progress of development of three basic human capabilities: life expectancy, education enrolment, and standard of living. GDI describes development progress for women and men, therefore it is able to explain the gap between the two genders. GDI has the same dimensions as HDI: life expectancy, education, and income, but uses an equally distributed index which disaggregates women and men. However, GDI is not specifically a measure of gender inequality. Figure 3 represents HDI and GDI in 2010 for the six areas: South Sulawesi province and the two districts (Bantaeng and Bulukumba), and Southeast Sulawesi province and the two districts (Konawe and Kolaka). 


\section{Human and Gender Development Index}

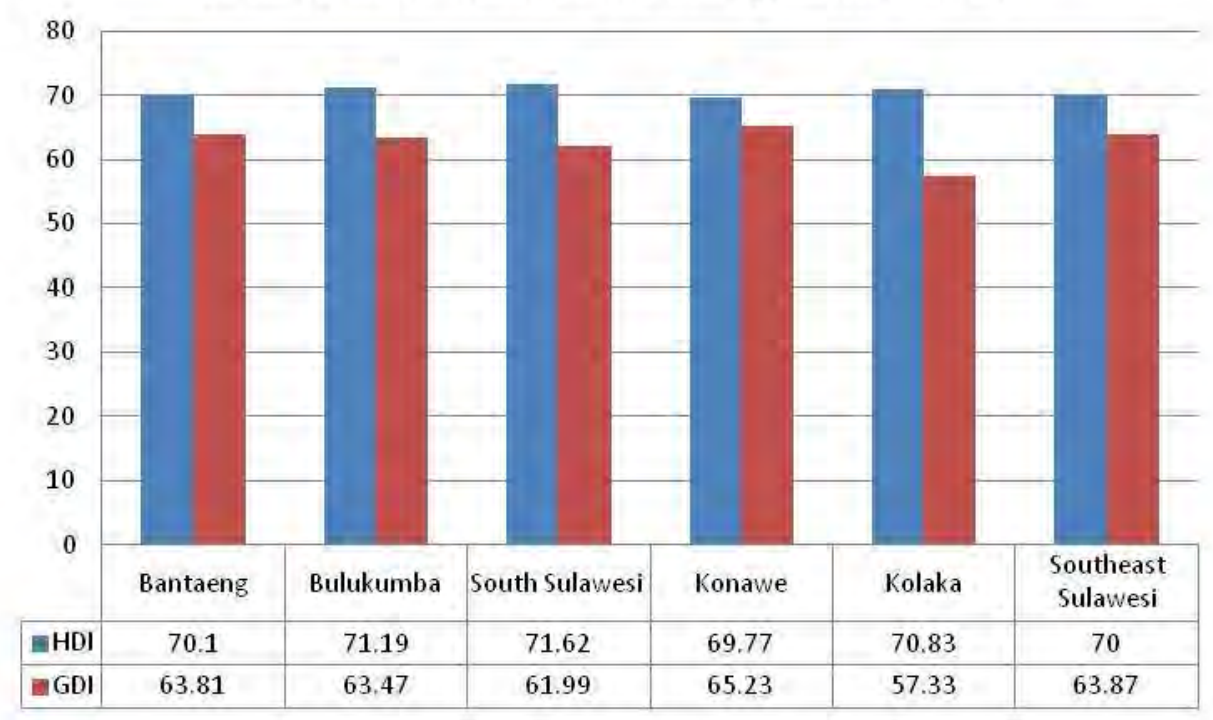

Figure 3. Human and Gender Development Index for 2010 in South Sulawesi, Bulukumba and Bantaeng districts, Southeast Sulawesi, and Konawe and Kolaka districts. (Data source: Pembangunan Manusia Berbasis

Gender Tahun 2005-2011, Corporation between BPS and Kementerian Pemberdayaan Perempuan dan Perlindungan Anak).

The HDI of South Sulawesi from 2009 to 2012 increased from 70.94 to 71.62, and the level within the national ranking in respective years decreased from 20 to 19. From 2009 to 2010, the HDI of Southeast Sulawesi increased from 69.52 to 70 , but the level within the national ranking remained the same, at 25. The increase in index from 2004 to 2012 in South Sulawesi performed higher $(0.92 \%$ in average) than in Southeast Sulawesi (0.81 in average). In 2010, the HDI level within the national ranking of Bantaeng and Bulukumba was 312 and 248 respectively, and for South Sulawesi, 18 and 12 respectively. Although Bantaeng had a lower HDI when compared with Bulukumba, the index from 2004 to 2012 had increased highly, in average an increasing index of $1.37 \%$ per year. The same situation was also seen in Southeast Sulawesi, although Konawe had a lower HDI the increase in index from 2004 to 2012 was relatively higher than Kolaka and Southeast Sulawesi.

GDI in South Sulawesi increased from 28 in 2009 to 27 in 2010, with GDI in respective years of 61.24 and 61.99. Although the rank of GDI in Southeast Sulawesi remained the same at 20, the index increased from 62.89 in 2009 to 63.87 in 2010. In 2010, the GDI rank in the national level of Konawe and Kolaka were 181 and 421 respectively. For Bantaeng the GDI the level within the national ranking was 227 and for Bulukumba it was 241. More detailed information of the GDI indicators are presented in Table 4. 
In 2012, there were 42\% provinces of Indonesia with HDI and GDI below the national level, including South and Southeast Sulawesi. HDI below national level indicates that human development is still relatively low compared to the national average. GDI below national level indicates that gender gaps are relatively high. HDI in National level were 72.27 and GDI were 67.20.

Large gaps between HDI and GDI can indicate that the current development schemes are not taking into consideration gender equality issues, therefore the development programs of government and other stakeholders must be designed to be more gender sensitive.

The gap between HDI and GDI in South and Southeast Sulawesi is relatively high, indicating that development between men and women is not yet balanced (Figure 4 and Figure 5). Men are still seen perceived as dominant in the economic sector. This can be due to either the low participation of women in economic sector, or that women's contribution is under-acknowledged. Data shows a trend in the gap between HDI and GDI rank in national level as decreasing from year to year. It indicates that gender equity is tending to increase from year to year. This could be due to the impact of some progressive development programs which are already considering gender aspects. In South Sulawesi, initially the gap between HDI and GDI in Bantaeng and Bulukumba was higher than in South Sulawesi, but it then decreased to be even lower than in South Sulawesi. This shows that development progress in Bantaeng and Bulukumba is quite progressive in reaching gender equity compared with other areas in South Sulawesi. Kolaka had the highest gap between HDI and GDI when compared with Konawe and Southeast Sulawesi, as well as with South Sulawesi, Bulukumba and Bantaeng.

Table 4. Detail of indicators within gender development index (GDI)

\begin{tabular}{|c|c|c|c|c|c|c|c|c|c|}
\hline & \multicolumn{2}{|c|}{$\begin{array}{c}\text { Life expectancy at } \\
\text { birth (years) }\end{array}$} & \multicolumn{2}{|c|}{$\begin{array}{l}\text { Literacy rate } \\
(\%)\end{array}$} & \multicolumn{2}{|c|}{$\begin{array}{c}\text { School } \\
\text { enrolment } \\
\text { ratio (years) }\end{array}$} & \multicolumn{2}{|c|}{$\begin{array}{l}\text { Contribution to } \\
\text { income }(\%)\end{array}$} & \multirow[t]{2}{*}{ GDI in 2010} \\
\hline & Men & Women & Men & Women & Men & Women & Men & Women & \\
\hline South Sulawesi & 68.08 & 72.03 & 90.85 & 85.54 & 8.14 & 7.58 & 70.86 & 29.14 & 61.99 \\
\hline Bantaeng & 71.76 & 75.52 & 82.58 & 77.75 & 6.19 & 5.78 & 66.51 & 33.49 & 63.81 \\
\hline $\begin{array}{l}\text { Southeast } \\
\text { Sulawesi }\end{array}$ & 65.88 & 69.85 & 95.88 & 89.07 & 8.51 & 7.72 & 67.83 & 32.17 & 63.87 \\
\hline
\end{tabular}


Another human development index is Gender Empowerment Index/Measure (GEM) or a composite index measuring the ability of men and women to achieve equality in terms of participation in various forms of decision making (political participation) and within economic activity (economic participation and power over economic resources). Indicators used to measure political participation were the percentage of men and women involved in parliament. The levels of women's involvement in economic activity were measured using the strategic indicators of the percentage of women as workers, managers, professionals, technicians and administrators, as well as describing their as contributions to household income, through the percentage of contribution made by women towards household income. In short, GEM consisted of three important components; political involvement, women as professionals, and women's contribution towards economic income.

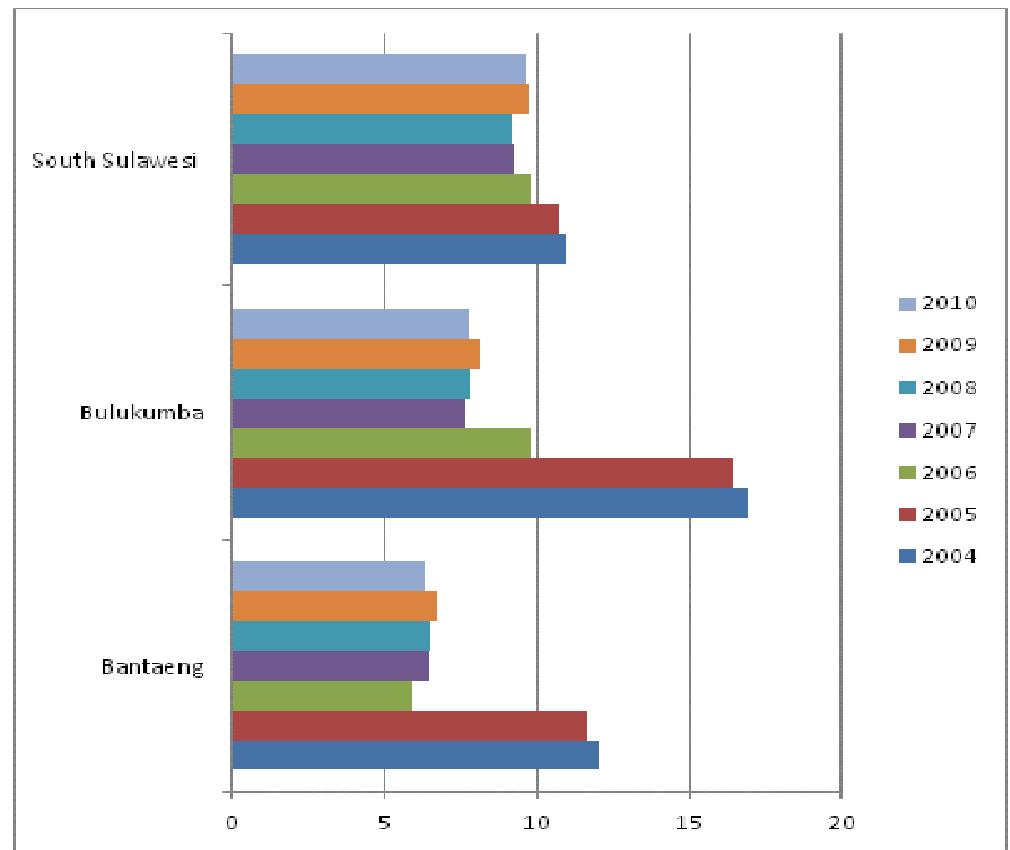

Figure 4. Gap between HDI and GDI from 2004 to 2012 in South Sulawesi, Bulukumba and Bantaeng. (Data source: Pembangunan Manusia Berbasis Gender Tahun 2005-2011, Corporation between BPS and Kementerian Pemberdayaan Perempuan dan Perlindungan Anak) 


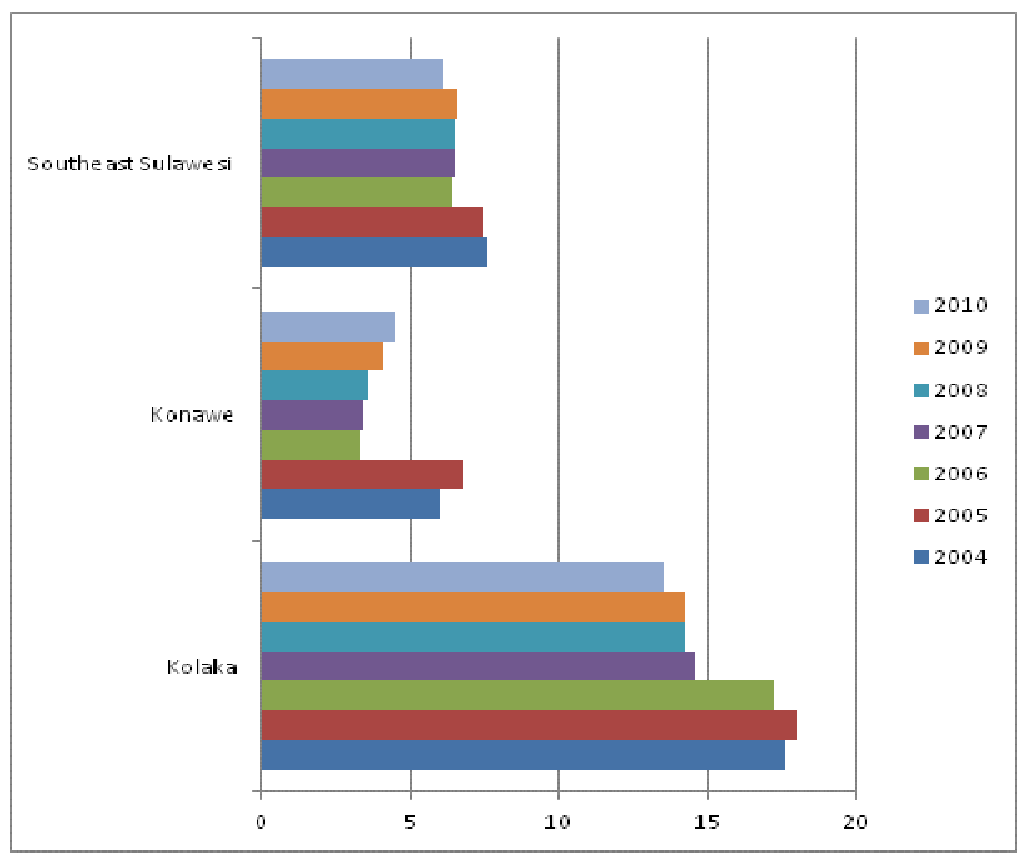

Figure 5 Gap between HDI and GDI from 2004 to 2012 in Southeast Sulawesi, Konawe and Kolaka. (Data source: Pembangunan Manusia Berbasis Gender Tahun 2005-2011, Corporation between BPS and Kementerian Pemberdayaan Perempuan dan Perlindungan Anak).

In 2010, the highest GEM was in Bantaeng, formed by the high proportion of women involved in parliaments. GEM in Bantaeng was also above the average national level, while other areas were below. The opportunity for women to be more involved equally in parliaments and other professional workplaces was very low in Kolaka, indicated by the low GEM.

Table 5. Detail of indicators within gender empowerment index/measurements (GEM)

\begin{tabular}{lcccc}
\hline & $\begin{array}{c}\text { Women within } \\
\text { parliaments (\%) }\end{array}$ & $\begin{array}{c}\text { Women as managers, } \\
\text { professionals, } \\
\text { administrators, } \\
\text { technicians (\%) }\end{array}$ & $\begin{array}{c}\text { Women's } \\
\text { contribution to } \\
\text { income (\%) }\end{array}$ & $\begin{array}{c}\text { GEM } \\
\mathbf{2 0 1 0}\end{array}$ \\
\hline South Sulawesi & 16 & 49.03 & 29.14 & 62.46 \\
\hline Bulukumba & 10 & 51.19 & 32.67 & 57.97 \\
\hline Bantaeng & 28 & 55.77 & 33.49 & 74.1 \\
\hline Southeast Sulawesi & 15.56 & 47.16 & 32.17 & 64.26 \\
\hline Konawe & 13.33 & 50.44 & 34.36 & 63.15 \\
\hline Kolaka & 14.29 & 44.98 & 22 & 57.11 \\
\hline National & 17.49 & 44.02 & 33.5 & 68.15 \\
\hline
\end{tabular}

Data source: Pembangunan Manusia Berbasis Gender Tahun 2005-2011, Corporation between BPS and Kementerian Pemberdayaan Perempuan dan Perlindungan Anak 
In order to analyse the relation between HDI, GDI and GEM, the Report of Human Development Based on Gender (2012) used the national HDI and GEM as a cut-off point. As previously stated, the HDI and GDI in four districts and two provinces of South and Southeast Sulawesi in 2010 were below the national HDI, and the GEM was also below the national level (of 68.15).

Quadrant analysis presented in Figure 6 was formulated using the gaps between HDI and GDI as an xaxis, and the GEM as a y-axis. The first quadrant was the area with HDI and GDI with low gaps, and the GEM lower than the national level. Within this category, human development was almost relatively equitable for men and women, but the level of achievement in GEM still low. The area included in this category was Konawe, which still needs to concentrate on improving the achievement of gender empowerment in parliaments and professional work in general. Interestingly, in Konawe, women's contributions within the economic sector performed the highest from all of the areas listed in Table 5.

The second quadrant is indicated by the area with high GEM and low gaps between HDI and GDI. Within all of the study areas in this research, none were categorized in this quadrant.

The third quadrant displayed gaps between HDI and GDI higher than the national levels, but GEM above the national level. Although human development within these areas was not in particular focusing on gender equity, gender empowerment was relatively better. Bantaeng has a good representation of both men and women within parliaments and professional work, and women make a strong contribution to economic income. However, these human developments have not been accompanied by equitable human development outcomes between men and women.

The fourth quadrant is inhabited with the majority study areas, South and Southeast Sulawesi at provincial level, and Bulukumba and Kolaka at district level. The areas within this quadrant should concentrate on designing a human development program that is more equitable for men and women, as well as working to improve female involvement in parliaments and professional work, and to encourage women's contribution to the economic sector. 


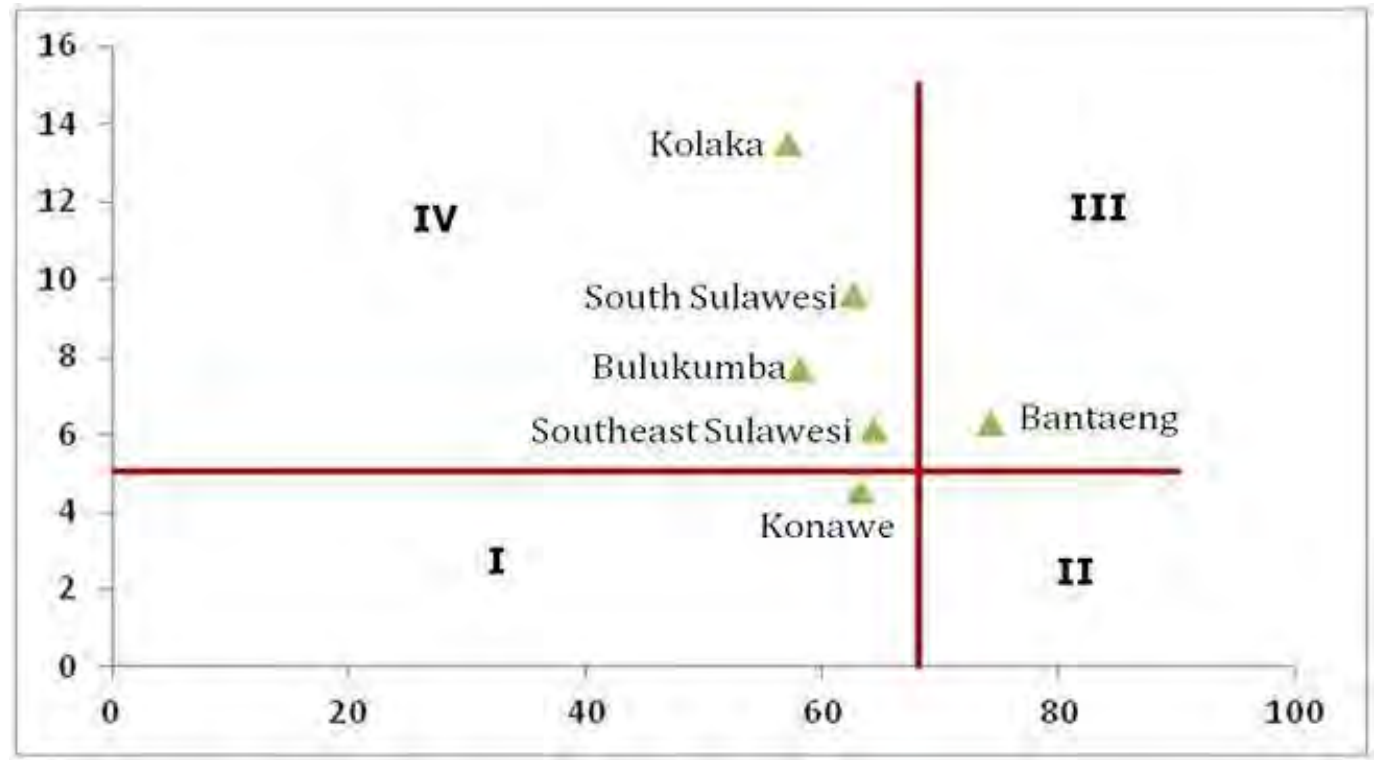

Figure 6. Quadrant analysis of gaps between HDI and GDI, and DEM. Data source: BPS and Kementrian Pemberdayaan Perempuan dan Perlindungan Anak 2012.

Pembangunan Manusia Berbasis Gender Tahun 2005-2011. 

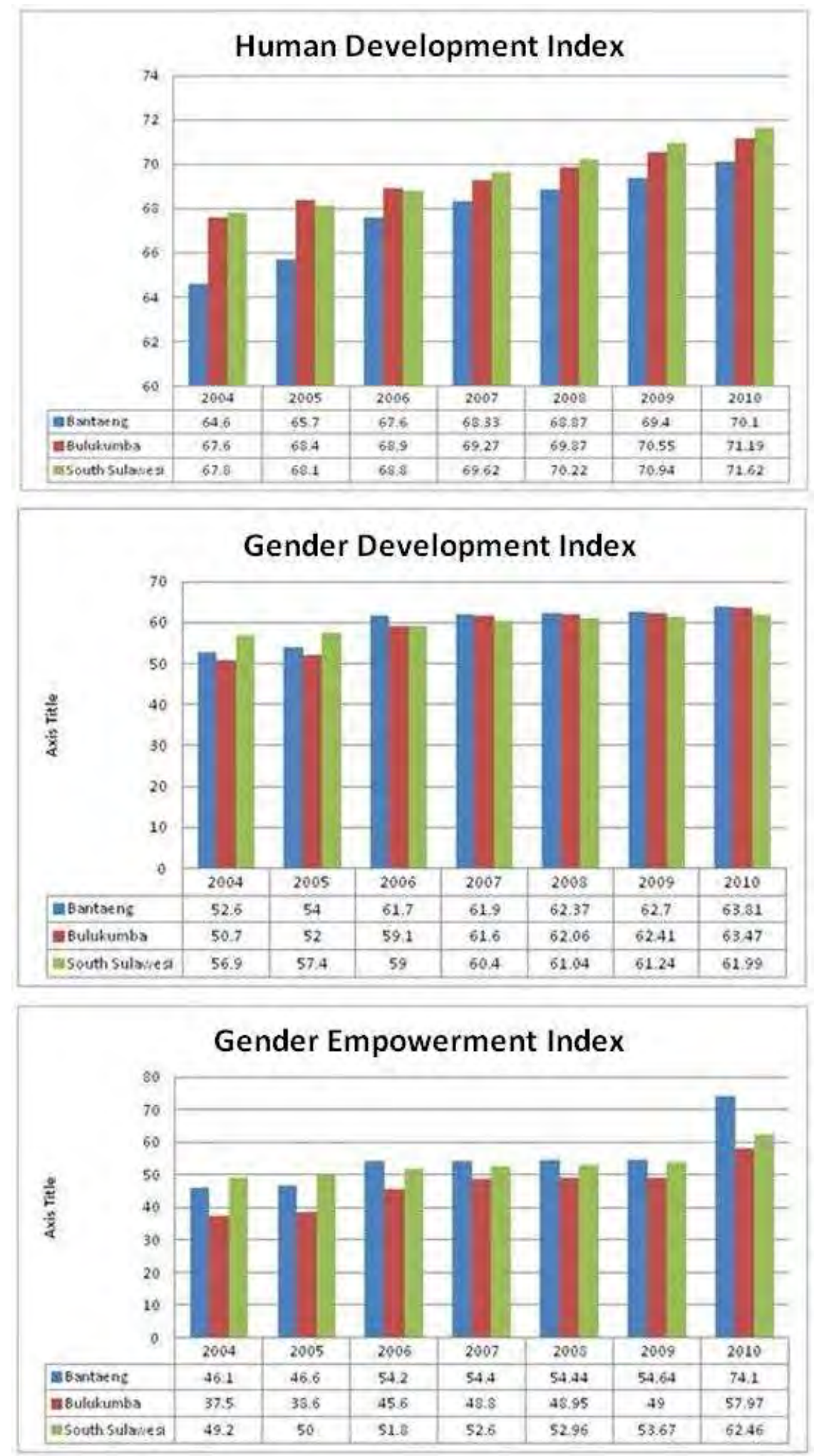

Figure 7. Human and Gender Development Index, and Gender Empowerment Index in South Sulawesi province,

Bulukumba and Bantaeng districts from 2004 to 2012. (Data source: BPS and Kementrian Pemberdayaan

Perempuan dan Perlindungan Anak 2012. Pembangunan Manusia Berbasis Gender Tahun 2005-2011). 

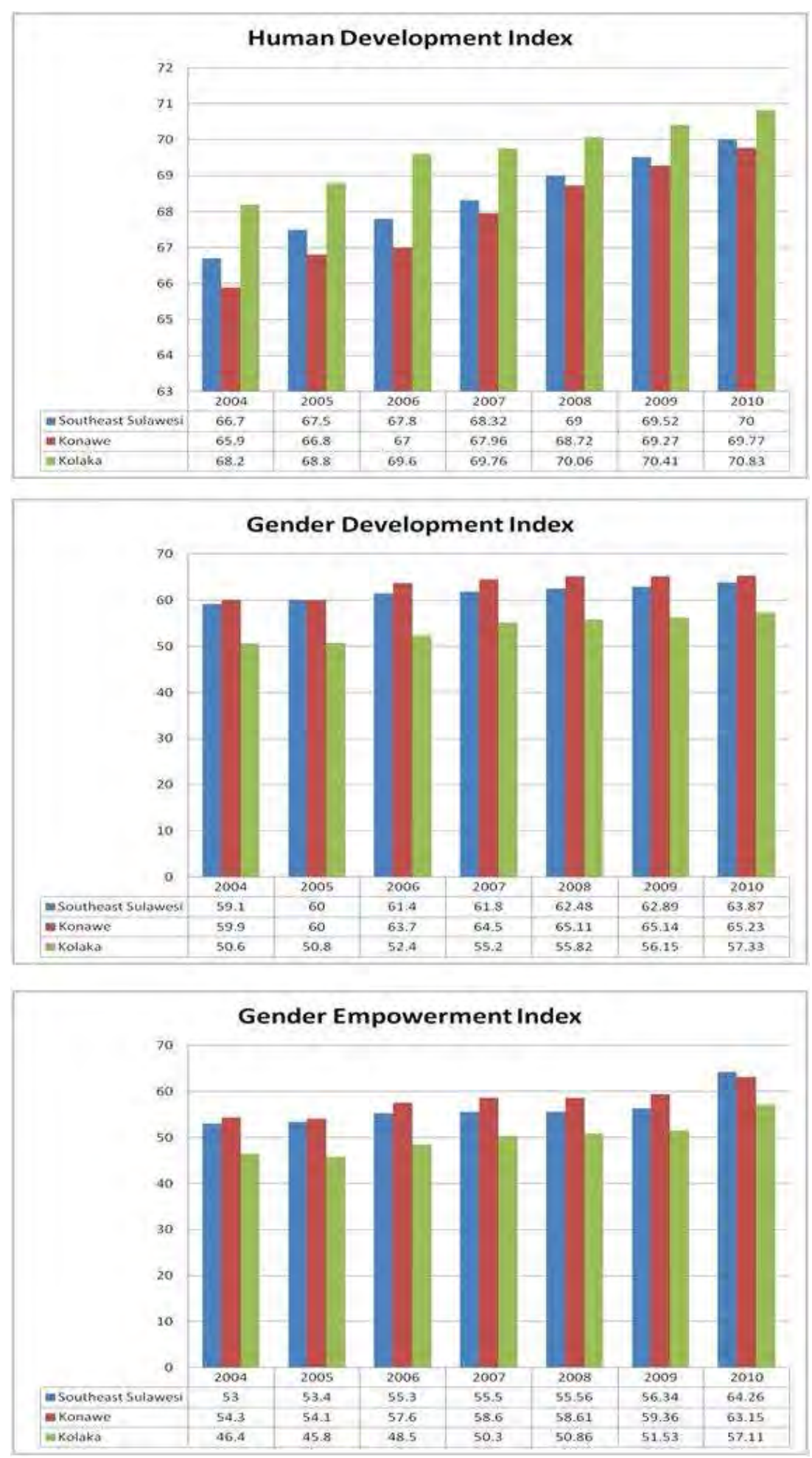

Figure 8. Human and Gender Development Index, and Gender Empowerment Index in Southeast Sulawesi,

Konawe and Kolaka districts from 2004 to 2012. Data Source: BPS and Kementrian Pemberdayaan Perempuan dan Perlindungan Anak. 2012. Pembangunan Manusia Berbasis Gender Tahun 2005-2011). 


\section{Gender, livelihood, land and management in South}

\section{Sulawesi}

\section{Gender in livelihood sources}

This section elaborates upon men and women's roles within land-based livelihood sources in rural communities. Our findings within this study explore how women are involved in natural resource management as well as in the public sector. Discussions began with the aim of ascertaining the important livelihood sources for women and men within the community. Two separate discussions with women and men were conducted to assess the livelihoods sources existing in the area, their importance for the whole community (both for women and for men as a whole), and specifically for women.

Table 6. Livelihood source and its importance for the whole community, and for women, in each village typology group

\begin{tabular}{|c|c|c|c|c|c|c|c|c|c|c|}
\hline \multirow{2}{*}{ Values for: } & \multicolumn{2}{|c|}{ A (Degraded land) } & \multicolumn{2}{|c|}{$\begin{array}{c}\text { B (Agroforestry - } \\
\text { Bantaeng) }\end{array}$} & \multicolumn{2}{|c|}{$\begin{array}{c}\text { C (Agroforestry - } \\
\text { Bulukumba) }\end{array}$} & \multicolumn{2}{|c|}{$\begin{array}{c}\text { D (Timber- } \\
\text { based system) }\end{array}$} & \multirow[t]{2}{*}{$\begin{array}{c}\text { Total } \\
\text { women }\end{array}$} & \multirow[t]{2}{*}{$\begin{array}{l}\text { Total com- } \\
\text { munity }\end{array}$} \\
\hline & Women & $\begin{array}{l}\text { Com- } \\
\text { munity }\end{array}$ & Women & $\begin{array}{l}\text { Com- } \\
\text { munity }\end{array}$ & Women & $\begin{array}{l}\text { Com- } \\
\text { munity }\end{array}$ & Women & $\begin{array}{l}\text { Com- } \\
\text { munity }\end{array}$ & & \\
\hline Mixed-garden & 7.75 & 7.08 & 7.78 & 8.80 & 8.42 & 8.42 & 6.35 & 6.05 & 7.55 & 7.54 \\
\hline $\begin{array}{l}\text { Irrigated } \\
\text { paddy field }\end{array}$ & 7.79 & 8.29 & 6.99 & 6.81 & 5.83 & 6.19 & 6.41 & 7.00 & 6.61 & 6.90 \\
\hline $\begin{array}{l}\text { Maize and } \\
\text { other crops }\end{array}$ & 7.90 & 7.90 & 6.88 & 7.16 & 6.33 & 6.33 & 5.01 & 5.41 & 6.66 & 6.83 \\
\hline Farm labour & 1.33 & 3.33 & 4.29 & 7.14 & 5.57 & 5.57 & 3.68 & 3.54 & 3.64 & 4.58 \\
\hline Tenant & 4.67 & 5.17 & 3.85 & 4.95 & 4.64 & 4.64 & 1.74 & 1.74 & 3.74 & 4.21 \\
\hline TKI & 4.10 & 4.10 & 3.81 & 2.98 & 4.46 & 3.71 & 3.60 & 4.83 & 4.00 & 3.95 \\
\hline $\begin{array}{l}\text { Non-timber } \\
\text { forest }\end{array}$ & 2.00 & 3.36 & 4.05 & 2.52 & 2.00 & 1.00 & & & 3.37 & 2.54 \\
\hline $\begin{array}{l}\text { Forest } \\
\text { (timber) }\end{array}$ & 4.00 & 2.00 & 0.63 & 0.63 & 3.00 & 2.00 & 4.44 & 6.67 & 2.54 & 2.38 \\
\hline
\end{tabular}

Data source: FGD.

One of the important results is illustrated in Table 6. Mixed-gardens, irrigated paddy fields and horticulture plots (maize and other crops) are the primary important land-based livelihood sources both for the community, and for women in this study location. Off-farm work remains important in 
every area, consisting of a range of activities: primarily farm labour (labour on individual farms), some company labour (labour on state or company plantations or agricultural systems), and other nonfarm activities such as handyman/building, transportation services, and others.

Mixed-gardens had high importance as a livelihood source as it provides not only a source of income but also meets subsistence need. A majority of the community practiced a mixed-garden system although the main commodity in each system was not always the same- usually coffee, cacao, or clove-based. Horticulture plots were usually dominated by maize production and one main vegetation, such as long bean or spinach. People without land, were able to cultivate paddy and horticulture with a tenancy system or sharecropping/'deelbouw' (locally called 'tesang' or 'teseng') arrangement. Sharecropping is usually structured with the rate of $50 \%$ to each of the two parties. Tenaga Kerja Indonesia ('TKI', Indonesian work force) or labour work abroad was also rated as important for both the whole community and for women. Due to harvest failure there has been an increase in community members working abroad over the past three years. Although it was argued that most people do not prefer to work abroad, the increasing numbers of TKI each year have meant that this livelihood source has become more important for the community.

Within group A (degraded land), in the Kayu Loe and Bonto Karaeng villages in Bantaeng district, it was found that the most important livelihood source for women was horticulture, followed by irrigated paddy field, mixed-garden tenancy systems, working abroad as a TKI, income from the forest, and finally farm labour. Horticulture production (maize and other crops) in Kayu Loe and Bonto Karaeng is mainly maize cultivation, used for source income and also for subsistence need. Maize (locally called 'jagung kuning') has been cultivated by the community for many years. The types of soil in the area are the main reason for the local community's preference for cultivating maize. For the community, irrigated paddy field was more important compared with horticulture cultivation. Interestingly, women described timber from the forest as being more important compared with non-timber products, however the wider community had different opinions regarding this. Mixed-gardens were an important livelihood source system for the community and women in Group B (agroforest system in Bantaeng), Pattaneteang and Campaga villages. Horticulture, farm labour and irrigated paddy field were the livelihood sources important for the whole community, although offfarm labour was also very important. For women, after mixed-garden, irrigated paddy field was rated the second, as they described paddy as very important for their consumption. Differing from the condition of Group A (degraded land) who depend upon maize production for their staple food and 
source income, paddy remains important particularly for women in these two villages, although there is also a poor element of the community who depend only on maize.

The physical condition in Group C (agroforest system in Bulukumba) was relatively similar to Group B (agroforest system in Bantaeng). The social condition is also similar, with the community dominated by Makassar people. However, in terms of the importance of horticulture (maize and other crops) and irrigated paddy fields compared with farm labour, people in Group C described horticulture as more important than farm labour both for the wider community as well as specifically for women. While the importance of working abroad for the wider community in the two villages of Group C and B was not important, for women, the income from TKI was rated as important.

Discussions with men's and women's groups across the whole study areas indicated that the most important land-based livelihood source for women was mixed-garden, irrigated paddy field, and horticulture. Figure 9 shows different perceptions of how men and women viewed the importance of land-based livelihood sources for women for each village typology. In Group A (degraded land), men perceived that both mixed-garden and irrigated paddy field systems have the same level of importance for women, but women perceived that horticulture (maize and other crops) were more important. Women considered horticulture important as it met their responsibilities to fulfil food needs for their family. Within this area, maize was important for women not only for market products, but also for their daily food. 


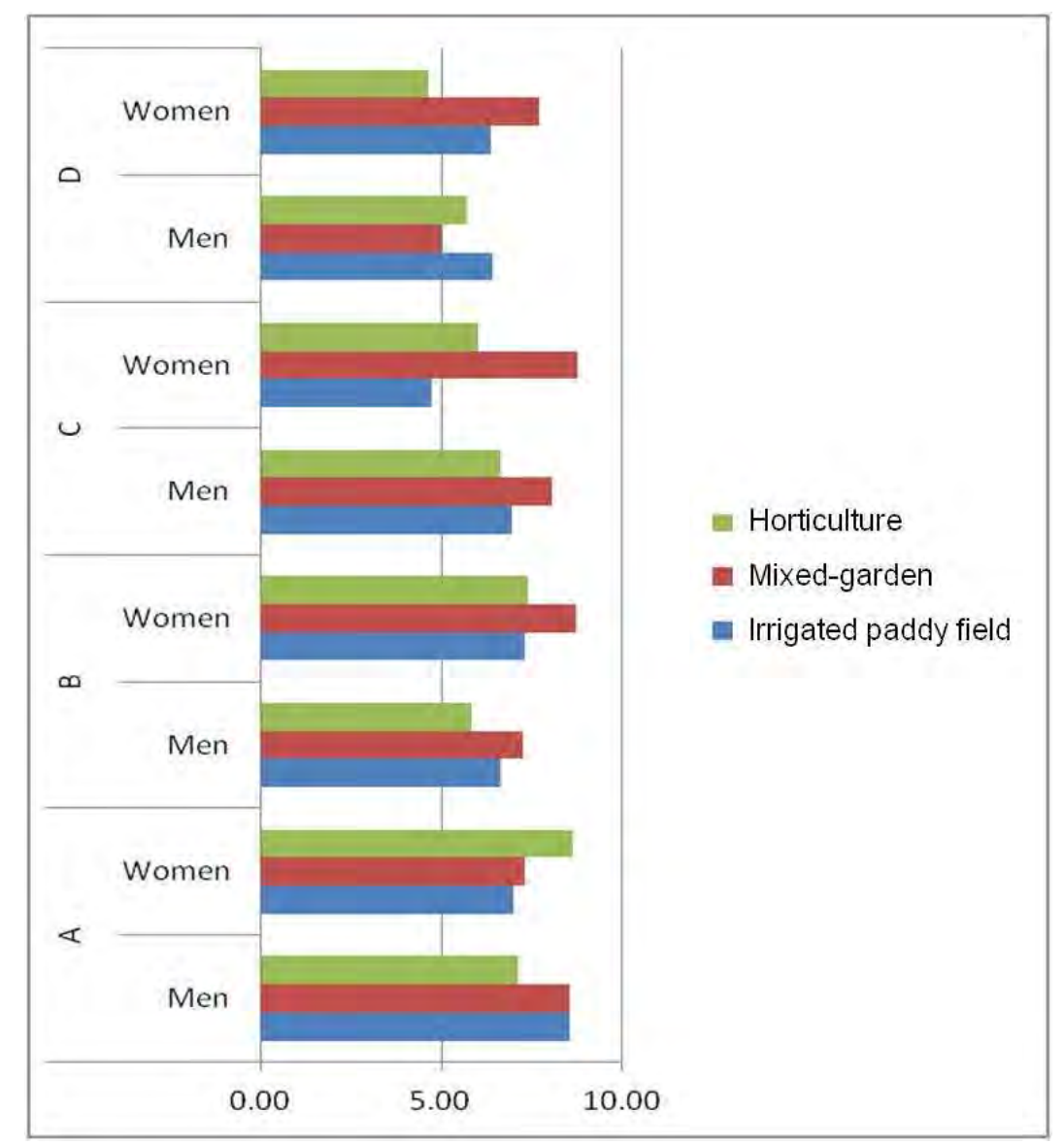

Figure 9. Importance of land-based livelihood sources for women from male and female perspectives (Horticulture refers to maize). Data source: FGD.

Interestingly, the other groups (men and women in Group B, men and women in Group C and women in Group D) indicated the same opinion of mixed-garden being the most important land-based livelihood source for their community as well as specifically for women. The discussion with the men's group in Group D (timber-based) demonstrated a slightly different opinion to the women's group, as they considered mixed-garden to not be very important for women. This shows that women and men have different perceptions about the importance of land uses for women. In Group A (degraded land), women placed high importance upon not only their involvement but also on the role of a livelihood source for the community. In Group D (timber-based), the different perceptions between men and women could be due to the men thinking that the importance of livelihood sources was purely related to women's involvement. Men in Group D (timber-based) thought that women were more involved with working with paddy and horticulture (maize and other crops) systems. Group D (timber-based) demonstrated different livelihood source patterns. Timber production was rated as an important livelihood source. However, the production is not from the forest, as only 
limited forest areas can be accessed by the community. Timber production was not considered very important for women compared with irrigated paddy field, mixed-garden, and horticulture (maize and other crops), although it can provide significant contribution towards household incomes. Women argued that although this can provide a high return, because they have fewer roles within timber production, they don't consider it to be of high importance.

This report will now focus on gender roles in livelihood systems. The roles of men and women within each livelihood source were discussed with the local communities. The results indicated that in all villages, women's roles (29.14\%) within mixed-garden systems were of a higher proportion compared with men's roles $(26.78 \%)$. Women's roles in horticulture plot and irrigated paddy field systems were also higher than men. Gender roles in forest-timber, and firewood production were dominated by men, as well as in many off-farm work activities. Female involvement in farm labour was slightly higher $(10.6 \%)$ than male $(10 \%)$.

Figure 10 configures gender involvement in each village typology based on discussions with the women's and men's groups. For mixed-garden, Group A (degraded land) indicated that the both men and women have the same proportion of roles. While in Group B (agroforest system in Bantaeng) and $\mathrm{C}$, women were indicated as having more roles as their proportion of involvement in mixed-garden activities were higher than men. Interestingly, Group D (timber-based) demonstrated a markedly different situation, with men's involvement in mixed-garden a higher proportion than women. Most work in the villages within Group D (timber-based) was related to timber-based products, and mainly dominated by men. In Group A (degraded land), a higher proportion of women were found in horticulture (maize and other crops) cultivation, irrigated paddy field and farm labour. Farm labour mostly related to work on irrigated paddy fields, farm labour, and harvesting cacao, clove or coffee that were more relevant to women's work. These illustrations are the same for Group B (agroforest system in Bantaeng).

From the figures, we can see that there are no significant differences between women and men's perceptions. Interestingly, different opinions between men and women were clearly seen in Group A (degraded land) where $100 \%$ of men thought that only men are involved in forest production, either for timber or non-timber forest products. The women's group considered that women have a role to be involved in forest production. However, the discussion process did not reflecting much on what happens with this difference, and so we may need to re-check this information or investigate further to ascertain the reasons behind this. 

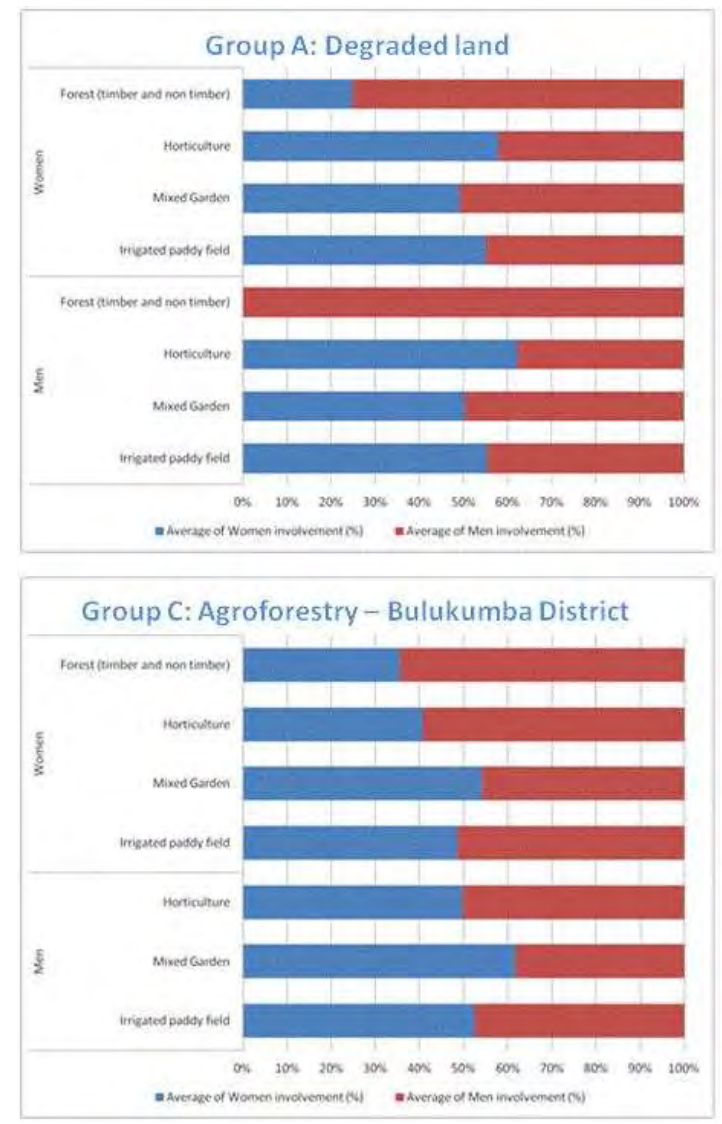

Figure 10. Gender involvement in livelihood sources based on the perceptions of men and women.

Data source: FGD.

It was consistent in every group that work related to timber production, from the forest or in private land, was usually dominated by men. Non-forest timber products related to the types of products produced from the forest. Rattan and fuel-wood harvesting usually related to men's work, although women were also involved. Mushroom and wild fruit collection usually involved women at a higher proportion than fuel-wood and rattan collection.

\section{Gender roles in the household}

Generally gender roles in households were defined in terms of how roles were divided on a daily basis. Women have the responsibility of maintaining domestic aspects; taking care of children, fulfilling family nutrition and other family needs. Men have more responsibility in earning the main income, therefore they had more opportunity to access public activities. A significant difference between male and female roles in the household, including agriculture production, was the time spent carrying out activities. Women woke up early in the morning, prepared food for all of the family members and took care of the children before they went to school. After their morning work is done, 
they went to work in the fields, then returned home to prepare food in the middle of the day and then some would return to the fields to work again until the afternoon. After working in the fields, they prepared dinner and assisted children with school homework. During the harvesting periods, although they work near the house, they have time-consuming responsibilities in the post-harvesting processes. Men worked in the field in the morning and afternoon, however during the midday break they could rest. In the afternoon, they were able to engage in other activities, including marketing and nonproductive leisure activities.

\section{Gender roles in farming activities}

This section discusses gender roles in specific farming activities in the whole study sites. Figure 11 describes gender roles in each farming system based on male and female perceptions captured in separate discussions. It seems that the high proportion of women's roles in farming systems are mainly in harvesting, post-harvesting, marketing and planting. Both male and female perceptions demonstrated the same pattern. Land preparation is clearly seen as men's domain, involvement of women in this activity was lower than men's. In each village group, the pattern is almost the same as illustrated above. There are some differences that female roles in Group D (timber-based) in nursery were perform a bit higher than men's role, while in other villages, men's role were seen higher. 


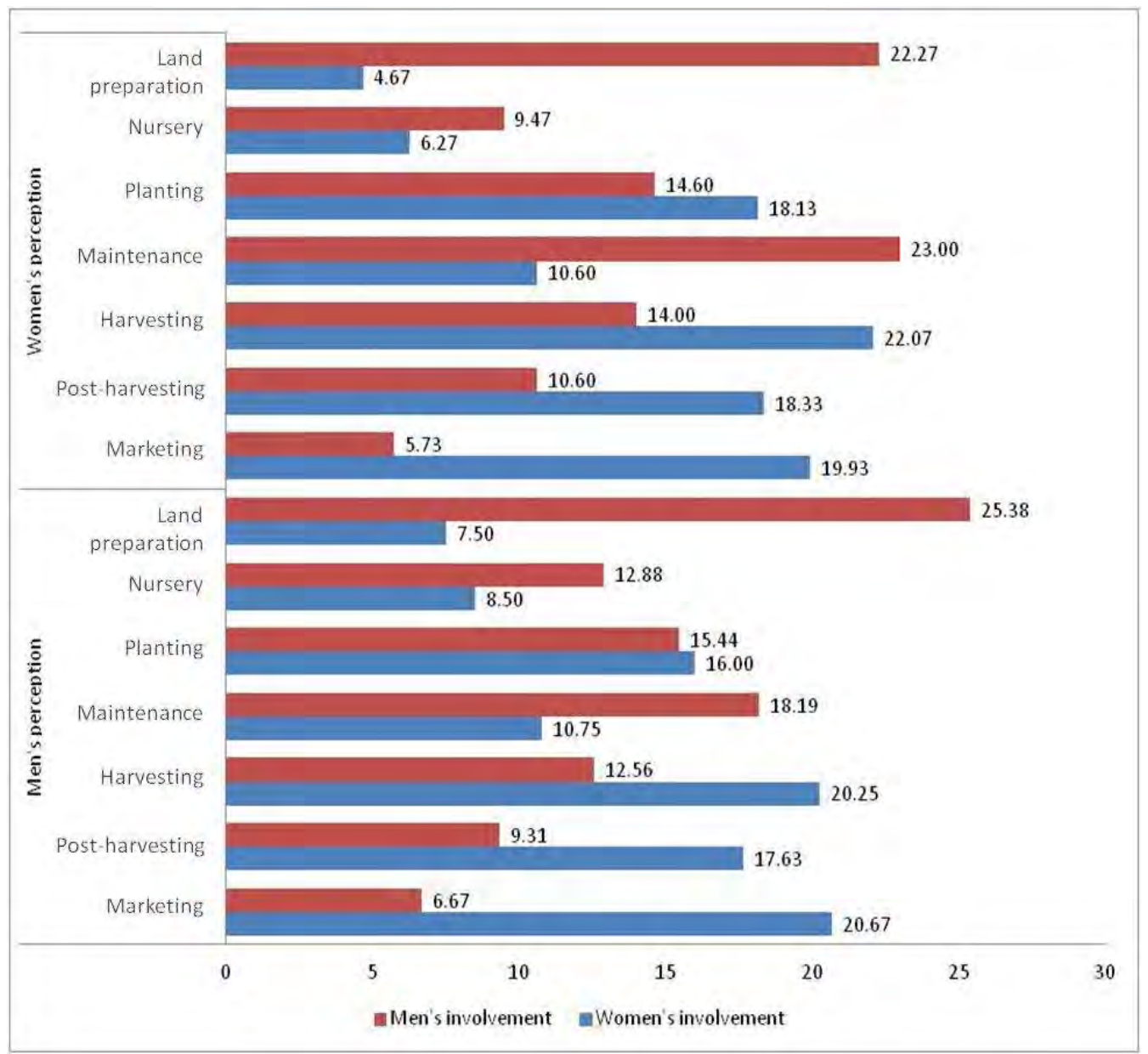

Figure 11. Gender roles in farming system activities in the whole study areas in South Sulawesi.

Data source: FGD.

Household interviews show that women's involvement in farming system activities was perceived as quite prominent (Table7). In most of the surveyed villages, this involvement was more than $60 \%$. In all areas the high proportion of women in farming system activities was mainly in post-harvesting and marketing. Other activities (in land preparation, planting and crop care) were dominated by men, with the involvement of women in these activities lower than men. 
Table 7. The role of women in farming system activities in South Sulawesi

\begin{tabular}{|c|c|c|c|c|c|c|c|c|c|c|}
\hline \multirow{3}{*}{ Activity } & \multirow{3}{*}{ Villages } & \multirow{3}{*}{$\mathbf{n}$} & \multicolumn{8}{|c|}{ The role of women in farming system activities } \\
\hline & & & \multicolumn{2}{|c|}{$\begin{array}{c}\text { Woman > } \\
\text { man }\end{array}$} & \multicolumn{2}{|c|}{$\begin{array}{c}\text { Woman }= \\
\text { man }\end{array}$} & \multicolumn{2}{|c|}{ Woman $<$ man } & \multicolumn{2}{|c|}{$\begin{array}{c}\text { No role for } \\
\text { women }\end{array}$} \\
\hline & & & $\mathrm{n}$ & $\%$ & $\mathrm{n}$ & $\%$ & $\mathrm{n}$ & $\%$ & $\mathrm{n}$ & $\%$ \\
\hline \multirow{4}{*}{$\begin{array}{l}\text { Land } \\
\text { preparation }\end{array}$} & Kayu Loe & 29 & 5 & 17 & 1 & 3 & 13 & 45 & 10 & 34 \\
\hline & Campaga & 29 & 2 & 7 & 3 & 10 & 16 & 55 & 8 & 28 \\
\hline & Balang Pesoang & 27 & 1 & 4 & 1 & 4 & 15 & 56 & 10 & 37 \\
\hline & Tugondeng & 30 & 2 & 7 & 3 & 10 & 15 & 50 & 10 & 33 \\
\hline \multirow[t]{4}{*}{ Planting } & Kayu Loe & 29 & 10 & 34 & 9 & 31 & 9 & 31 & 1 & 3 \\
\hline & Campaga & 29 & 5 & 17 & 5 & 17 & 15 & 52 & 4 & 14 \\
\hline & Balang Pesoang & 27 & 1 & 4 & 0 & 0 & 16 & 59 & 10 & 37 \\
\hline & Tugondeng & 30 & 3 & 10 & 5 & 17 & 14 & 47 & 8 & 27 \\
\hline \multirow[t]{4}{*}{ Cultivation } & Kayu Loe & 29 & 4 & 14 & 2 & 7 & 22 & 76 & 1 & 3 \\
\hline & Campaga & 29 & 2 & 7 & 3 & 10 & 24 & 83 & 0 & 0 \\
\hline & Balang Pesoang & 27 & 1 & 4 & 2 & 7 & 15 & 56 & 9 & 33 \\
\hline & Tugondeng & 30 & 1 & 3 & 5 & 17 & 21 & 70 & 3 & 10 \\
\hline \multirow[t]{4}{*}{ Harvesting } & Kayu Loe & 29 & 6 & 21 & 10 & 34 & 13 & 45 & 0 & 0 \\
\hline & Campaga & 29 & 3 & 10 & 10 & 34 & 16 & 55 & 0 & 0 \\
\hline & Balang Pesoang & 27 & 1 & 4 & 8 & 30 & 14 & 52 & 4 & 15 \\
\hline & Tugondeng & 30 & 6 & 20 & 13 & 43 & 10 & 33 & 1 & 3 \\
\hline \multirow{4}{*}{$\begin{array}{l}\text { Post- } \\
\text { harvesting }\end{array}$} & Kayu Loe & 29 & 12 & 41 & 7 & 24 & 10 & 34 & 0 & 0 \\
\hline & Campaga & 29 & 18 & 62 & 8 & 28 & 3 & 10 & 0 & 0 \\
\hline & Balang Pesoang & 27 & 18 & 67 & 5 & 19 & 4 & 15 & 0 & 0 \\
\hline & Tugondeng & 30 & 20 & 67 & 6 & 20 & 4 & 13 & 0 & 0 \\
\hline \multirow[t]{4}{*}{ Marketing } & Kayu Loe & 29 & 15 & 52 & 4 & 14 & 6 & 21 & 4 & 14 \\
\hline & Campaga & 29 & 21 & 72 & 4 & 14 & 4 & 14 & 0 & 0 \\
\hline & Balang Pesoang & 27 & 23 & 85 & 3 & 11 & 1 & 4 & 0 & 0 \\
\hline & Tugondeng & 30 & 25 & 83 & 2 & 7 & 2 & 7 & 1 & 3 \\
\hline
\end{tabular}

Data source: Household surveys.

Detailed discussion of gender roles will focus on three main farming activities from the whole study sites: mixed-garden based on cacao, coffee and candlenut cultivation, horticulture (maize) and irrigated paddy field systems. Similar to the configuration of gender roles in the all farming systems, within traditional agroforest or mixed-garden systems, men and women were both involved in each activity. The agroforestry system defined here refers to mixed-gardens based on an economic commodity such as cacao, coffee or clove. The proportion of women's involvement was high particularly in harvesting, post-harvesting and marketing (Figure 12). Land preparation is closely related to men's domain of work, and this activity was dominated by men. While men prepare the 
land (clearing, slashing and hoeing), women were usually involved in preparing and bringing food for workers ('maddokol'), and sometimes also helping in hoeing or slashing light trees.

In nursery work, women's responsibility was to fill the polybags with soil and seed. A few women also had responsibility for seed selection, but men had more roles in selecting high quality seed. While men hoe the soil to prepare the planting holes, women usually had responsibility for planting, placing the polybag in the hole pouring the water, and planting new vegetation.

In coffee and cacao cultivation, the discussion results found that women spent more time in crop husbandry than men. Planting, shaping and pruning work was largely undertaken by men; weeding, harvesting, post-harvest processing and packaging by women; and digging, mulching, managing pests and diseases being shared tasks. Men usually have better access to extension services and thus the ability to gain higher levels of skills (Martini et al 2013). Women tended to spend more time in the field and near to the house for coffee processing. In post-harvesting activities, men were usually found to undertake the carrying and weighting, with women the sorting, peeling, soaking, drying, and selling.

In maize and paddy production, the pattern is the same (Figure 13). Women were usually involved in planting, harvesting, post-harvesting and marketing. Within maize harvesting, women were responsible for picking the maize from the stem ('massepe'), while men toted the collected maize ('mateke') from the land to the house for further processing. Women had more responsibility for peeling the maize from the cob, drying it under the sun, toting, or grinding kernels for storing or marketing (men help to grind the maize when necessary).

In vegetable production, women were responsible for most of the activities including land preparation, seed preservation, planting, weeding, composting, harvesting, post-harvest processing and selling the surplus to farm-gate traders. Men were usually involved in interacting with input and output markets: the purchase of input supplies (seeds, fertilizer and pesticides), and selling the surplus in the markets. Both men and women applied the pesticides and fertilizers. If the vegetable production was for commercial purpose, men usually had more involvement. 


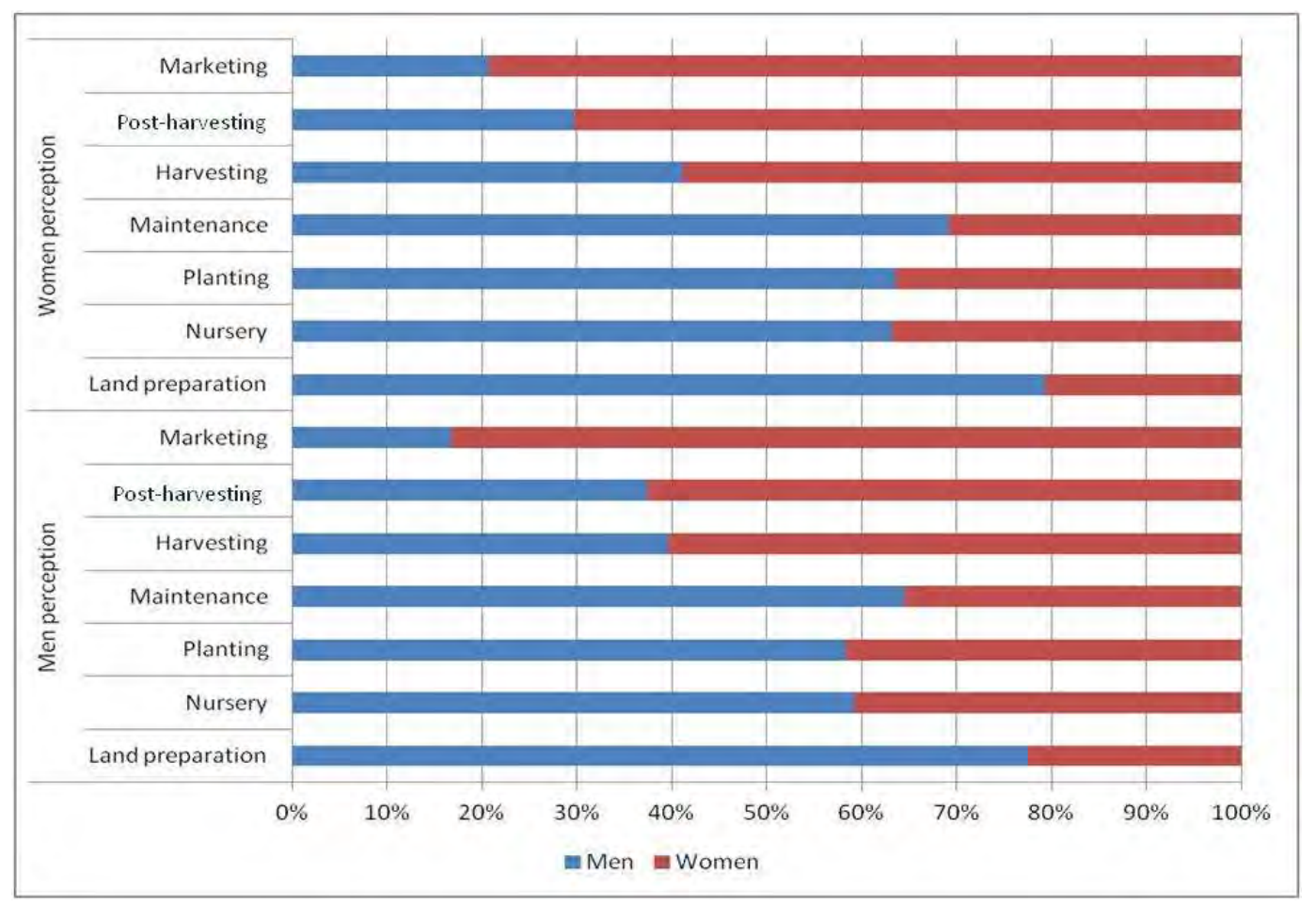

Figure 12. Gender roles in traditional agroforest. Data source: FGD
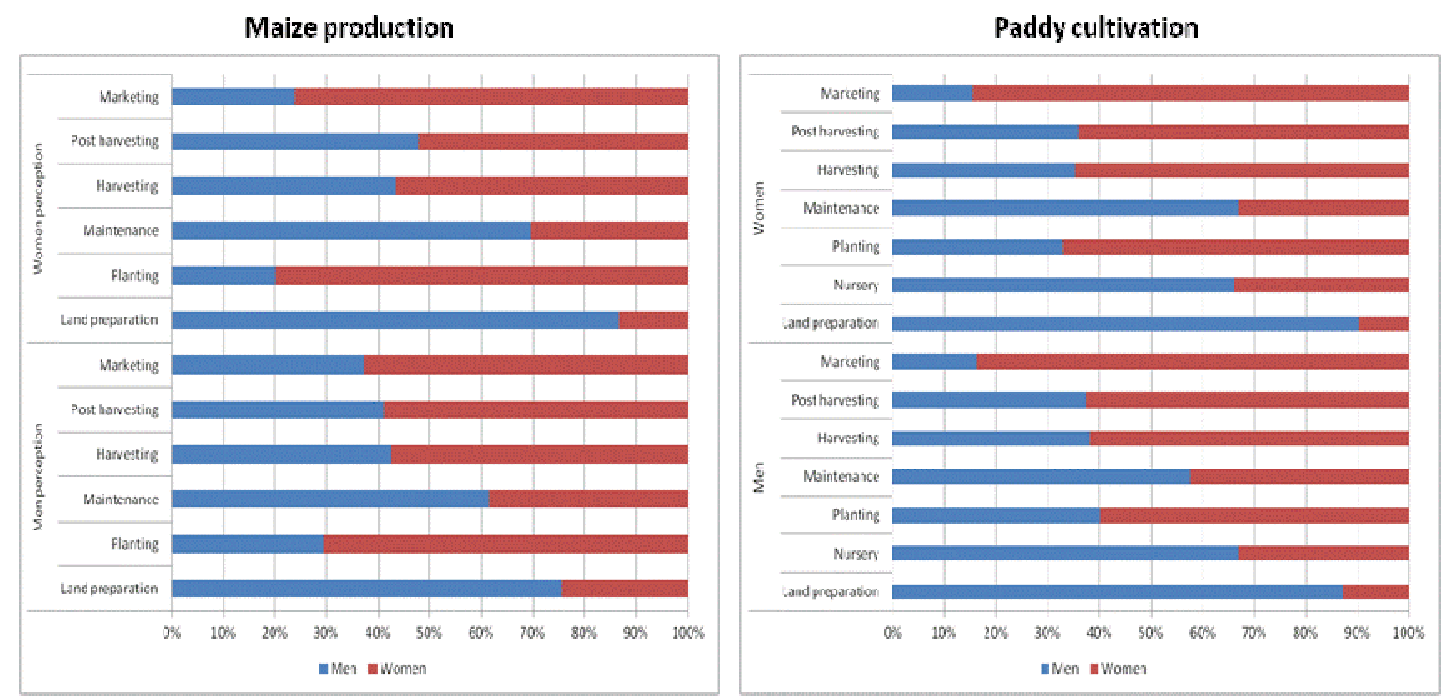

Figure 13. Gender division of tasks in maize production and paddy cultivation in irrigated paddy fields. Data source: FGD.

\section{Land and gender}

Discussions of gender and land closely relate to issues of equality of men and women in terms of land rights and decision-making. This section will discuss how gender roles influence, or are influenced by, the land and existing property rights systems. 


\section{Land ownership}

The majority of people in the surveyed villages owned and cultivated the land themselves. They usually owned land of 1-2 ha per household. Khususiyah et al (2013) in their research in South Sulawesi found communities obtain the land mainly from the inheritance process (51\%) and purchasing it (37.5\%). Forest clearing only occurred in two typologies, Kayu Loe and Balang Pesoang, but only in low percentages.

Table 8. Source of land in South Sulawesi

\begin{tabular}{|c|c|c|c|c|c|c|c|c|c|c|c|c|c|c|}
\hline \multirow{3}{*}{$\begin{array}{c}\text { Village } \\
\text { typologies }\end{array}$} & \multirow{3}{*}{ Villages } & \multirow{3}{*}{$\mathrm{n}$} & \multicolumn{12}{|c|}{ Source of land } \\
\hline & & & \multicolumn{2}{|c|}{$\begin{array}{l}\text { Husband's } \\
\text { parents }\end{array}$} & \multicolumn{2}{|c|}{$\begin{array}{l}\text { Wife's } \\
\text { parents }\end{array}$} & \multicolumn{2}{|c|}{ Relative } & \multicolumn{2}{|c|}{$\begin{array}{l}\text { Other } \\
\text { people }\end{array}$} & \multicolumn{2}{|c|}{$\begin{array}{c}\text { Primary } \\
\text { forest }\end{array}$} & \multicolumn{2}{|c|}{$\begin{array}{l}\text { Secondary } \\
\text { forest }\end{array}$} \\
\hline & & & $\mathrm{n}$ & $\%$ & $\mathrm{n}$ & $\%$ & $\mathrm{n}$ & $\%$ & $\mathrm{n}$ & $\%$ & $\mathrm{n}$ & $\%$ & $\mathrm{n}$ & $\%$ \\
\hline $\begin{array}{l}\text { Degraded } \\
\text { land }\end{array}$ & Kayu Loe & 70 & 29 & 41 & 14 & 20 & 3 & 4 & 22 & 31 & 0 & 0 & 2 & 3 \\
\hline \multirow{2}{*}{$\begin{array}{l}\text { Agroforestry } \\
\text { system }\end{array}$} & Campaga & 88 & 33 & 38 & 22 & 25 & 16 & 18 & 17 & 19 & 0 & 0 & 0 & 0 \\
\hline & $\begin{array}{l}\text { Balang } \\
\text { Pesoang }\end{array}$ & 67 & 16 & 24 & 14 & 21 & 8 & 12 & 24 & 36 & 2 & 3 & 3 & 4 \\
\hline $\begin{array}{l}\text { Timber- } \\
\text { based } \\
\text { system }\end{array}$ & Tugondeng & 85 & 21 & 25 & 18 & 21 & 14 & 16 & 32 & 38 & 0 & 0 & 0 & 0 \\
\hline \multicolumn{2}{|c|}{ Total respondents } & 310 & 99 & 32 & 68 & 21.75 & 10.25 & 12.5 & 23.75 & 31 & 0.5 & 0.75 & 1.25 & 1.75 \\
\hline
\end{tabular}

Data source: Khususiyah 2013

Land ownership in the study area usually belonged to men. When families buy the land, the land usually belongs to the husband or the man. Women may obtain land from the inheritance process, then they may claim that the land belong to them. Khususiyah (2013) show that in most areas, of the total respondents, there were $21.75 \%$ people who inherited land from the wife's parents, and $32 \%$ respondents who obtained the land from the husband's parents (Table 8). This could mean that if they obtained the land from the wife's parents, women could claim the land as theirs. Table 9 shows current land tenure status in degraded, agroforestry and timber-based areas. In degraded areas, most current land tenure status was owned by the husband (46\%), followed by the wife and husband (30\%), the wife (20\%) and other people (4\%). In agroforestry areas, most current land tenure status was owned by the husband (37-39\%), followed by the wife and husband (19-40\%), wife (16-27\%), and other people (6-15\%). Alternatively, most of the current land tenure status in timber-based areas was owned by the family (wife and husband), as much as $51 \%$. This was followed by the husband (24\%), wife $(20 \%)$ and other people $(6 \%)$. 
Table 9. Current land tenure status in South Sulawesi

\begin{tabular}{|c|c|c|c|c|c|c|c|c|c|c|}
\hline \multirow{3}{*}{$\begin{array}{c}\text { Village } \\
\text { typologies }\end{array}$} & \multirow{3}{*}{ Village } & \multirow{3}{*}{$\mathbf{n}$} & \multicolumn{8}{|c|}{ Current land tenure status } \\
\hline & & & \multicolumn{2}{|c|}{$\begin{array}{l}\text { Wife and } \\
\text { Husband }\end{array}$} & \multicolumn{2}{|c|}{ Husband } & \multicolumn{2}{|c|}{ Wife } & \multicolumn{2}{|c|}{$\begin{array}{l}\text { Other } \\
\text { people }\end{array}$} \\
\hline & & & $\mathrm{n}$ & $\%$ & $n$ & $\%$ & $\mathrm{n}$ & $\%$ & $\mathrm{n}$ & $\%$ \\
\hline $\begin{array}{l}\text { Degraded } \\
\text { land }\end{array}$ & Kayu Loe & 70 & 21 & 30 & 32 & 46 & 14 & 20 & 3 & 4 \\
\hline \multirow{2}{*}{$\begin{array}{l}\text { Agroforestry } \\
\text { system }\end{array}$} & Campaga & 88 & 17 & 19 & 34 & 39 & 24 & 27 & 13 & 15 \\
\hline & $\begin{array}{l}\text { Balang } \\
\text { Pesoang }\end{array}$ & 67 & 27 & 40 & 25 & 37 & 11 & 16 & 4 & 6 \\
\hline $\begin{array}{l}\text { Timber-based } \\
\text { system }\end{array}$ & Tugondeng & 85 & 43 & 51 & 20 & 24 & 17 & 20 & 5 & 6 \\
\hline
\end{tabular}

Source: Khususiyah 2013.

Formally, the name on the land certificate is usually the man's, especially when they purchased the land. There is the possibility for women to put their name in the certificate, but only when women obtain land from the inheritance process.

Table 10. Land holding status in surveyed villages in South Sulawesi

\begin{tabular}{lllll}
\hline & $\begin{array}{l}\text { Average } \\
\text { area in each } \\
\text { village }\end{array}$ & $\begin{array}{l}\text { Who owns the } \\
\text { land (mention } \\
\text { in land letter) }\end{array}$ & $\begin{array}{l}\text { Who has } \\
\text { rightfully } \\
\text { inherited the land }\end{array}$ & $\begin{array}{l}\text { Who has rights to } \\
\text { manage the land }\end{array}$ \\
\hline $\begin{array}{l}\text { Irrigated } \\
\text { paddy field }\end{array}$ & $0.2-1$ ha & Women & $\begin{array}{l}\text { Women and men } \\
\text { with the proportion } \\
\text { of women half of } \\
\text { the men's }\end{array}$ & $\begin{array}{l}\text { Men have larger } \\
\text { rights to cultivate the } \\
\text { land }\end{array}$ \\
\hline Maize farm & $0.2-2$ ha & Women & Same as above & Same as above \\
\hline $\begin{array}{l}\text { Mixed- } \\
\text { garden }\end{array}$ & $0.5-4$ ha & Women & Same as above & Same as above \\
\hline
\end{tabular}

Source: FGD.

\section{Land use perspectives}

This section explores local perceptions of land use systems and their functions, which is reflected in their perceptions of the importance of existing farming systems. Weight ranking or pebble distribution methods were employed as practical methods to assess the importance of land use systems. Land use classification in this study was defined based on local points of view. People were asked for the main land use systems in their village and surrounding areas. They then placed importance on each criteria for each land use system, using a '100 button'. Criteria were defined based on environment and livelihood. Environment refers to land use value (importance) related to environmental issues, such as 
biodiversity, soil protection, water reservoir, and climate. Livelihood indicates the importance of land use for source of income, subsistence fulfilment, and also other values related to ritual/cultural and medicinal plants.

Data compilation from the whole discussion showed that the local community placed more weight upon livelihood rather than environment functions (Figure 14). They highly scored most of the livelihood criteria, as they gained direct benefits from these in relation the impact on their daily life. Environmental values were perceived as indirect benefits, therefore they scored these as of low importance.

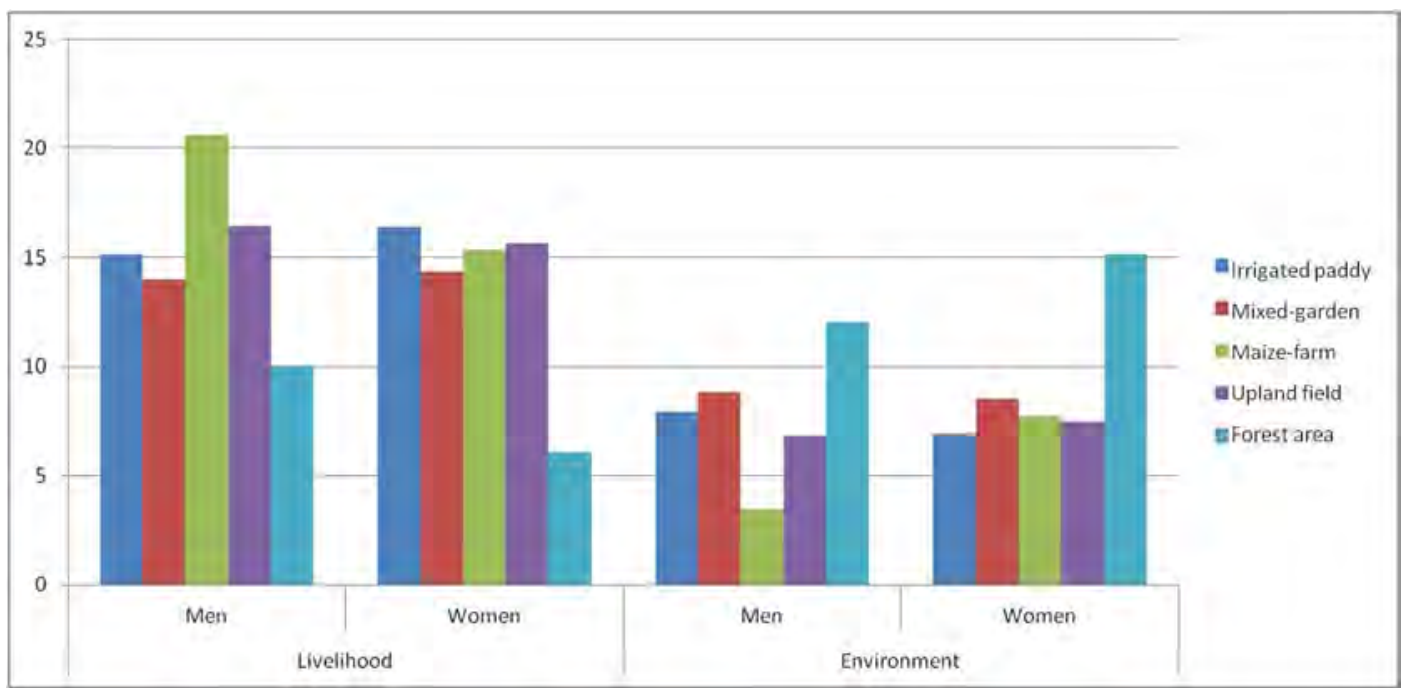

Figure 14. Livelihood and environment functions of each land use system based on gendered points of view.

Data source: FGD .

The forest was considered to have a high value of environmental importance. Both women's and men's group discussions shows the same tendency for the forest to be valued relatively high in term of the environment compared with other land use systems. This pattern was also similarly found in the data regarding village typologies, where forest was more valued in terms of the environment rather than as a livelihood source (Figure 15, Figure 22). The importance of the forest was mostly in relation to land and soil conservation (women's group weighted at 22.75 and men's group 13.6), followed by water conservation (men's group 17.2 and women's 16), then by climate (men's group 11 and women's 13.75), and biodiversity issues (men's group 9.8 and women's group 12.25). Issues regarding soil and water conservation were more popular for the local community, as some have already become aware of this through information from television and other sources. Biodiversity and 
climate regulation is more abstract for the local community, as farmers haven't yet had to pay a lot of attention to this.

Mixed-garden systems have become a very important livelihood source for the local community (Figure 16). The main function of mixed-gardens for both women and men was as an income source and to fulfil subsistence need. The value of mixed-gardens in terms of the environment was mainly regarding land and soil conservation, and for biodiversity. For women, the main function of agroforestry was for biodiversity, and for men, land conservation was the main function of agroforestry plots. People's knowledge of natural resources and land use was related to how often they saw benefits as related to their daily life. It may be because it is the male farmers who usually deal with issues of soil and land erosion or landslides that they tend to place value on soil and land conservation more highly than on other criteria. As women have the responsibility of fulfilling household nutrition, the issue of biodiversity was therefore more important to them. They may use a variety of vegetation species from the mixed-gardens for food, making simple tools, medicinal plants, and other aspects. 


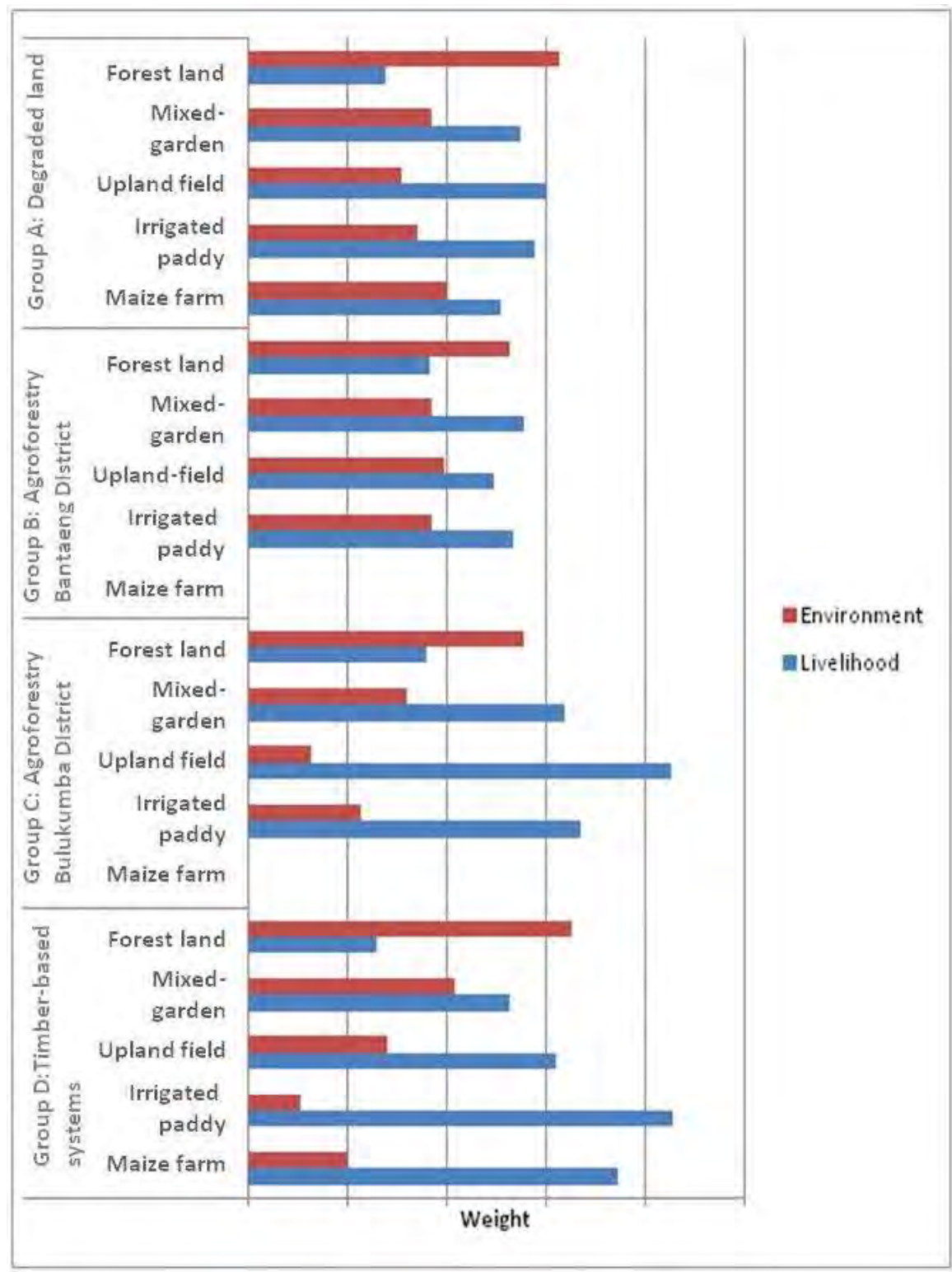

Figure 15. Livelihood and environment functions from each land use system based on village typologies.

Data source: FGD.

This is a good example of the way masculine and feminine traits influenced how people measured gender. The masculine trait of 'protector' usually related to men's tasks. The feminine principle of producing life (Shiva 1988), related to their understanding of the biodiversity functions that are usually maintained by women. This is a very interesting issue that could be discussed in more depth, in the future. 


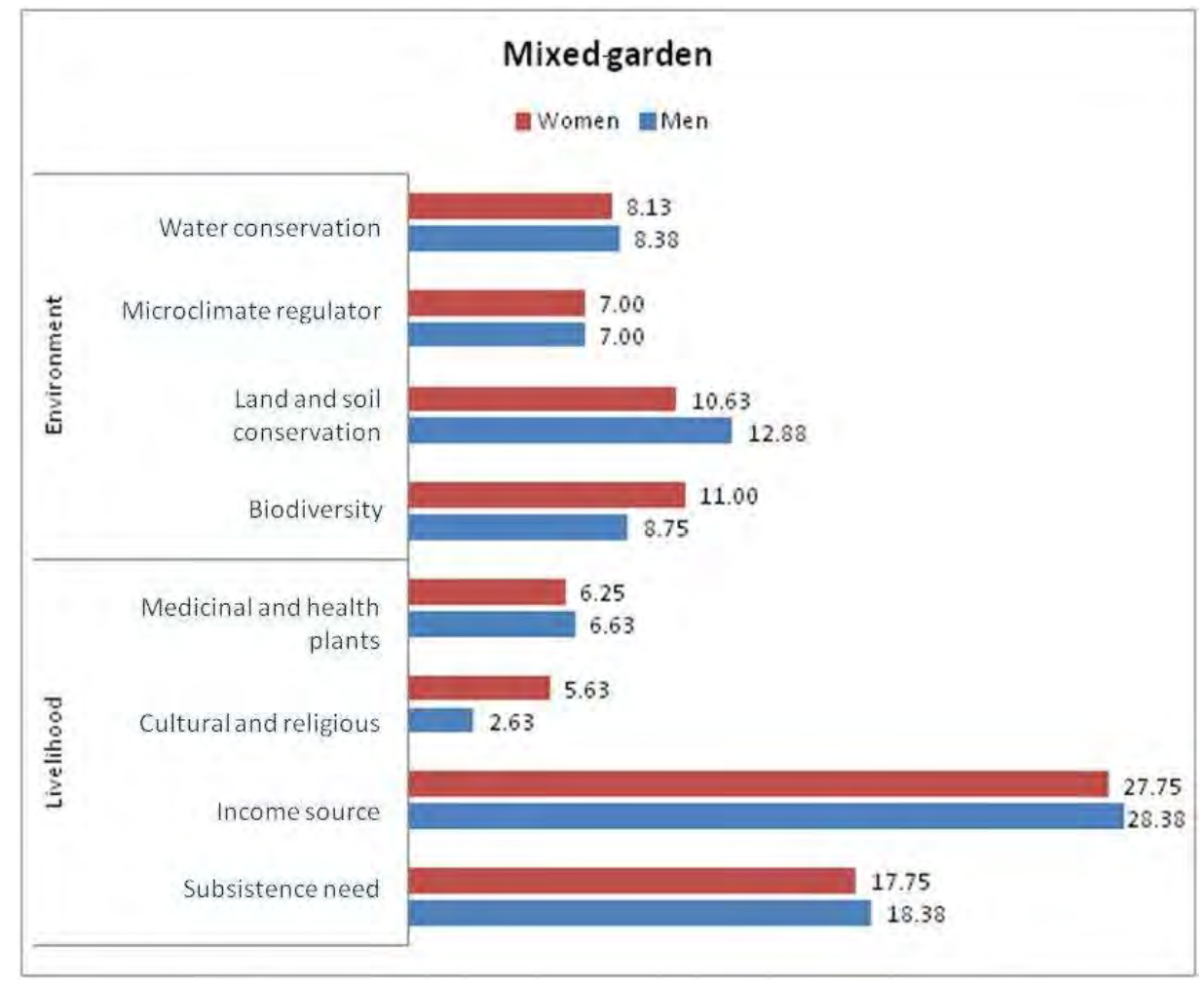

Figure 16. Gendered perceptions of the importance of mixed-garden systems. Data source: FGD. 


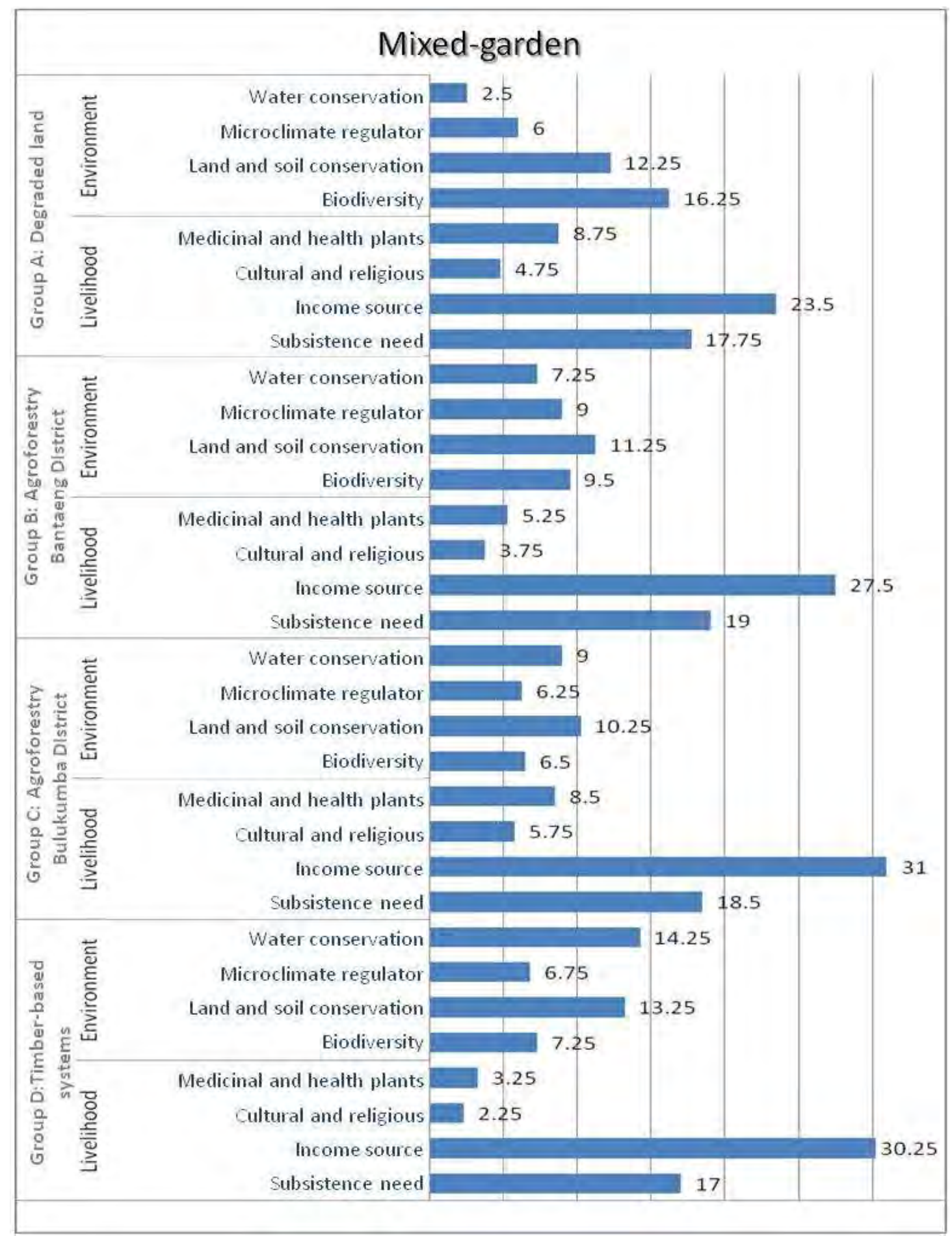

Figure 17 Perception of the importance of mixed-garden systems in each village typology. Data source: FGD.

The irrigated paddy field system was valued by women and men mainly for fulfilling subsistence need, and then as a source of income (Figure 18). The different perceptions by men and women of the value of this land use regarded medicinal plants, which none of the men saw as important for this system. Women usually used the wild plants near the paddy field for traditional curing. This was the 
reason why women perceived this aspect as important. This figure also shows us that men valued land and soil conservation, while women valued biodiversity. This was the same with the analysis on mixed group systems, where women were more concerned about the use of vegetation within the system, while men had more concern about the wider level (landscape) to protect soil erosion and landslides. Deeper analysis is needed to prove this premise, and this might be an interesting research topic for the future.

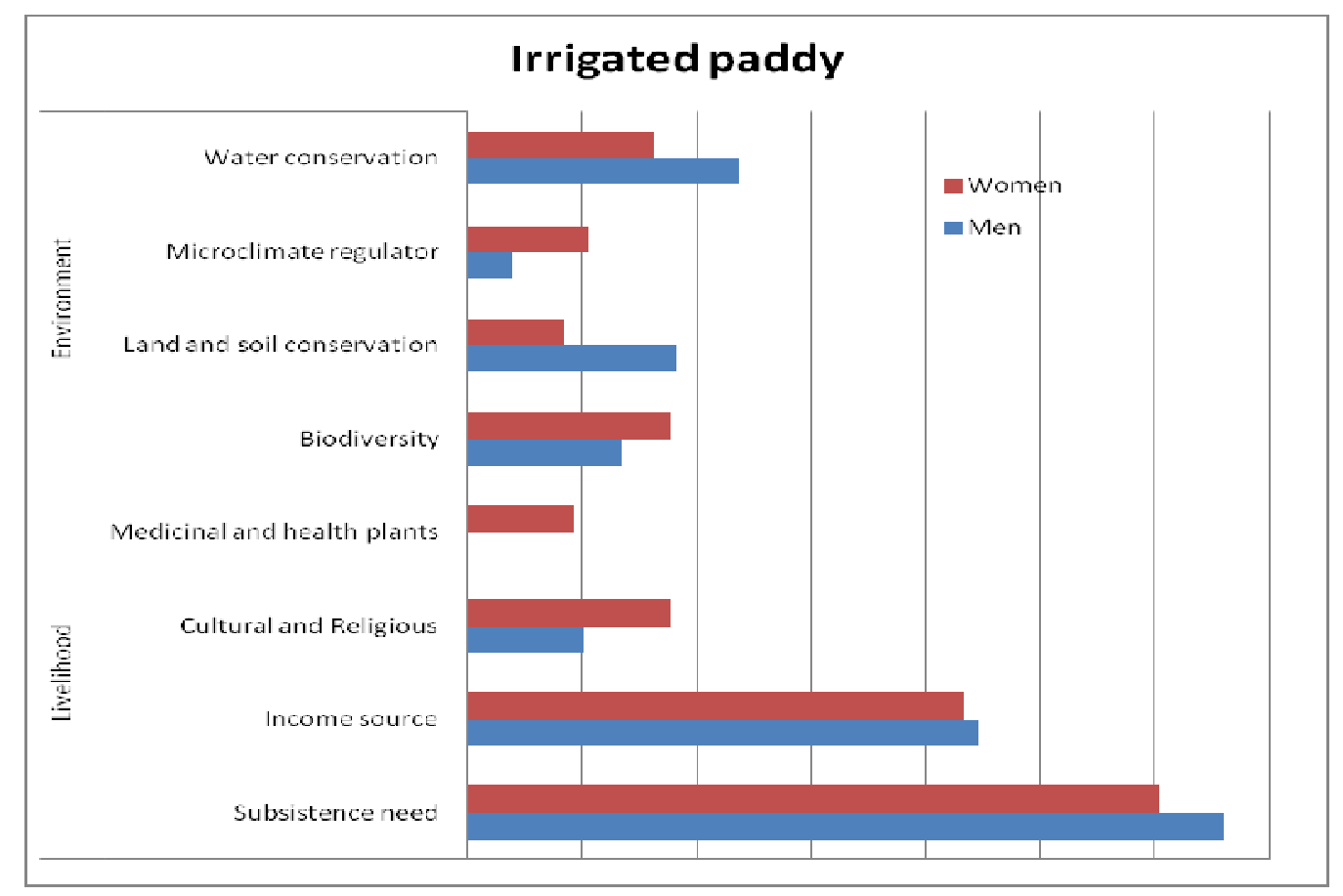

Figure 18. Gender perceptions of the importance of irrigated paddy field systems. Data source: FGD.

Maize farming (Figure 21) was considered an important source of income for local communities in Bonto Karaeng and Kayu Loe villages (Group 1), and for the villages of Tana Towa and Tugondeng (Group 4). People in these areas also used maize for subsistence. A significant rating of maize as providing income and subsistence was seen in Group 1 only. This is consistent with general observations, and other findings about the different livelihood sources within these two groups. The community in Group 1 were very dependent on maize farming as a source of income, while the people in Group 4 people had other alternative livelihood sources. In terms of the different perceptions by men and women regarding the value of land uses, the pattern was almost the same for irrigated paddy field systems. The value of the environment was low (Figure 20). Men's groups did not perceive that maize farms possess a microclimate function regulator, but women did perceive this, discussing the way in which the trees nearby the plots function to cool the climate. 


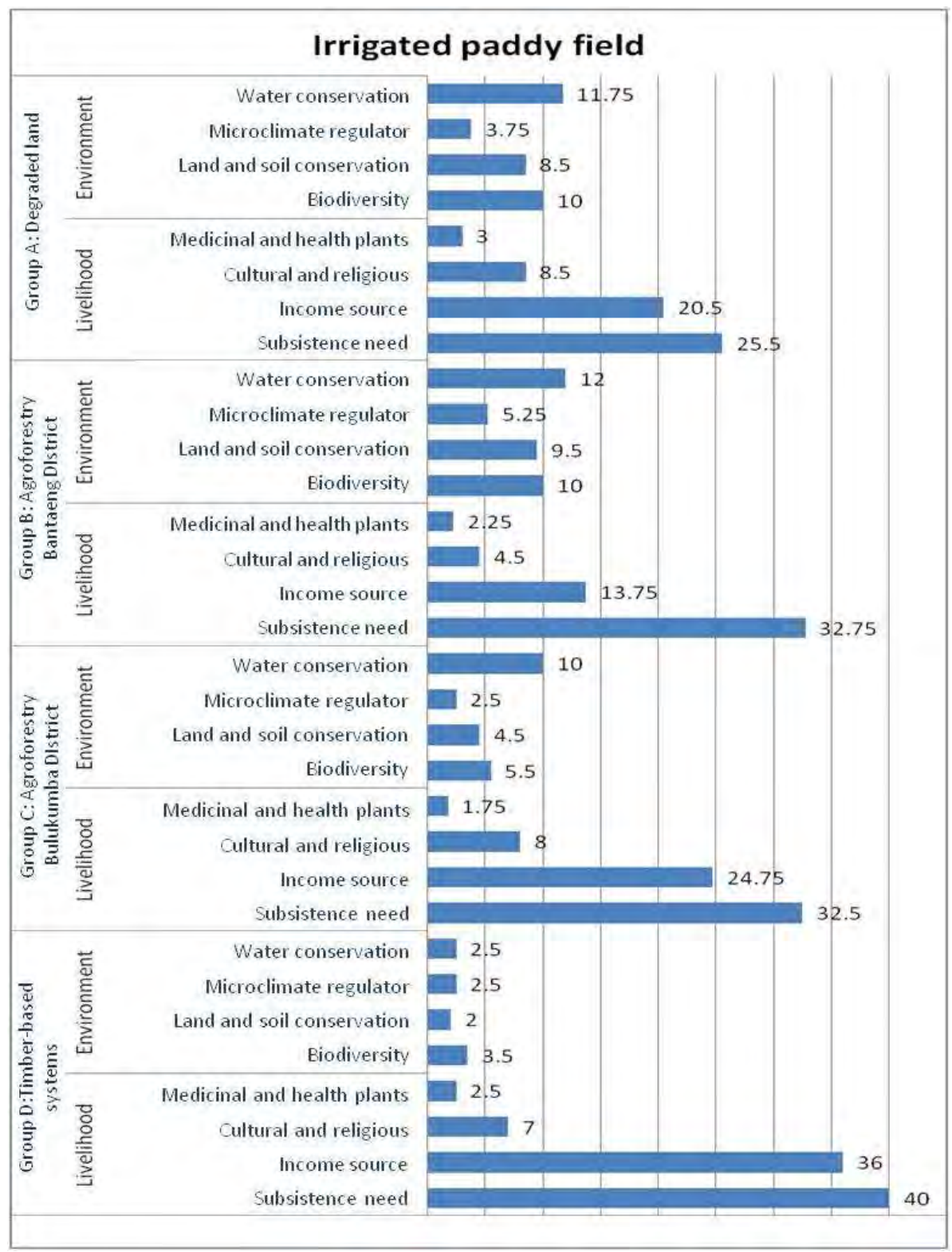

Figure 19. Perception of the importance of irrigated paddy fields in each village typology. Data source: FGD.

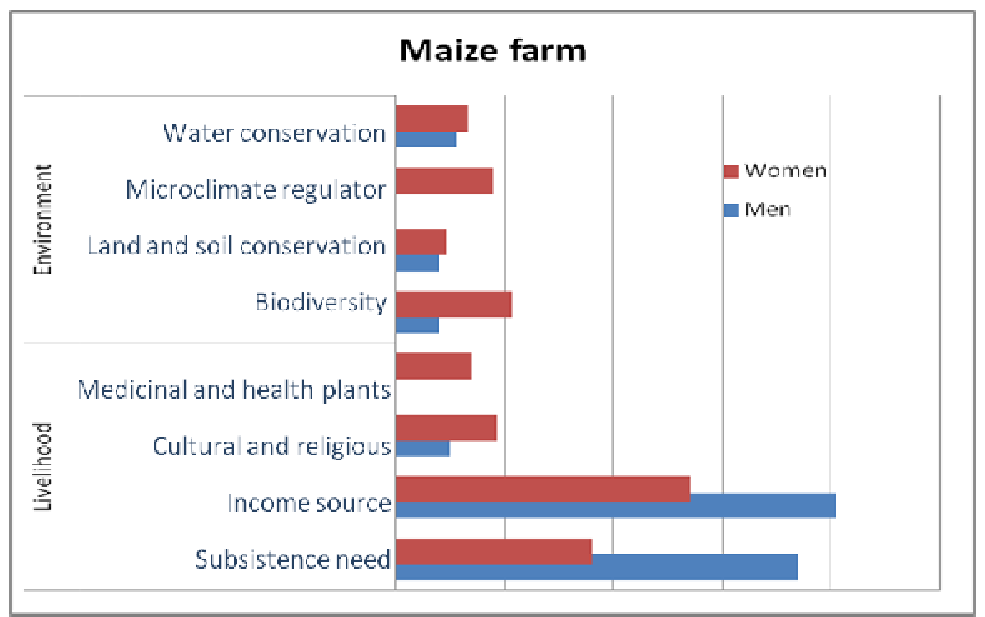

Figure 20 Gender perceptions of the importance of maize farming. Data source: FGD. 


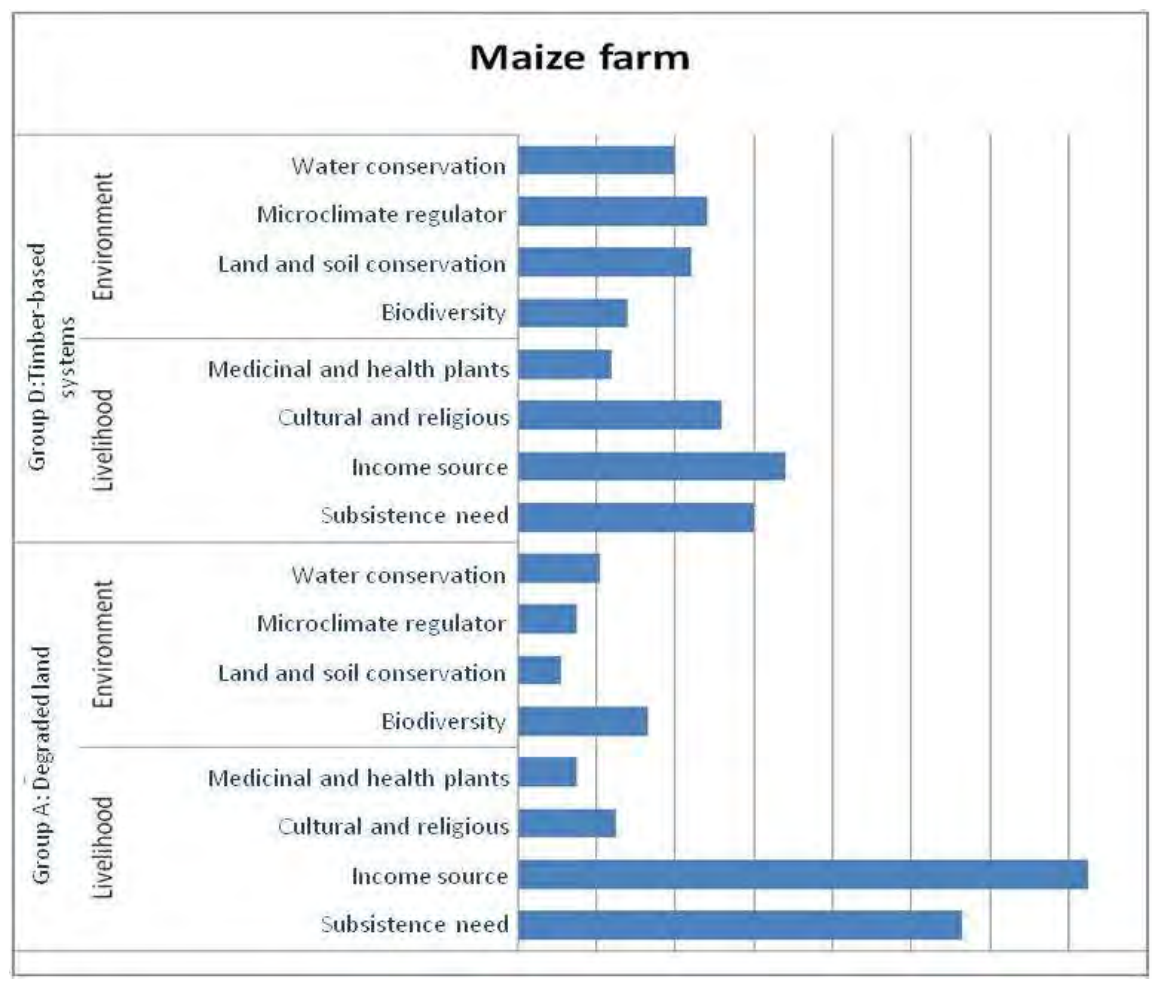

Figure 21. Perceptions of the importance of maize farming in each village typology. Data source: FGD.

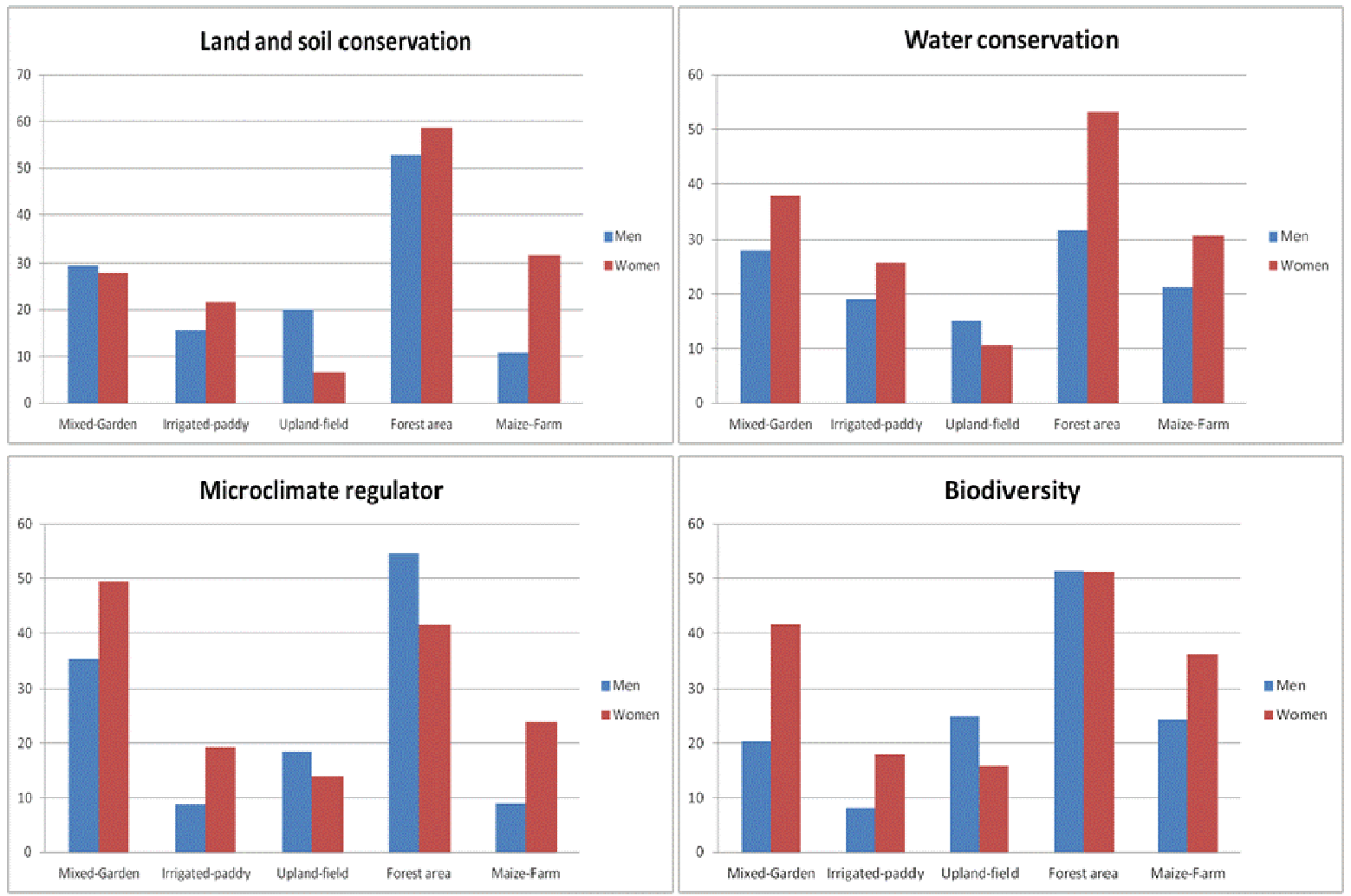

Figure 22. Perceptions of the environmental value of the land use. Data source: FGD. 


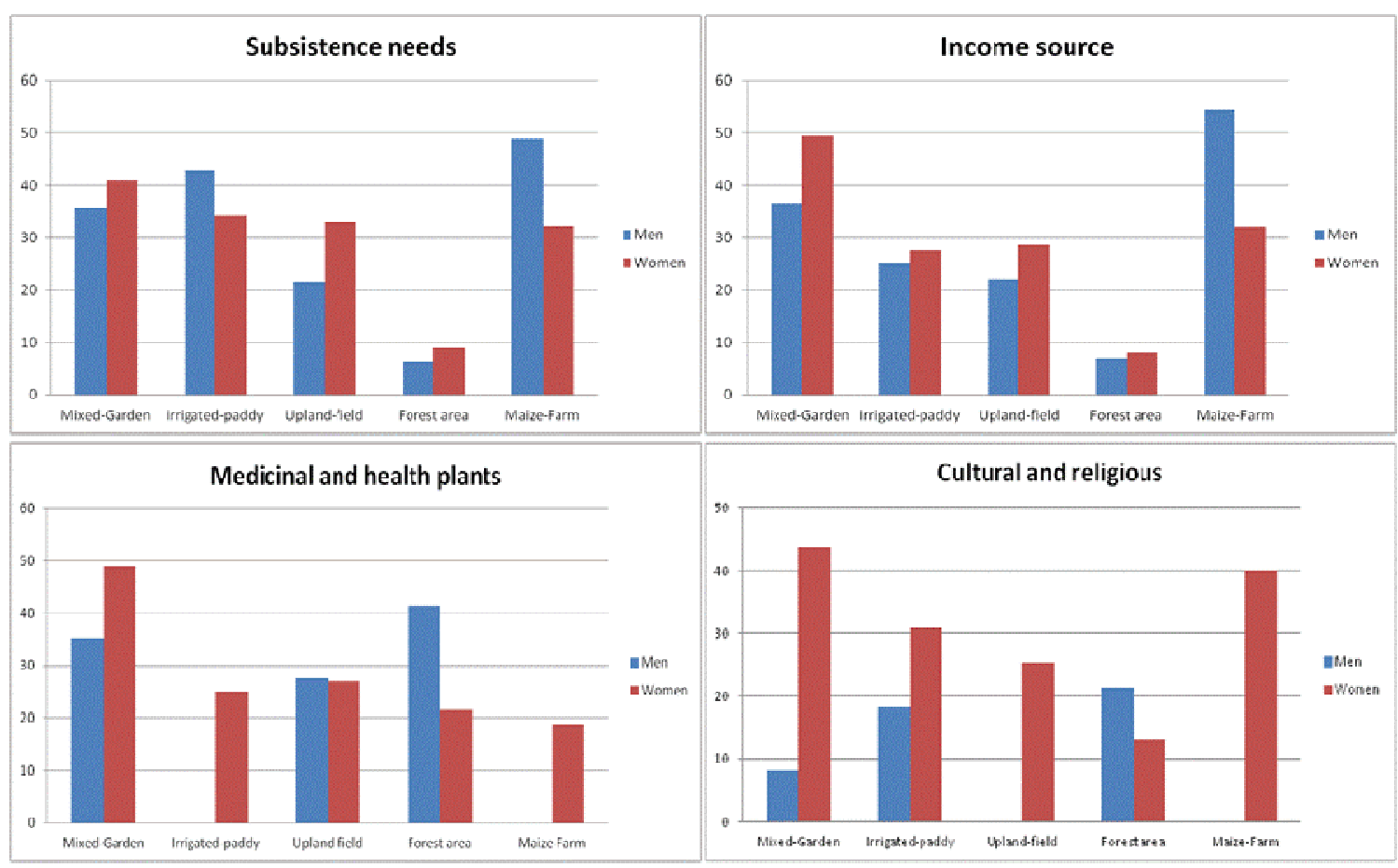

Figure 23. Perception of livelihood value or its importance for the land use. Data source: FGD.

\section{Gender and the market}

Economists describe the market as the place where buyers and sellers are brought into contact with each other and goods and services are exchanged. The term refers to the condition in which buyer and sellers make transactions (bought and sold) in any arena (Swedberg 2005, Portes 2010). Sociologists define the market as a social institution constructed from elements of culture. Markets are controlled and regulated by a particular social group or certain classes, which has links with other institutions, processes and social structures (Portes 2010). In this study, we will see how the market is not only the place for transactions, but related to social and cultural structures contributing to construct the market itself.

As discussed earlier, discussions with groups of women and men in the study area indicated that the involvement of women in the market was relatively high in comparison to other areas. Figure 24 shows women's involvement in marketing aspects of common commodities such as coffee, cacao, candlenut, vegetables, maize and cloves were higher than men's. Men's roles in marketing timber, firewood, and rubber latex were higher than women's. The commodities associated with the female domain were vegetables, as they are usually cultivated near the home (homegarden) on in plots easily accessed by women. Timber and wood were not associated with women, as women usually cannot estimate timber value and have limited information regarding price. In one discussion participants 
mentioned that timber transactions usually take place in areas located far from the house, near the forest or where timber located, thus this is men's domain.

While women sold cacao, this transaction took place in housing areas. Women gathered the cacao from the garden, peeled it, cleaned the seed, dried it under the sun for several days, and then sold it when the middleman/buyer comes to their house periodically (once every two weeks). This situation is unique in generating the involvement of women within marketing to be relatively high. It was not necessary for women to leave their house and domestic responsibilities, and they were also able to be more productive. Although women benefited from this system, it should be noted that the restriction of farmers to only one market channel alone can be detrimental to their opportunities. If farmers have the ability to access more than one market channel then their bargaining position is improved. Moreover, if more information is available regarding the market chain and related market information, then bargaining power for farmers is increased.

Women argued that they were able to successfully bargain the price of cacao with the seller, as they possess good bargaining skills. Both the men and women's groups consistently mentioned that the cacao price that women obtain is higher than that which men obtain. However, it should be noted that the ability of female farmers to negotiate is limited by their lack of information about the market, as they are only able to bargain within a price range of IDR 200 more than the farmer's level price for the commodity. They are unaware of the prices that the commodity reaches higher in the market chain.

Therefore, although women have high potential for being more involved in marketing agroforest production, their position in the market chain should be strengthened. This also should extend beyond women, to all farmer/producers. Farmer's access to market information should also be further expanded. 


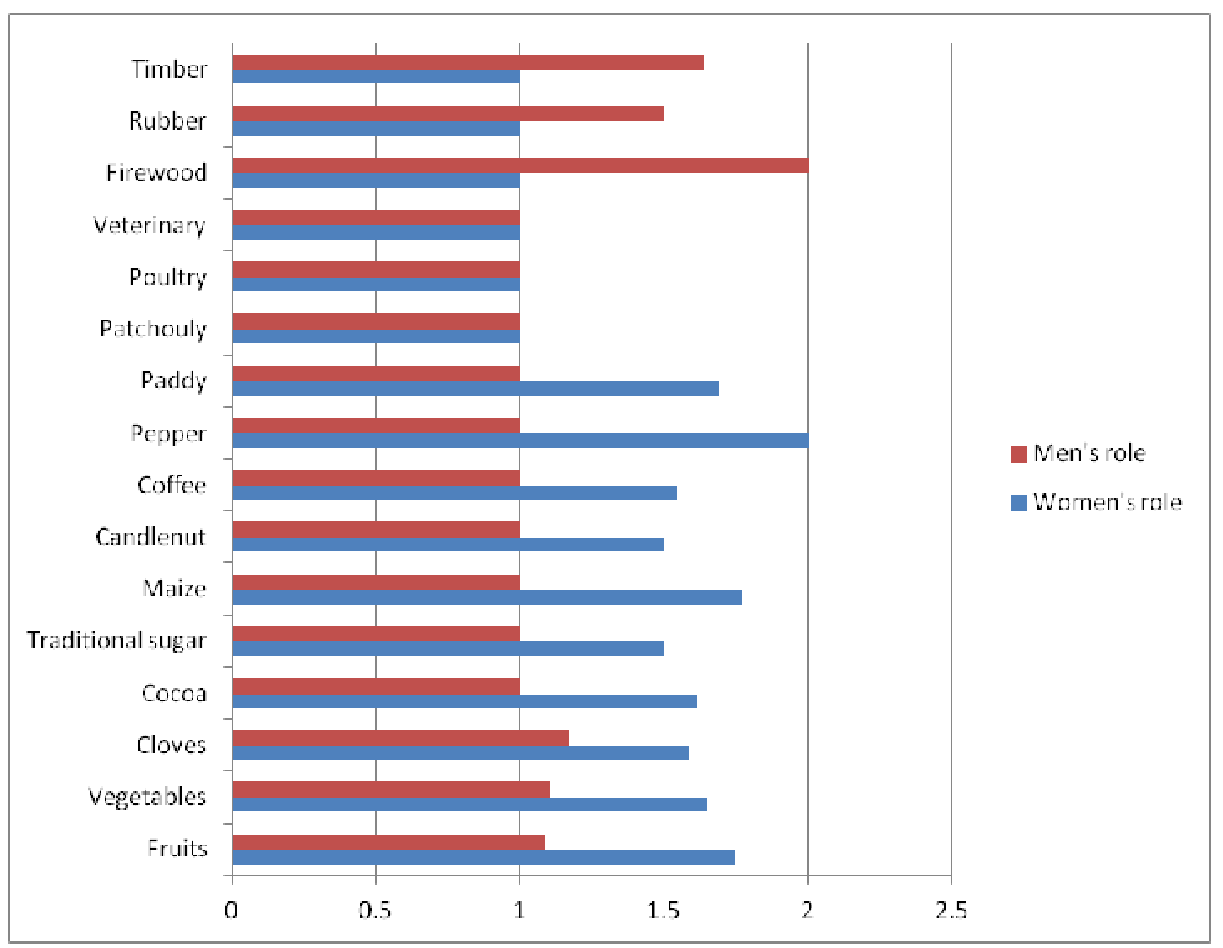

Figure 24. Gender roles within the marketing of each common commodity. Data source: FGD.

Gender issues within the market chain can be seen through the linkage of economic or market agents. Farm and plantation produce is sold to middlemen at village level, then resold to intermediaries/wholesalers at sub-district and district levels, then sold to traders, and finally sold again to exporter traders at the provincial level/manufacturers. This study encountered very few farmers who sell directly to large traders located out of the village, as the middleman or local trader comes to the site to deal with women. The connection between farmers to the strategic trader is thus hindered by local traders, resulting in farmers receiving a very low price (Perdana 2012). Although farmers can negotiate the prices, the range of prices were already fixed.

For women to gain understanding of the market chain from the producer to the end consumer would be important in determining the quality of commodities produced, and would help to raise the price of these commodities. Economic agents or market agents were still dominated by male traders. The analysis by Kiptot (2011) showed that women as agents of the market are usually involved in smallscale trade, linking smallholder producers to the large merchants. In her study, Kiptot also mentioned that men are more dominant in large-scale trade. Sulawesi demonstrates a similar pattern. Middlemen can be found at the local level dealing directly with the farm household—usually the traders are also retail merchants who sell household goods directly to consumers at local level. 


\section{Gender and poverty}

Discussing poverty alleviation must relate to how poverty is defined. Most of the programs to eradicate or alleviate poverty use criteria developed from general and standardized indicators, which may not match with the local condition. Deprivation and poverty were defined based on poor people's wants and needs in this study. Moreover, poverty was not perceived only in relation to the income and expenditure dimension but also to other dimensions that might be more relevant within the local context. Poverty should be seen as a process of deprivation and the relations between the poor and non-poor.

Defining poverty status based on local perception is an important stage in defining local criteria and indicators to identify and design interventions. It can capture the multidimensional aspect of poverty and the processes within it. Poverty definitions were used to assess the current condition of communities, to ascertain levels of well-being. In discussions, farmers were asked to define what kind of criteria they use to differentiate the community's poverty or well-being conditions. The criteria as described below was summarized from all discussions held with the community:

- Do not have proper land for farming

- Land size less than 0.5 ha per household

- Do not have land

- Do not have permanent job

- Do not have proper house

- Quality of house from bamboo, round timber, etc

- Do not have house

- Income

People without land were categorized as very poor, and people with land less than 0.5 ha were categorized as poor. A permanent job or certain /regular income was the second rank of poverty definition. People without a certain job that could provide regular income were categorized as poor. The third category was assets or house condition. People were defined as very poor if they didn't have a house or land for a house, and people with a low quality of house were defined as poor. The amount of income that people received was the fourth ranking. Income below IDR 1 million per month was categorized as poor. For the minimum income, people may require around IDR 1.5 million per month to reach the category of lowest well-being.

Figure 25 shows the different perceptions of defining poverty, by men and women. Men defined land availability for each household, regular income from a certain job, household assets, and the amount 
of income as the indicators from highest to lowest rank, respectively. For women, well-being was defined in relation to household property and assets, then land ownership, followed by job availability and the amount of income. These differences show that for women and men, physical criteria is more important than income itself. Land was considered important as it can provide income as well as fulfil subsistence need for men as the income earners in the family. House property was important for women as it indicates the family's standard of living.

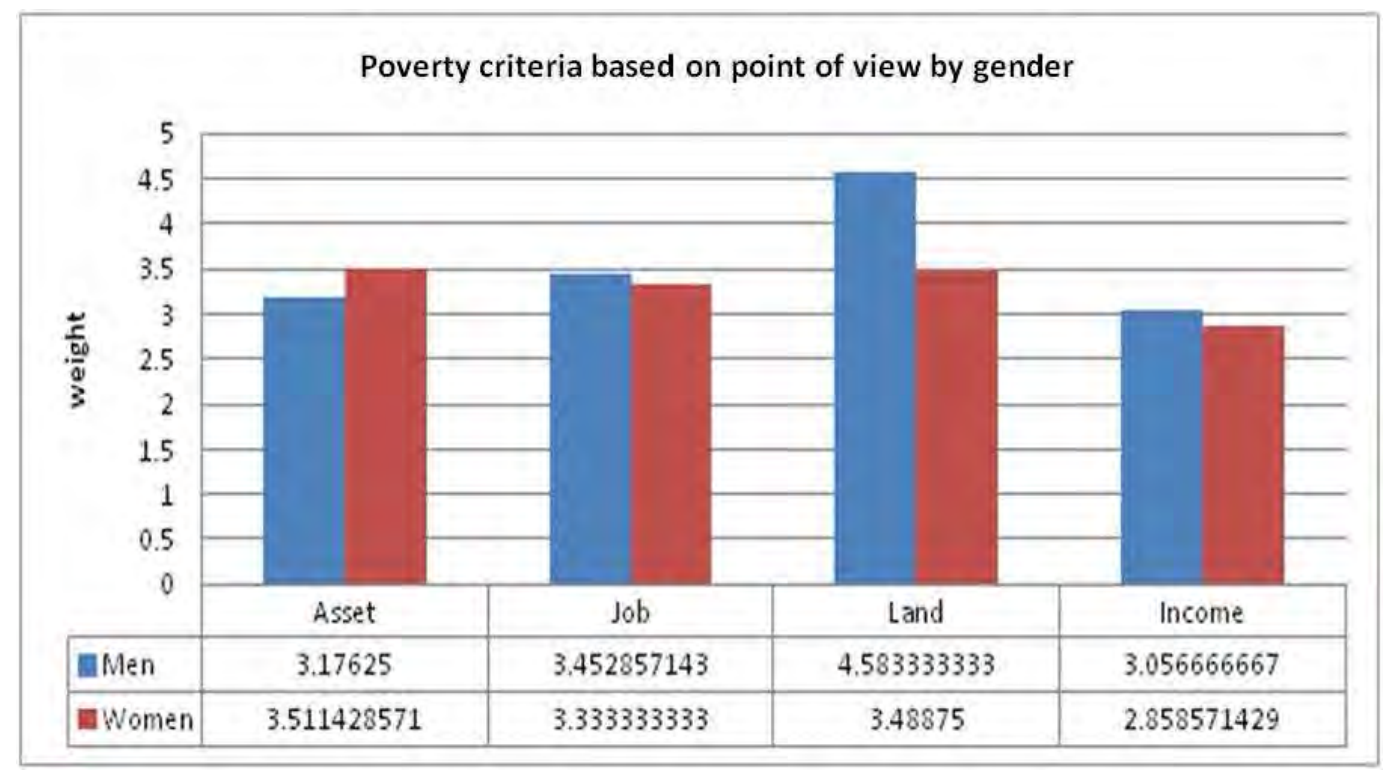

Figure 25. Criteria used to define well-being and/or poverty based on different gender perspectives

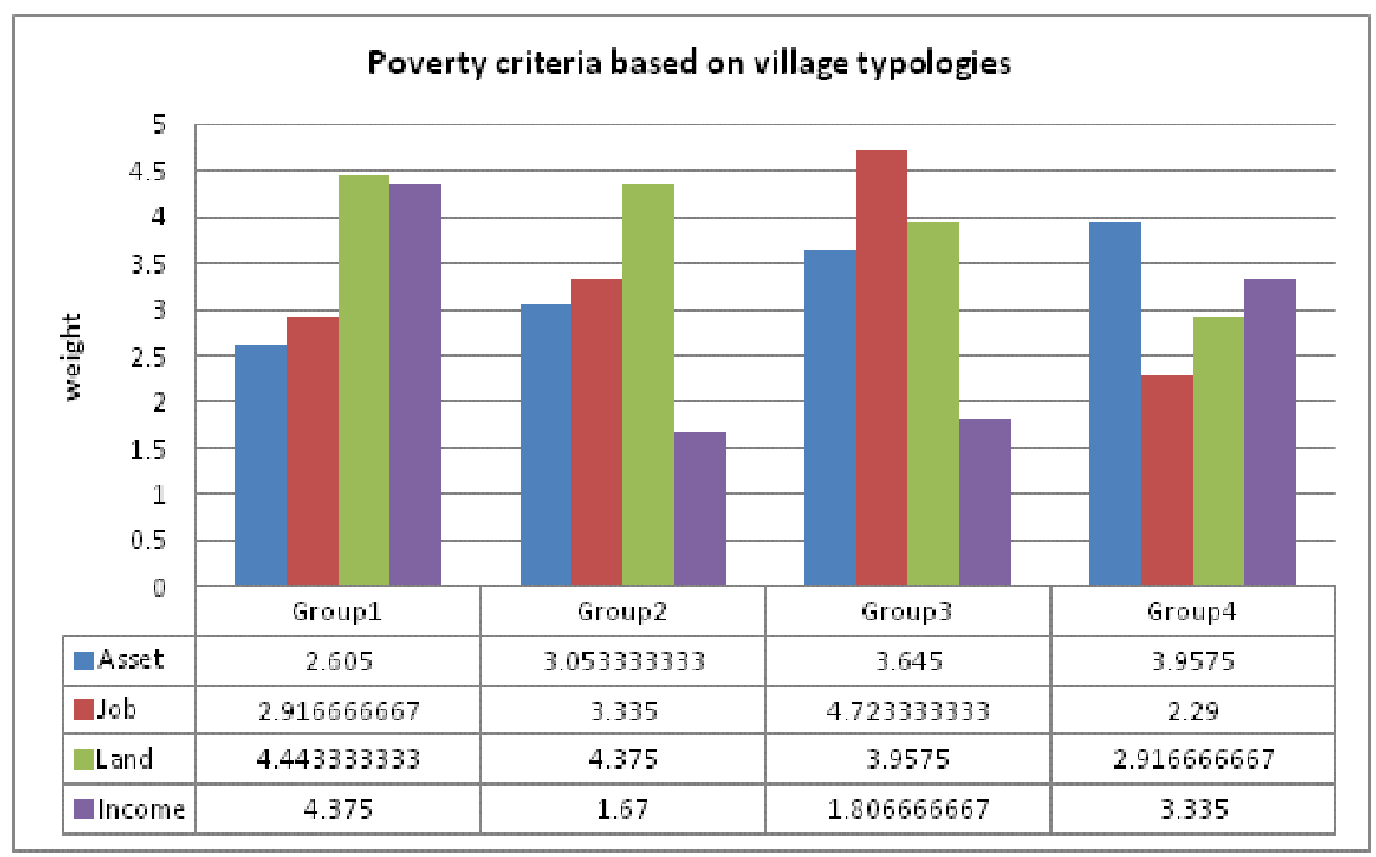

Figure 26. Criteria used to define well-being and/or poverty based on villages typologies. Data source: FGD. 
Based on local definitions of poverty, communities were asked to assess their own condition of poverty levels, both previously and today. The welfare pattern from the past to present in each group of communities was similar in each village. Interestingly, the figure shows that men generally rate their well-being as lower than the level that women rate their well-being, except in Kayu Loe (Figure 27). This might be due to technical aspects of the discussion processes in those two groups, or it might be due to other interesting factors related to gender matters. It would be interesting to analyse these issues more deeply to gain a comprehensive story of the relationship between well-being and gender issues.
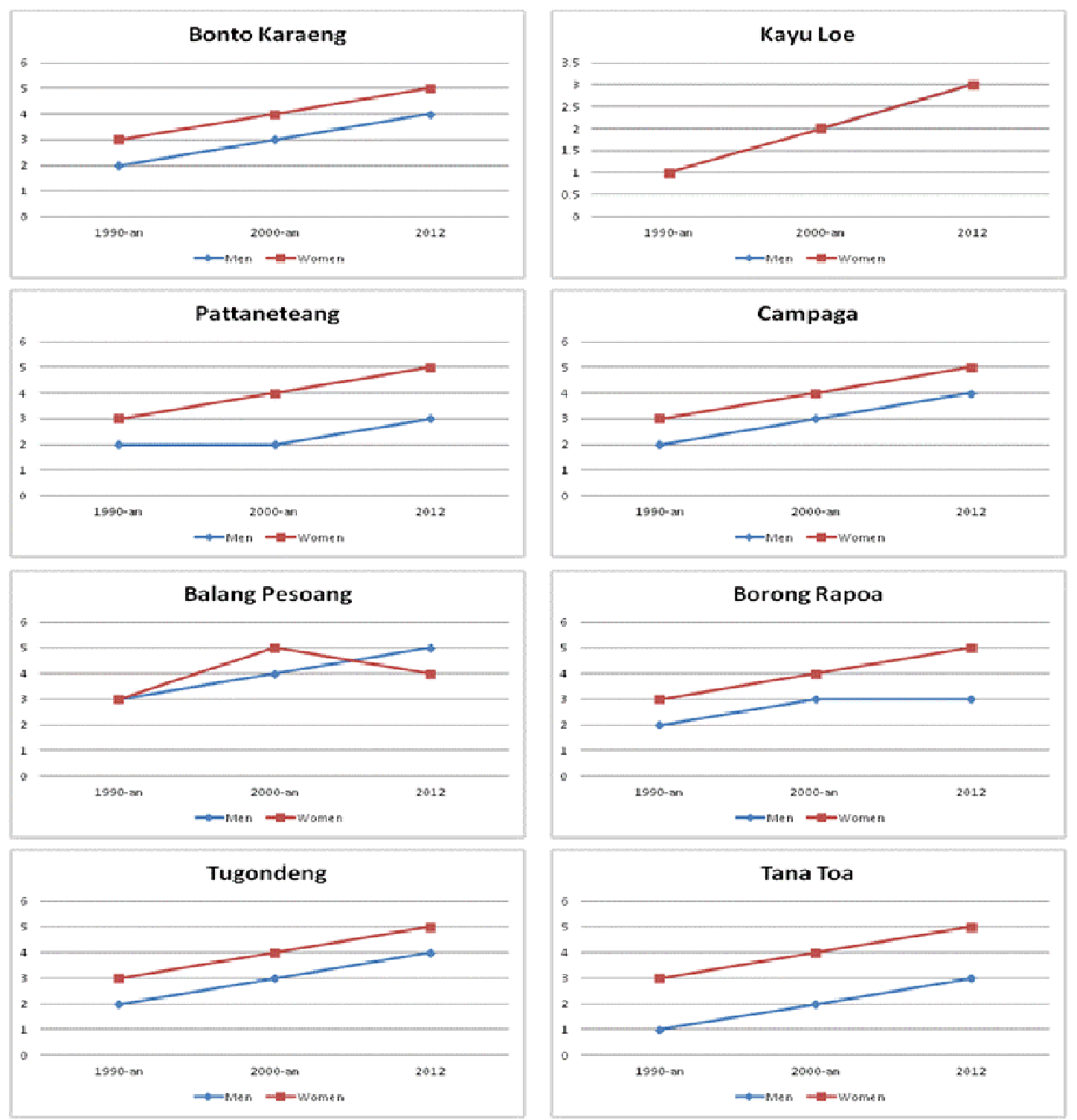

Figure 27. Male and female perceptions of their well-being and poverty status from 1990s to the present. Data source: FGD. 
A majority of the well-being status of the village displays the same trend of moving in one direction, with the current condition better than the previous. However, there are some exceptional cases such in Pattaneteang in 2000, Balang Pesoang in 2000, and Borong Rappoa in 2012. The causal factors are very site-specific, but we can summarize the factors that influence how people perceived their wellbeing status as listed below.

- Natural causes: pests/diseases, plants and farm production, harvest failure and natural hazards.

- External intervention: technology introduction, plantation and farming programs from government, electricity.

- Market pressure: price fluctuation.

\section{Gender, livelihood and land in Southeast Sulawesi}

\section{Gender and livelihood}

Women's roles in Southeast Sulawesi are mainly within the domestic tasks and the maintenance of homegardens, with men working mainly in the public sector. This study will elaborate upon how women have roles in land-based livelihood sources in rural communities. Our findings within this study can also explore how women are involved in natural resource management and in the public sector.

Mixed-garden and cocoa cultivation is the most important land-based livelihood source (Figure 28 and Table 11) for the community as well as specifically for women, as it provides a source of income and also meets their subsistence needs. The majority of the community practiced the mixed-garden system although the main commodity in each system was not always the same; usually coffee, cacao, and clove-based. Group discussions with participants in Group B and C unilaterally agreed that the mixed-garden system is the most important livelihood source for the community and specifically for women.

Irrigated paddy systems were also important in some villages such as Lamunde and Wanoa Hoa. In Wanoa Hoa, irrigated paddy systems were mainly found in the local people's settlement area (local village), while in the migrant settlement area the main farming system was cocoa-based. Many of these communities were monocultures with a few simple agroforestry systems. Horticulture plots were usually dominated by maize production and a main vegetable, such as long-bean or spinach. 
People without land were able to cultivate paddy and work in horticulture using a tenancy system or sharecropping/'deelbouw' (locally called 'tesang' or 'teseng'), usually at the rate of $50 \%$ to each of the two parties.

Off-farm work was important to every area and consisted of a range of activities including farm labour (on individual farms), company labour (on state or company plantations, or agricultural systems), farm labour (on other smallholder farming systems) and non-farm activities such as handyman/building work and transportation services. Company labour work was common in Lawanoa village, as it is located close to the large oil palm plantation Agrindo Mas Ltd.

Table 11. Livelihood source and its importance for a whole community and for women based on village typologies

\begin{tabular}{|c|c|c|c|c|c|c|c|c|c|c|}
\hline & \multicolumn{2}{|c|}{ Group A } & \multicolumn{2}{|c|}{ Group B } & \multicolumn{2}{|c|}{ Group C } & \multicolumn{2}{|c|}{ Group D } & \multirow{2}{*}{$\begin{array}{c}\text { Total } \\
\text { community }\end{array}$} & \multirow{2}{*}{$\begin{array}{c}\text { Total } \\
\text { women }\end{array}$} \\
\hline $\begin{array}{l}\text { Livelihood } \\
\text { source }\end{array}$ & Community & Women & Community & Women & Community & Women & Community & Women & & \\
\hline Farm labour & 5.95 & 3.63 & & & 7.14 & 1.43 & 8.75 & 3.75 & 6.75 & 3.21 \\
\hline $\begin{array}{l}\text { Tesang } \\
\text { (sharecropping) }\end{array}$ & 6.61 & 4.46 & 1.99 & 2.82 & 3.33 & 4.44 & 4.29 & 1.43 & 4.13 & 3.41 \\
\hline Forest & 5.58 & & 5.60 & 3.00 & & & 5.71 & 7.14 & 5.60 & 4.04 \\
\hline Teak garden & & & 3.77 & 4.77 & & & & & 3.77 & 4.77 \\
\hline Pepper cultivation & 5.44 & 4.88 & 4.50 & 4.87 & 6.59 & 7.30 & & & 5.37 & 5.48 \\
\hline Cocoa cultivation & 7.92 & 7.08 & 7.14 & 7.14 & 4.76 & 5.48 & 2.50 & 2.50 & 6.02 & 5.98 \\
\hline Horticulture & 3.63 & 6.31 & 5.31 & 6.11 & 5.56 & 5.56 & & & 4.87 & 6.12 \\
\hline Company labour & & & 7.22 & 6.67 & & & & & 7.22 & 6.67 \\
\hline $\begin{array}{l}\text { Irrigated paddy } \\
\text { field }\end{array}$ & 8.57 & 8.57 & 5.60 & 5.04 & & & & & 7.08 & 6.81 \\
\hline Homegarden & & & & & & & 5.45 & 7.23 & 5.45 & 7.23 \\
\hline Mixed-garden & 7.87 & 7.98 & 8.09 & 6.96 & 8.57 & 8.57 & 8.04 & 6.79 & 8.02 & 7.45 \\
\hline Grand total & 6.51 & 6.46 & 5.90 & 5.64 & 5.91 & 5.69 & 6.03 & 5.36 & 6.14 & 5.88 \\
\hline
\end{tabular}

Data source: FGD.

Figure 28 illustrates that women and men have slightly different opinions in defining the important livelihood sources for women and for the community. In Group A, both men and women argued that irrigated paddy fields, mixed-garden systems and cacao cultivation were important for both women and the community. The forest was not considered important for women but highly important for the community. The situation in Group B was slightly different, as while men considered farm activity to 
be most important both for women and the community, women argued that off-farm work (company labour, such as for an oil palm company) is an important livelihood source both for women and community as a whole. Discussions with the women and men's group's in Group C demonstrated that the forest was not considered an important livelihood source for either women or the community. In the discussions with Group D, the women didn't acknowledge that the forest is an important livelihood source for either women or the community, but the men's group did so.

The forest is still an important livelihood source for all of the three groups except Tasahea village, the long-established transmigration area. The forest has been traditionally an important source for the communities, providing honey, rattan, Arenga Pinnata starch for sugar production, and firewood or timber extraction. Currently, farmers still access honey, rattan and timber from the forest, but for Tasahea village, no forest exists in the surrounding area.

Tesang/sharecropping or tenancy systems were also found to be important livelihood sources, in all of the areas. Landless farmers cultivated paddy in surrounding villages depending on their location. For example, farmers in Wanoahoa village cultivated irrigated paddy in the nearby location of Lambuya village.

One of the reasons mixed-garden systems are important both for the whole community and for women is because the involvement of women is relatively high compared with men (Figure 29). A high involvement of women was also found in agricultural production such as within irrigated paddy field systems and horticulture cultivation. In relation to labour, women work largely within companies rather than in smallholder farming systems. The oil palm company workers are usually women, who undertake 'feminine' jobs of fertilizing and applying pesticide, and light weeding.

For both women and men in the whole surveyed area, the involvement of women in mixed-gardens was consistently rated highly, except in the discussion with the men in Group C. In Group D, although women's involvement in mixed-garden systems were considered high, their main role was found in the homegarden system, which also consists of mixed vegetation species. Group participants mentioned that due to the location of the homegardens surrounding the houses, women were able to manage their responsibilities of looking after family and small children at their house, while also practising agricultural production. In pepper cultivation, women's involvement was also considered high, with women involved in planting, maintaining the crops, harvesting, post-harvest processing, and marketing the product. 


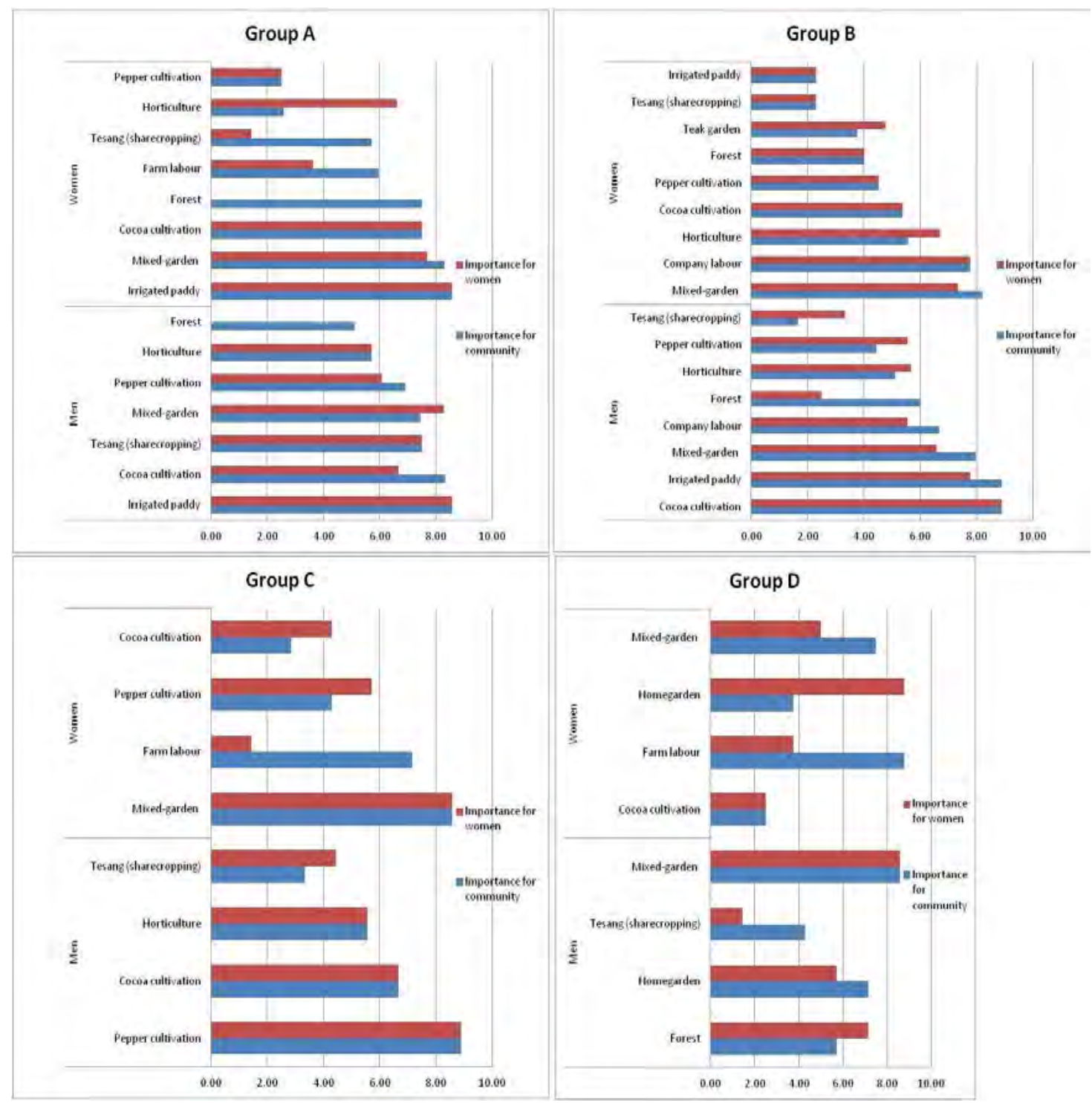

Figure 28. Livelihood source and its importance for the whole community and for women based on typology groups. Data source: FGD. 


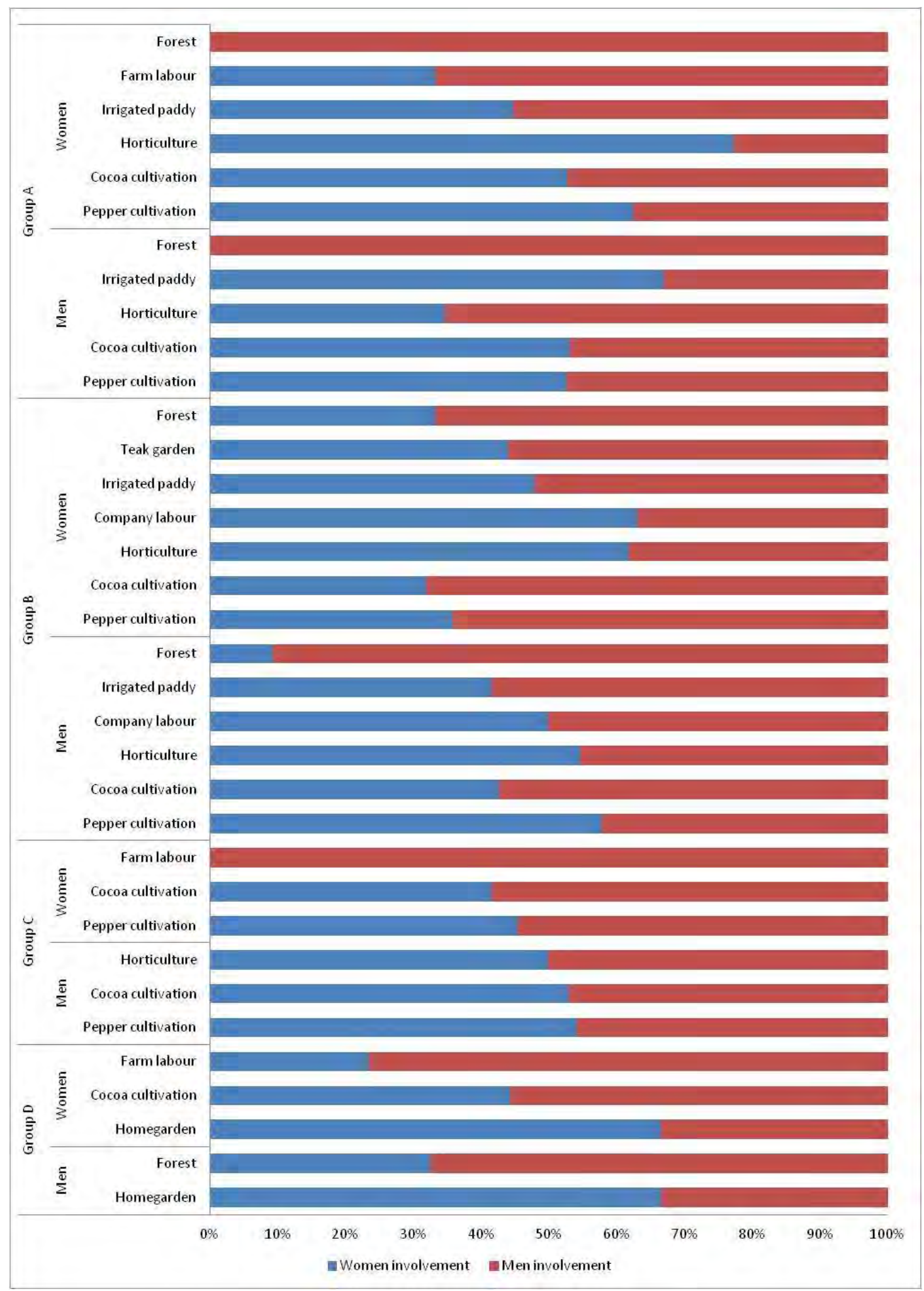

Figure 29. Gender involvement in livelihood source per village groups. Data source: FGD. 


\section{Gender roles in the household}

Household task division demonstrated similar results to other areas. Women were more responsible for tasks such as taking care of children, preparing food and ensuring that all family members have enough food, while men were more responsible for earning income and working in the public domain. Discussions with the community showed that women spent more time undertaking activities, while men had more leisure time in comparison (Figure 30).
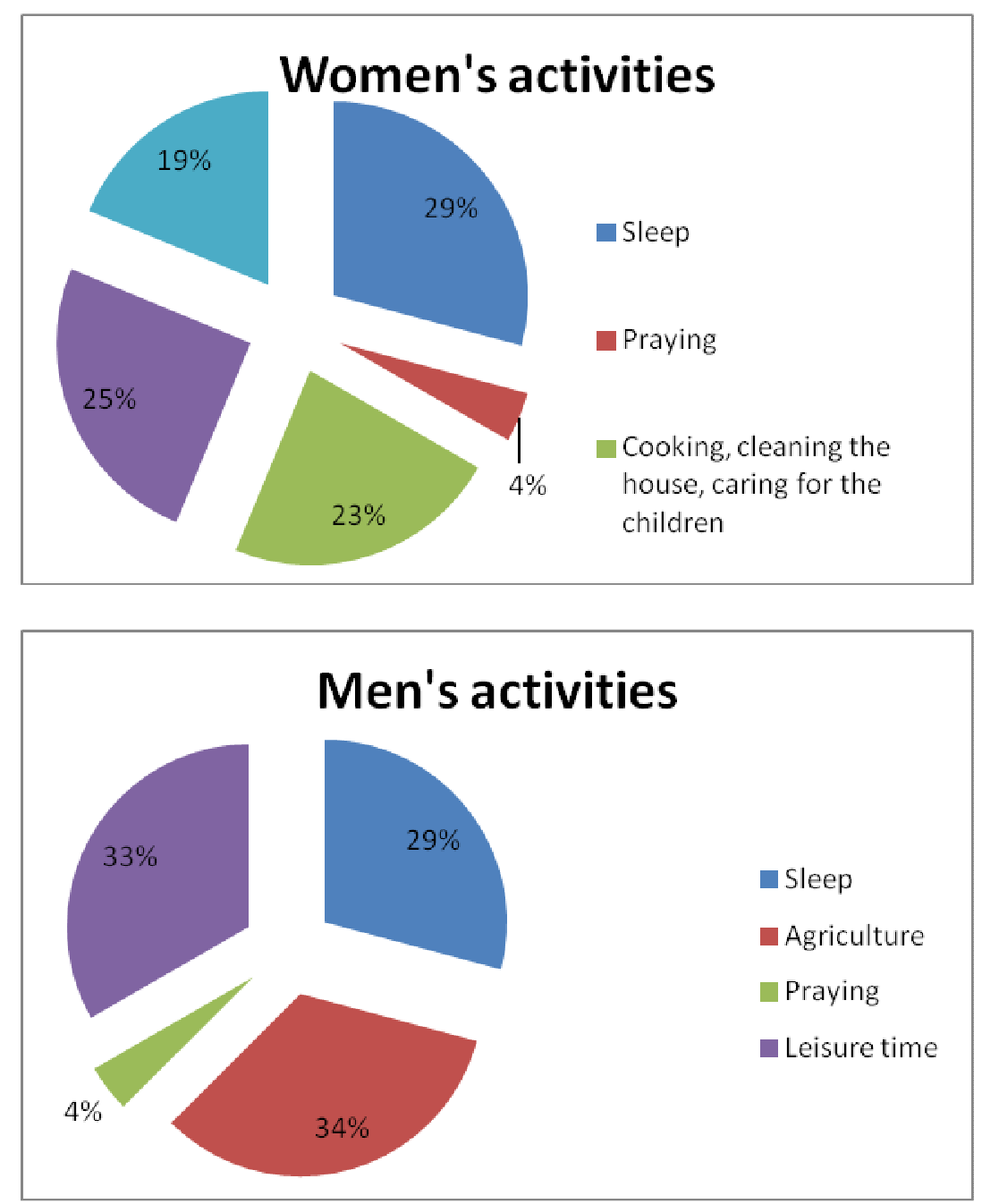

Figure 30. Women's and men's activities in the household. Data source: FGD.

\section{Gender roles in farming activities}

Women's roles in farming were relatively high in the areas of harvesting, post-harvesting, and marketing (

Figure 31), with men's roles high in clearing and preparing the land. Figure 32 shows gender roles in farming systems in Southeast Sulawesi based on household survey results. The data showed that 
women's involvement in farming system activities was prominent-always more than $80 \%$ in all of the surveyed villages, mainly in the areas of post-harvesting and marketing. Women were found to be working in harvesting at a relatively similar level to men. Other activities (land preparation, planting and crop care) were generally undertaken by men.

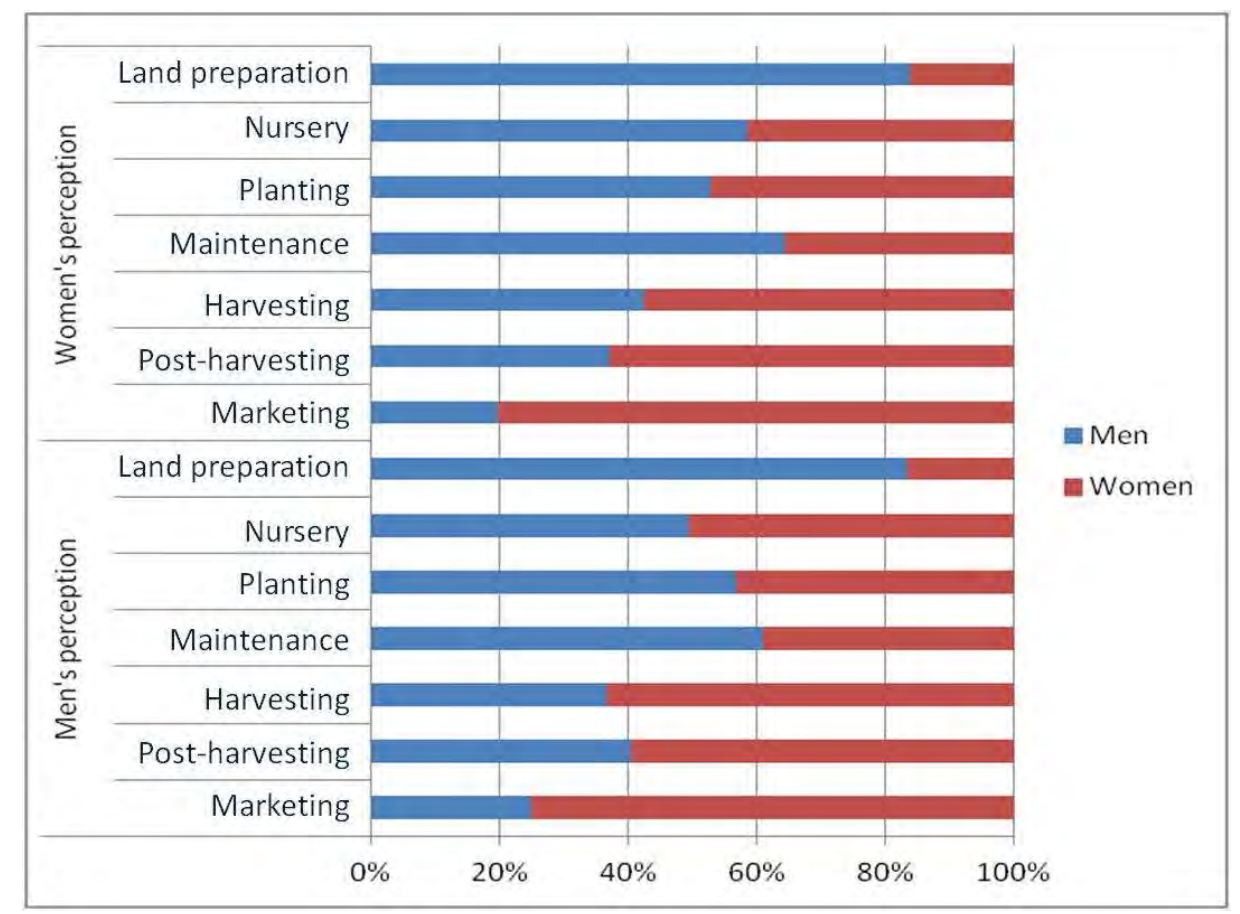

Figure 31. Gender roles in selected farming system activities in whole study area. Data source: FGD.

Similar patterns were found in agroforest ('kebun campur') production, irrigated paddy field cultivation, and vegetable production (Figure 33 and Figure 34). The one contrasting case was in relation to nursery activity for irrigated paddy field cultivation which men argued very few women are involved in, while women indicated that they are involved in this activity at approximately $20 \%$. 


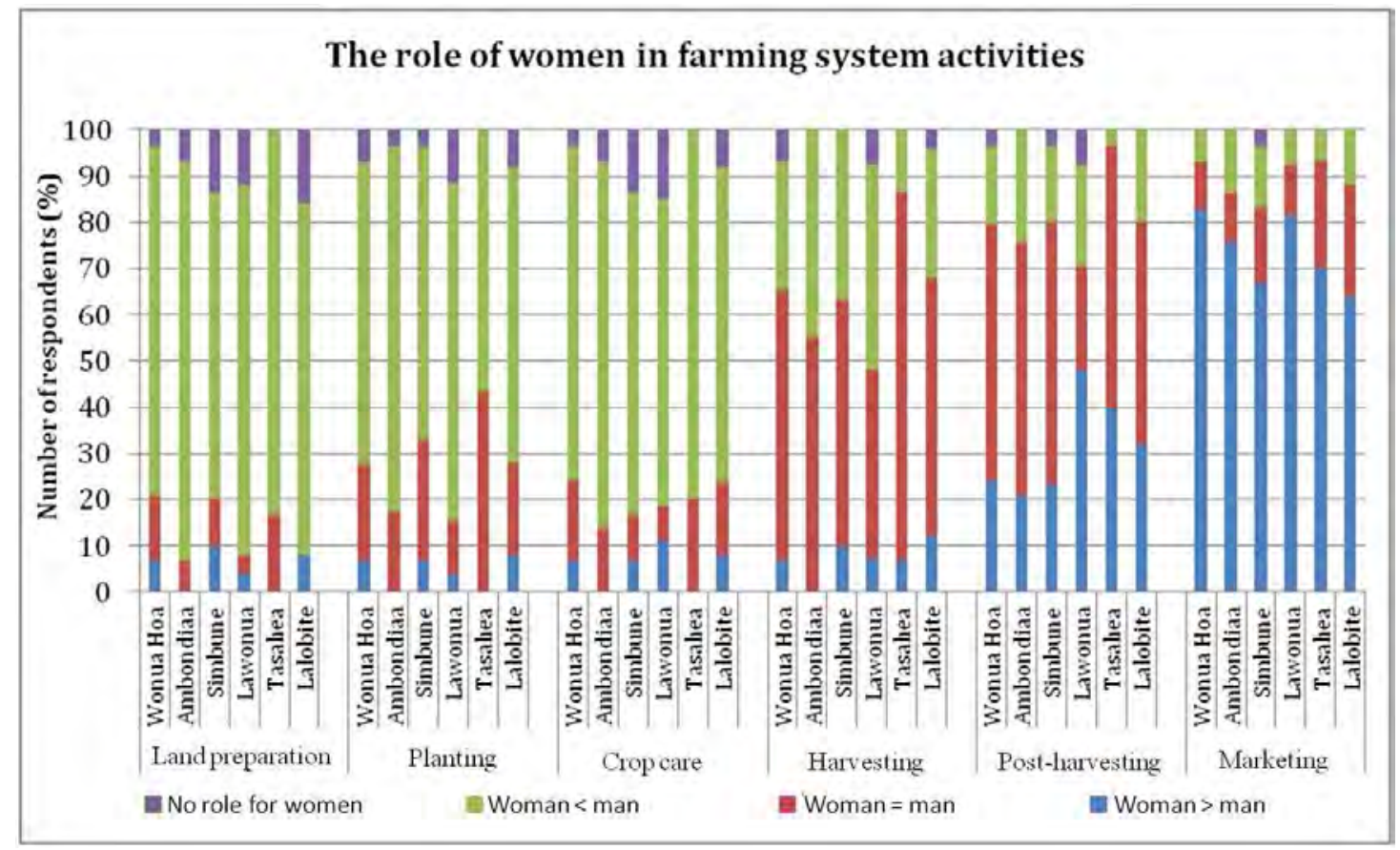

Figure 32. The role of women in farming system activities in Southeast Sulawesi.

Data source: Household surveys.

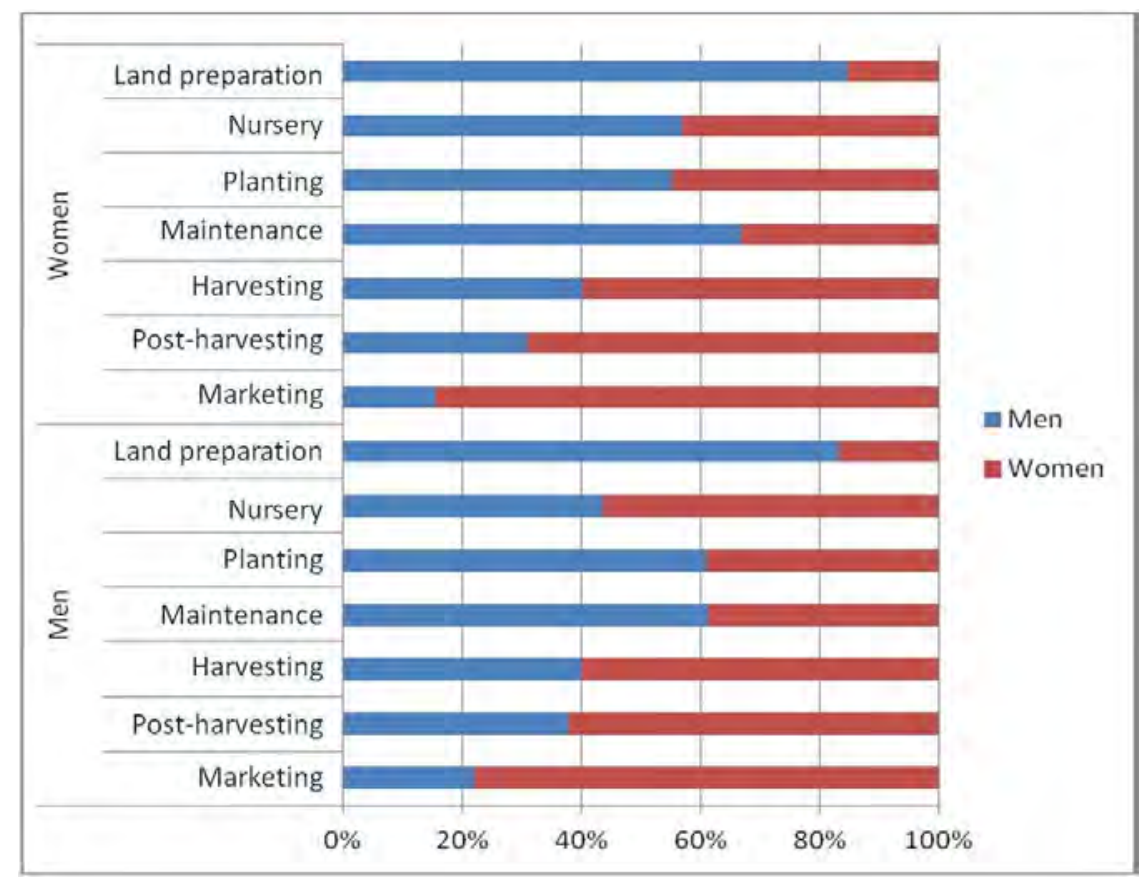

Figure 33. Gender roles in traditional agroforestr. Data source: FGD. 


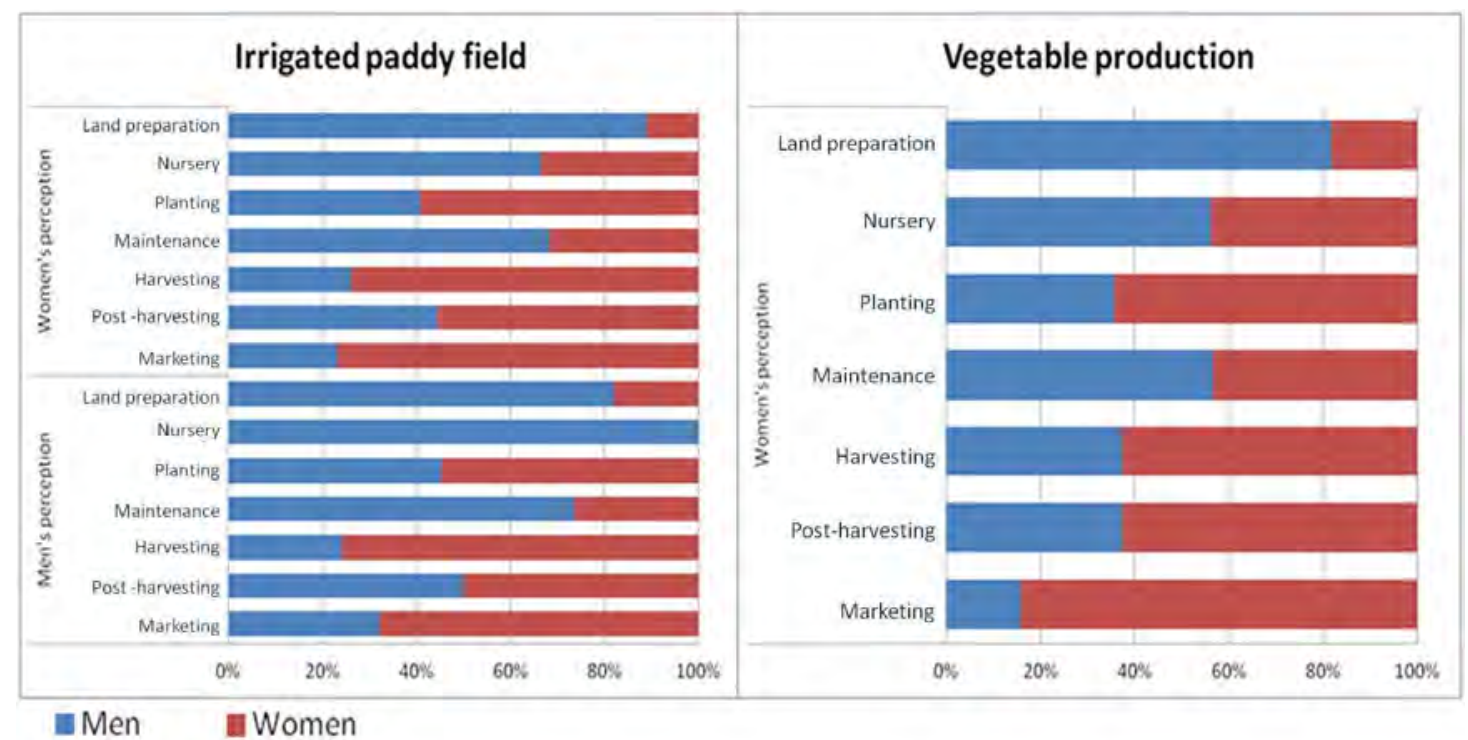

Figure 34. Gender division of tasks in vegetable production and irrigated paddy field cultivation.

Data source: FGD.

In work related to the forest, women's roles were relatively high in both vegetable and pandanus collection. In Anggawo village, pandanus was an important livelihood source, used as a raw material for making traditional floor mat ('tikar'). Although women also had the responsibility of collecting pandanus from the forest their role was mainly to support the men. The men's responsibilities included extracting timber, collecting rattan and honeybees. Differences between male and female perceptions of the forest work were not found to be very significant. One interesting finding was that when we discussed gender roles in timber extraction, women argued that they contribute to this work, but the men did not acknowledge this. The women's group considered that female-headed households produce timber, but the men did not account for this. This is perhaps due to the fact that while women may not be involved physically in timber production, the women considered their decision-making powers in relation to timber being harvested, as an important role. 


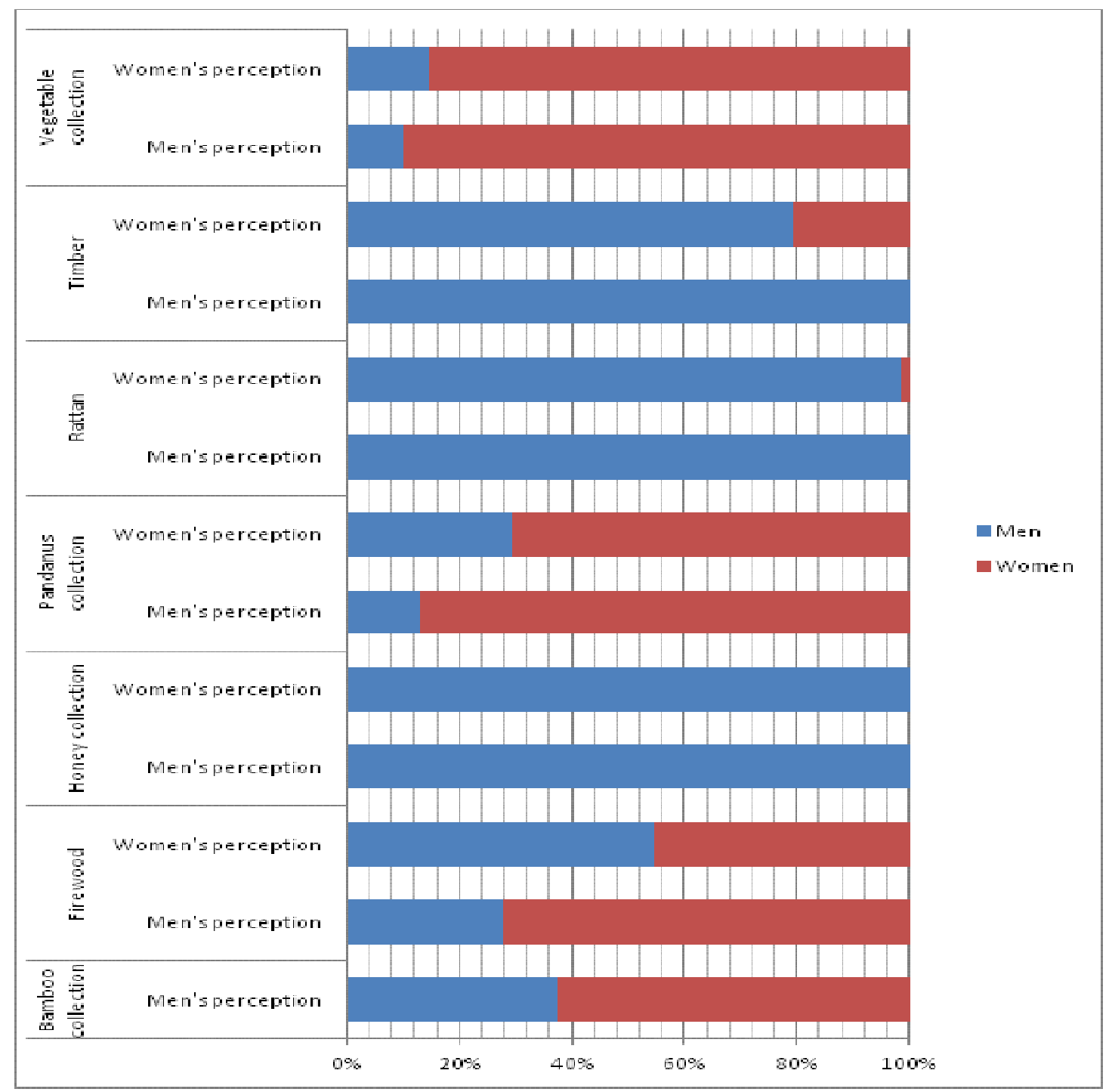

Figure 35. Gender division of tasks in forest. Data source: FGD.

\section{Land and gender}

The ownership of land as based on gender was an important discussion topic in order to identify gender issues of equality and equity within natural resource management. Gendered perceptions of the importance of land use for livelihood and the environment were important be identified, as this information can inform how women and men are involved in land management.

\section{Land ownership}

In the surveyed villages, land holding per household averaged at 3.39 ha of the total area (Janudianto 2013). Cacao Agroforest was an important land use for the community in most areas, with each household having approximately $0,5-2,0$ ha (Table 12). Mirroring the situation in South Sulawesi, land ownership usually belongs to husbands or men (Figure 36) in Southeast Sulawesi. The data from 
the Janudianto (2013) showed that $42 \%$ of plots were owned by a husband, and $42 \%$ owned by a husband and wife together. Only $12 \%$ of plots were owned by wives. Wives or women were only able to own the land, or have their name on the land certificate, if they inherited the land from their parents. Whenever the local community obtained the land by buying it, the name on the certificate was supposed to be the husband, as the family head.

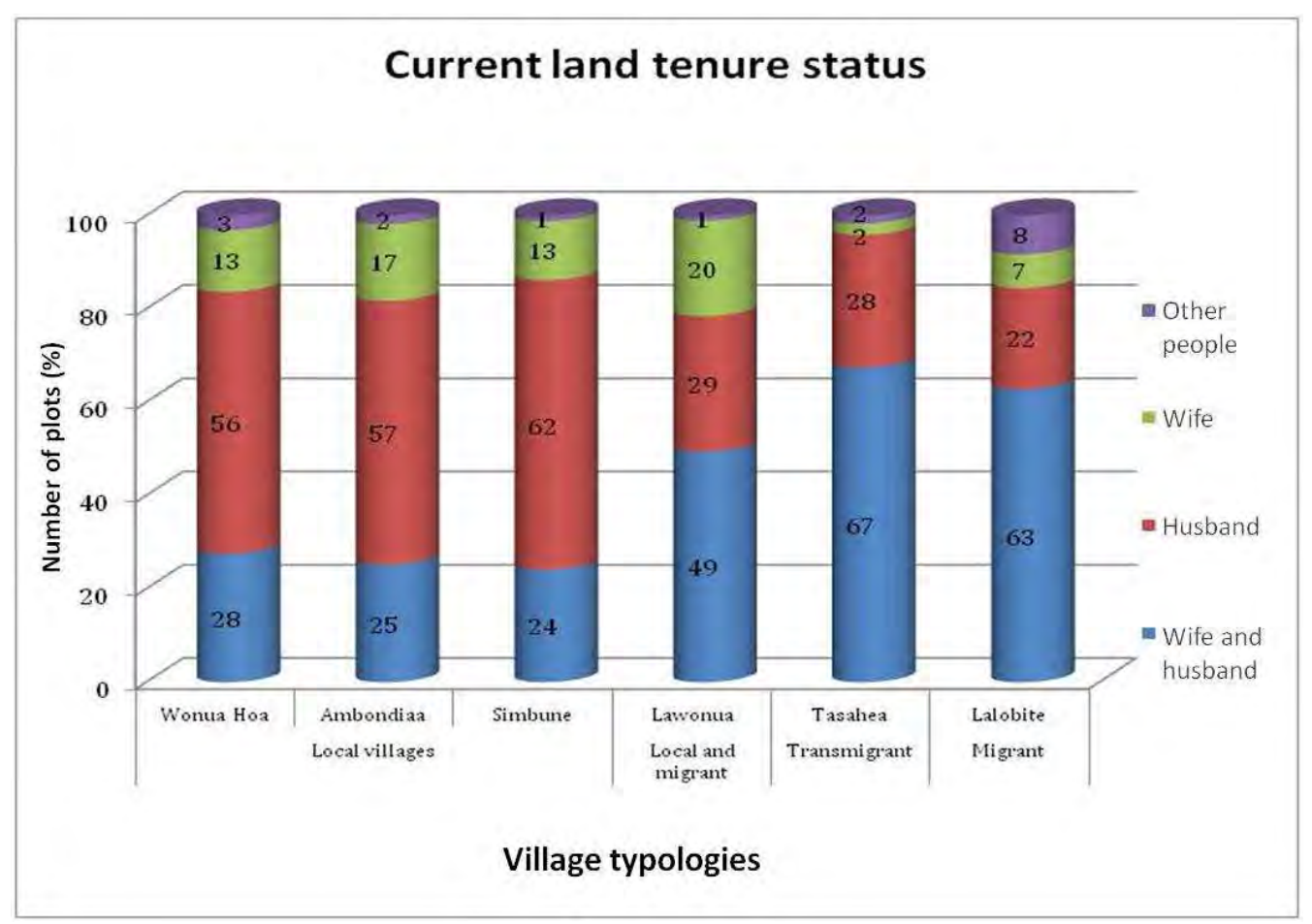

Figure 36. Current land tenure status in Southeast Sulawesi. Data source: Janudianto 2013

Table 12. Land holdings in surveyed villages in Southeast Sulawesi

\begin{tabular}{|c|c|c|c|c|c|}
\hline & $\begin{array}{l}\text { \%Land } \\
\text { holders in } \\
\text { village }\end{array}$ & $\begin{array}{l}\text { Average } \\
\text { area in each } \\
\text { villages }\end{array}$ & $\begin{array}{l}\text { Who owned the } \\
\text { land? (listed on } \\
\text { land certificate) }\end{array}$ & $\begin{array}{l}\text { Who has the } \\
\text { right to inherit } \\
\text { land? }\end{array}$ & $\begin{array}{l}\text { Who has the } \\
\text { right to manage } \\
\text { the land? }\end{array}$ \\
\hline $\begin{array}{l}\text { Mixed- } \\
\text { gardens } \\
\text { Anggawo }\end{array}$ & 80 & $2-4$ ha & \multirow{9}{*}{$\begin{array}{l}\text { Men (could also } \\
\text { be women if } \\
\text { they inherited } \\
\text { the land) }\end{array}$} & \multirow[t]{9}{*}{$\begin{array}{l}\text { Men and } \\
\text { women }\end{array}$} & \multirow[t]{9}{*}{$\begin{array}{l}\text { Men and women } \\
\text { (owner) }\end{array}$} \\
\hline Simbune & 95 & $0.5-2$ ha & & & \\
\hline Lawonua & 25 & $0.5-2$ ha & & & \\
\hline Tasahea & 95 & $0.5-5$ ha & & & \\
\hline Taosu & 75 & $0.5-6$ ha & & & \\
\hline Lamunde & 75 & $0.5-2$ ha & & & \\
\hline Wanoa hoa & 80 & $0.3-1$ ha & & & \\
\hline Ambondiaa & 75 & $0.5-1$ ha & & & \\
\hline UPT Asinoa & 95 & $0.5-1$ ha & & & \\
\hline
\end{tabular}




\begin{tabular}{lllll}
\hline $\begin{array}{l}\text { Irrigated } \\
\text { paddy fields }\end{array}$ & & $\begin{array}{l}\text { Men (could also } \\
\text { be women if } \\
\text { they inherited it) }\end{array}$ & $\begin{array}{l}\text { Men and } \\
\text { women }\end{array}$ & $\begin{array}{l}\text { Men and women } \\
\text { (owner }\end{array}$ \\
\cline { 1 - 3 } Taosu & 10 & $0.5-2$ ha & \\
\cline { 1 - 3 } Lamunde & 70 & $0.5-2$ ha & \\
\cline { 1 - 2 } Wonuahoa & 75 & $0.5-1$ ha & \\
\hline
\end{tabular}

Source: FGD.

\section{Men and women's perspectives of land use}

Local perceptions of land use systems and their functions were identified by using a scoring 'Exercise 100 ' button. The community assigned the buttons to each land use and their functions, which were identified prior to the discussion. There were three games within this activity: the community members were first asked to weight land use values based on their function in relation to livelihood and environment, and then they asked to weight the function of each land use.

Relatively similar to the results in South Sulawesi, the function of the land use types of agroforestry, irrigated paddy and upland paddy systems, were valued most for livelihood, while forest was most valued for its environmental function. Both the men and women's group discussions showed the same patterns in answers. Figure 38 shows that each village typology also displayed the same pattern of answers, with the forest most highly valued for its environmental function, irrigated and upland paddy field systems for their livelihood function, while mixed-garden or local agroforestry systems were valued both for environmental and livelihood functions, although livelihood was rated slightly higher than the environment.

The use of mixed-garden systems as an income source and to fulfil basic subsistence need was valued higher than other functions (Figure 39 and Figure 40). Both men and women's groups described the function of mixed-gardens as an income source, from economic commodities such as cacao, coffee, clove and candlenut. Subsistence need as provided by vegetation used for daily consumption such as from fruit trees including rambutan, candlenut, and sago. 


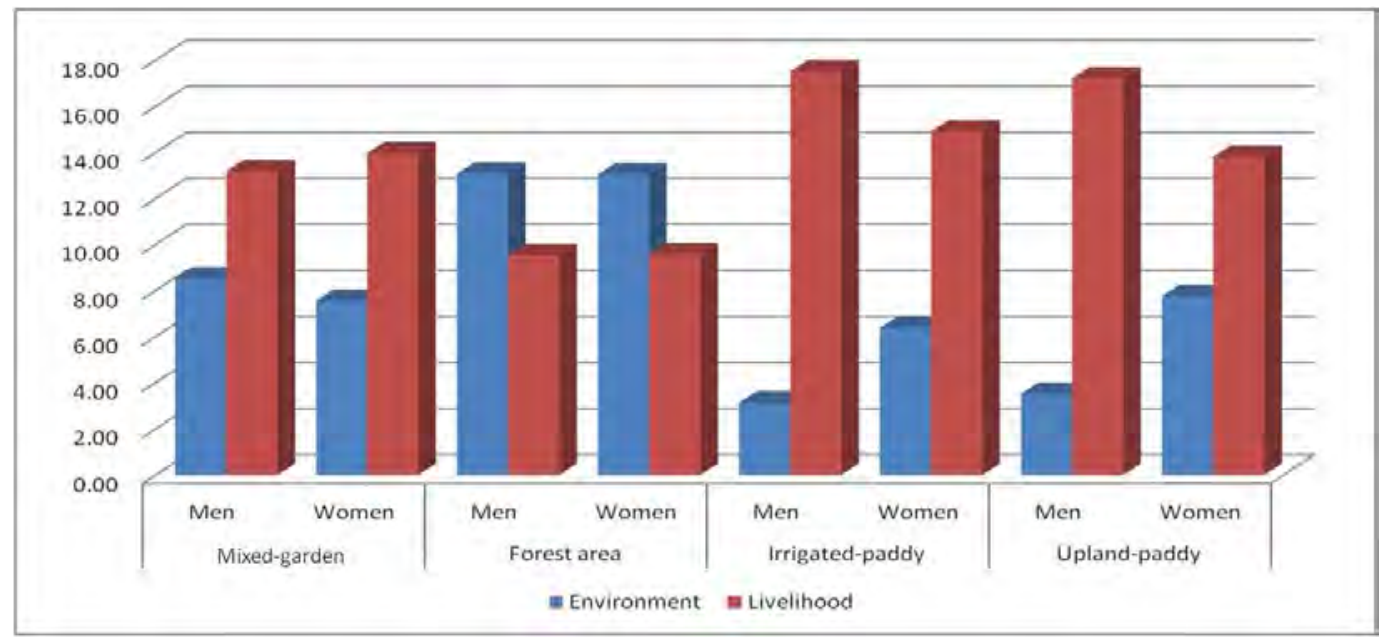

Figure 37. Livelihood and environment functions of each land-use system from male and female perspectives. Data source: FGD.

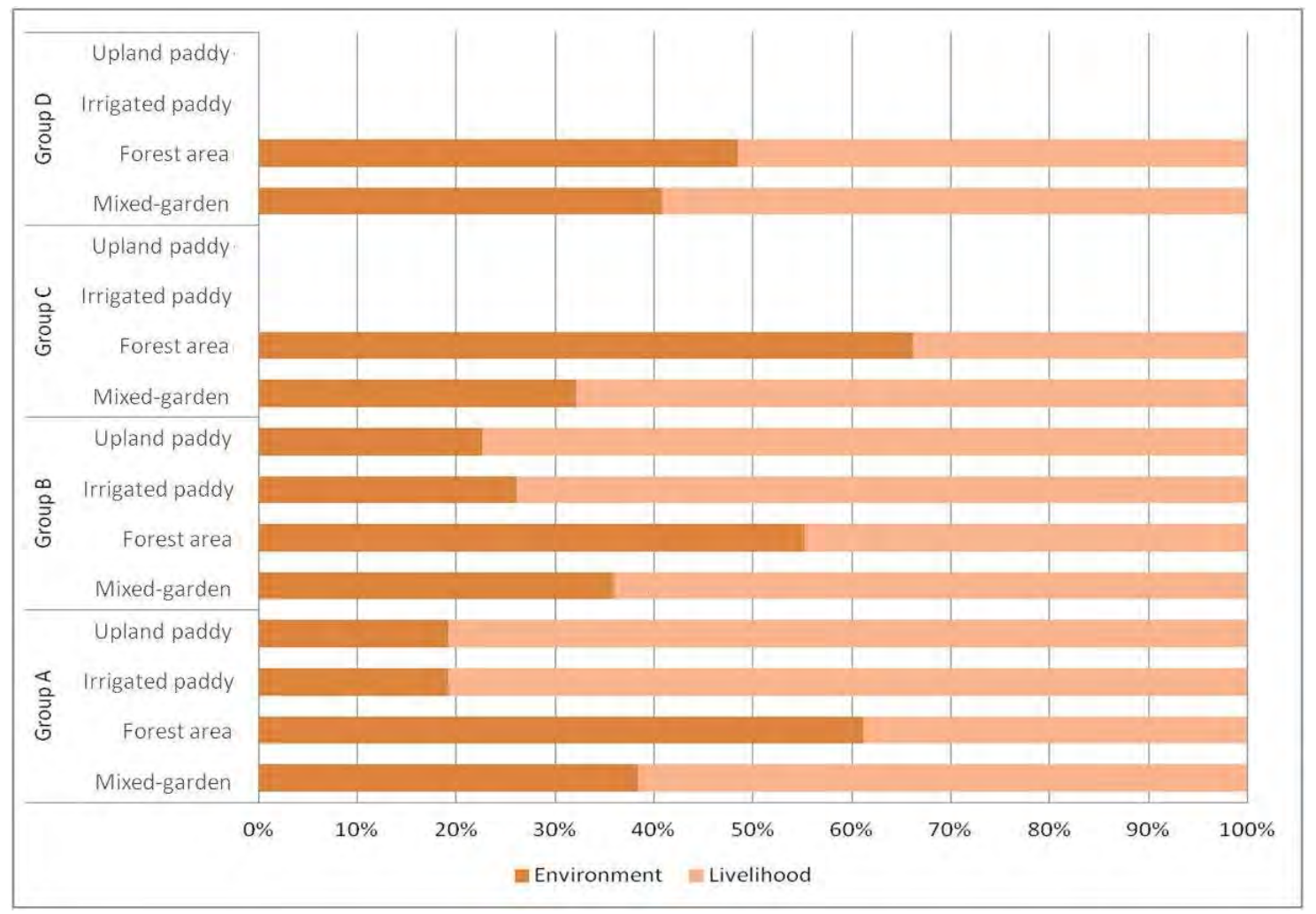

Figure 38. Livelihood and environment functions of each land-use system based on village typologies.

Data source: FGD. 


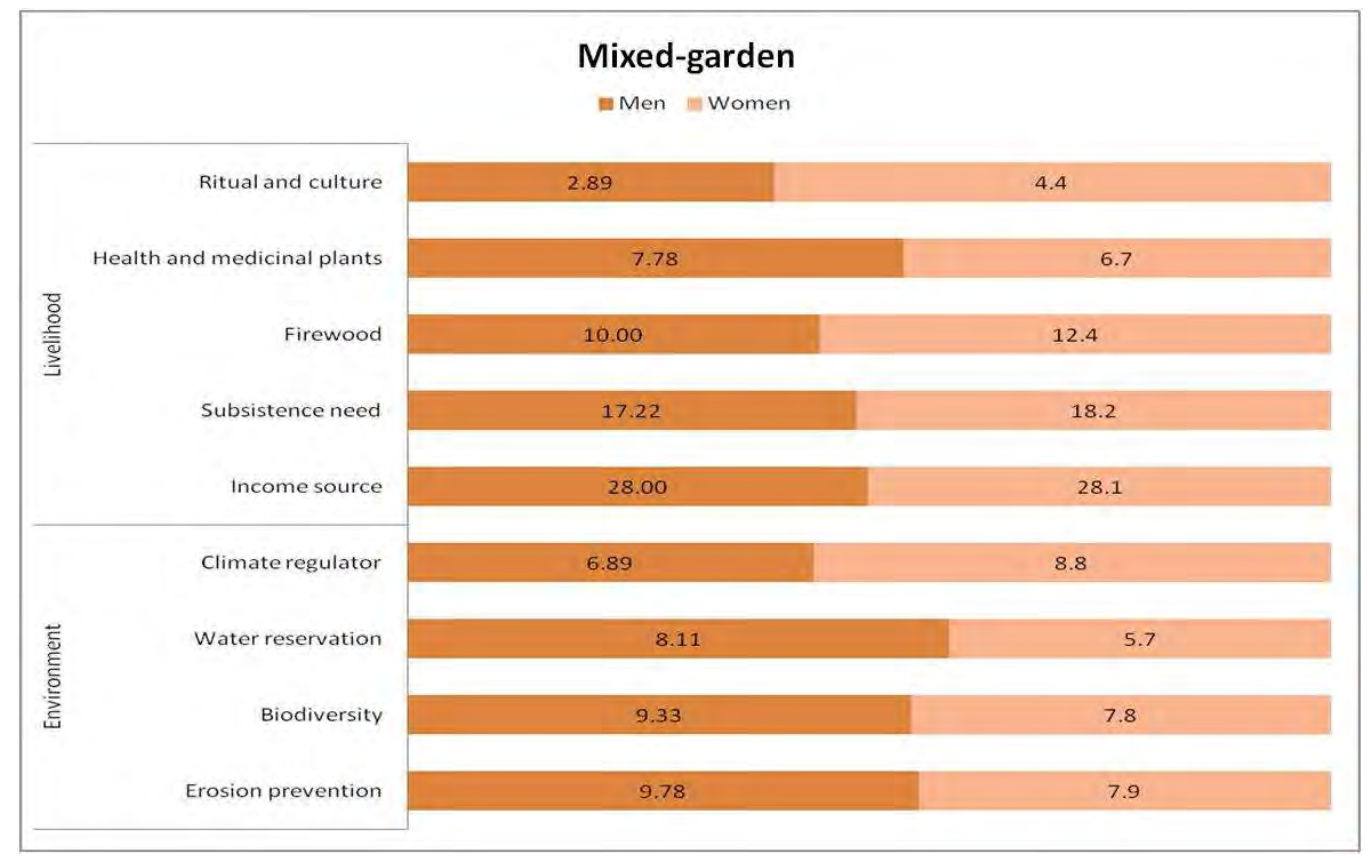

Figure 39. Gender perceptions of the importance of mixed-garden systems. Data source: FGD.

Irrigated paddy fields were valued highly in terms of their livelihood function. Observations during the discussions showed that both the men and women's groups found it difficult to value this system in term of its environmental function (Figure 41). This is due to the fact that they don't possess a thorough understanding of the value of water and land conservation, and climate regulation issues, with their answers sometimes being mixed up. However they fully comprehended biodiversity, which demonstrates that although the irrigated paddy system contain one main crop, it also consists of other vegetation nearby such as miscellaneous types of grass and trees, as well as animals found within the field.

As consistent with the findings previously analysed, the forest was always valued the highest in relation to the environmental function, both in the women's and men's groups (Figure 38, Figure 42). The community valued mixed-gardens as the highest land use for providing a source of income and fulfilling subsistence need, followed by irrigated paddy fields (Figure 43), which is also important for cultural/ritual functions. The forest was the main source for firewood, but mixed-gardens also provided an important land use by fulfilling community needs for fuelwood. 


\section{Mixed-garden}

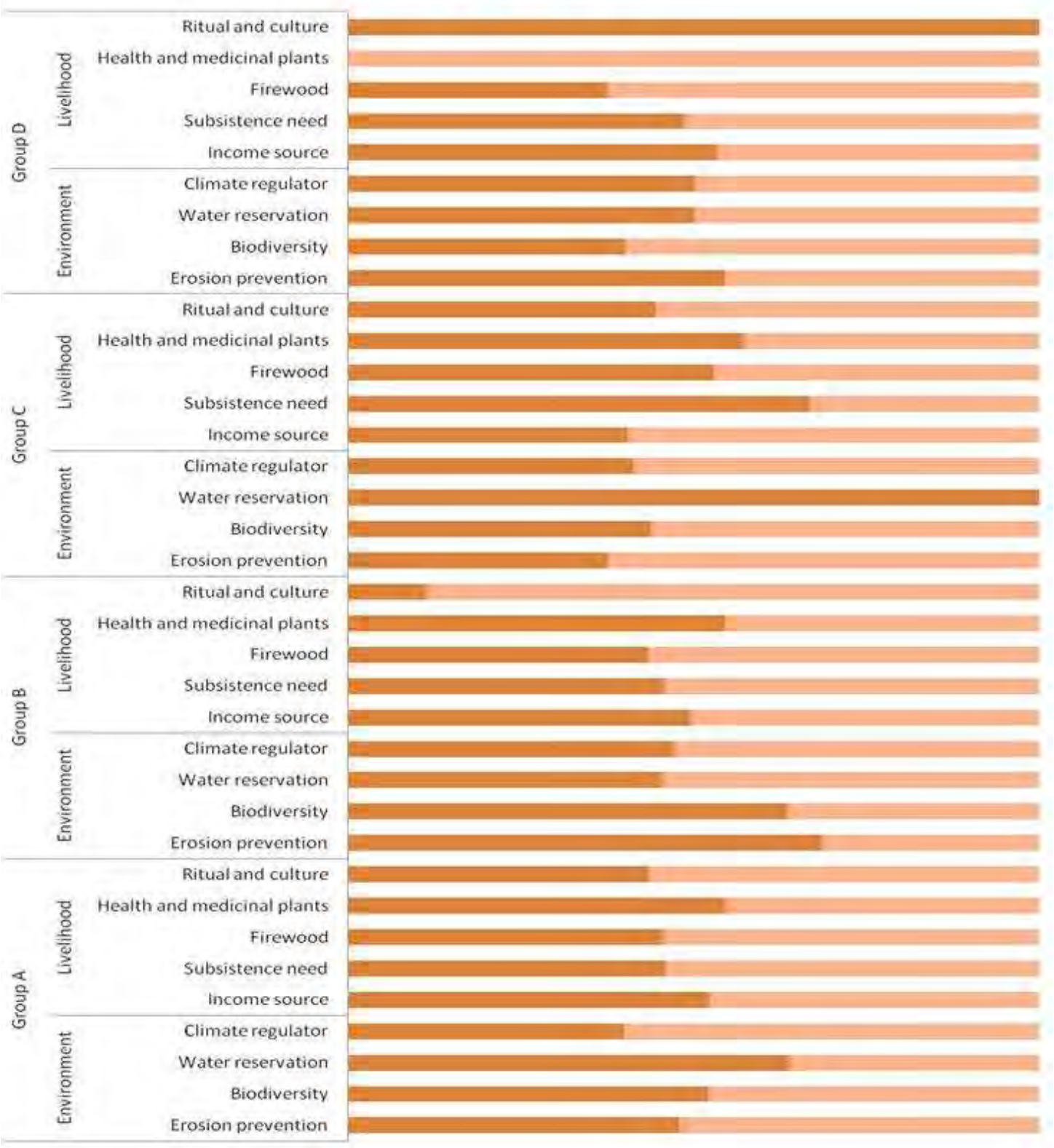

Figure 40. Perceptions of the value of mixed-gardens in each village typology. Data source: FGD. 


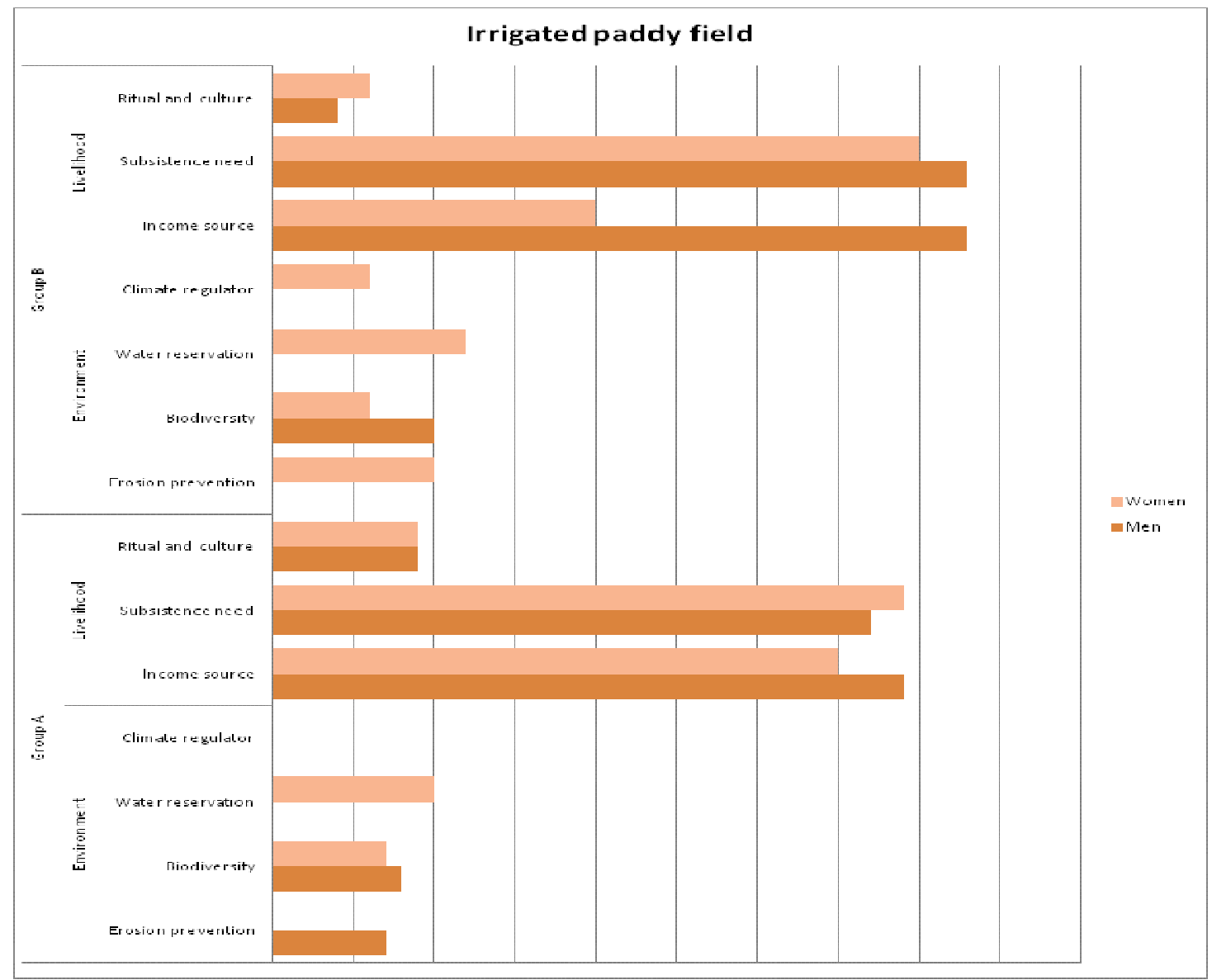

Figure 41. Gendered perceptions of the value of irrigated paddy fields. Data source: FGD.
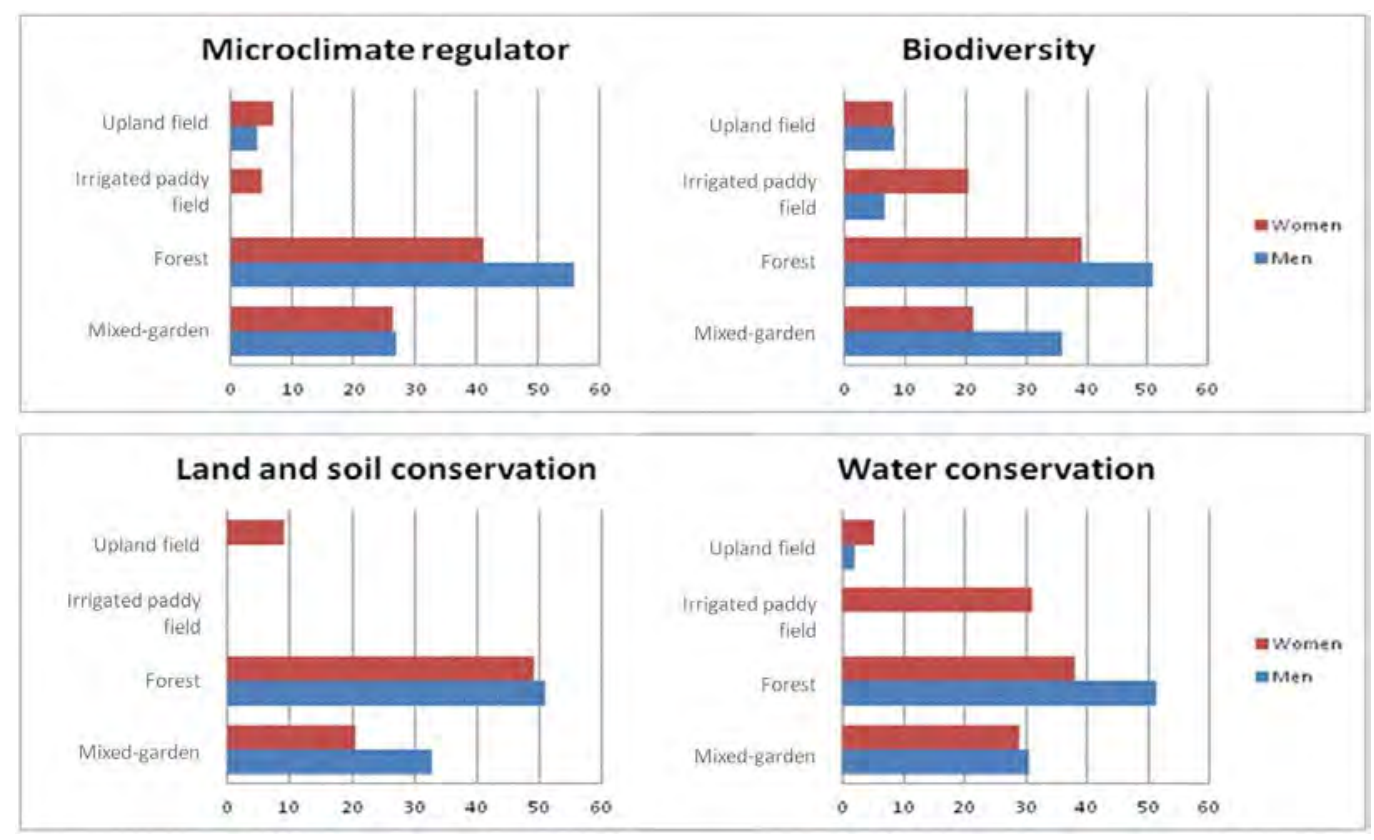

Figure 42. Perceptions of environmental value of the land us. Data source: FGD. 


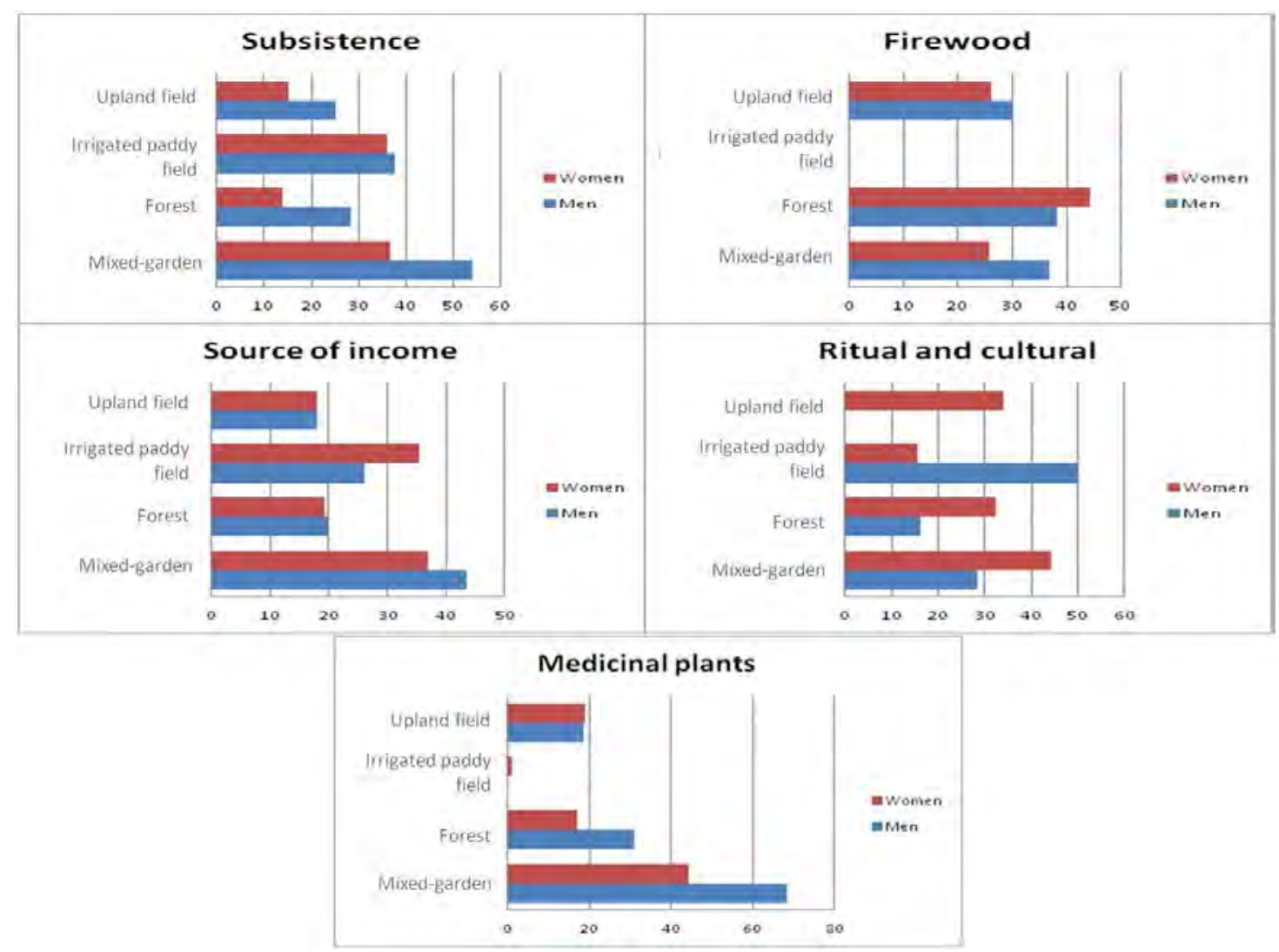

Figure 43. Perceptions of livelihood values of land use. Data source: FGD.

\section{Gender and the market}

The market discussed within this paper largely refers to the household level, focusing on the role of farmers as producers, existing as the entry point to the market chain. Within the household, women and men are involved in marketing, with women responsible for vegetables, paddy and select high market value commodities as cacao, candlenut, clove, and coffee, and men for timber commodities such teak, gmelina, and rattan (Figure 44). Women are usually responsible for marketing farm commodities from around their house and settlement area, while men market products either extracted from the forest or heavy in weight (such as timber). Women described the timber trade as men's domain as women don't have knowledge regarding the estimation of timber volume, and because they may need to travel to the field or forest to make the transactions. Women are more responsible for marketing products near to the house as local traders usually come to the house to make transactions and select the commodities. Therefore, women were still able to manage their household responsibilities and market their farm products. 


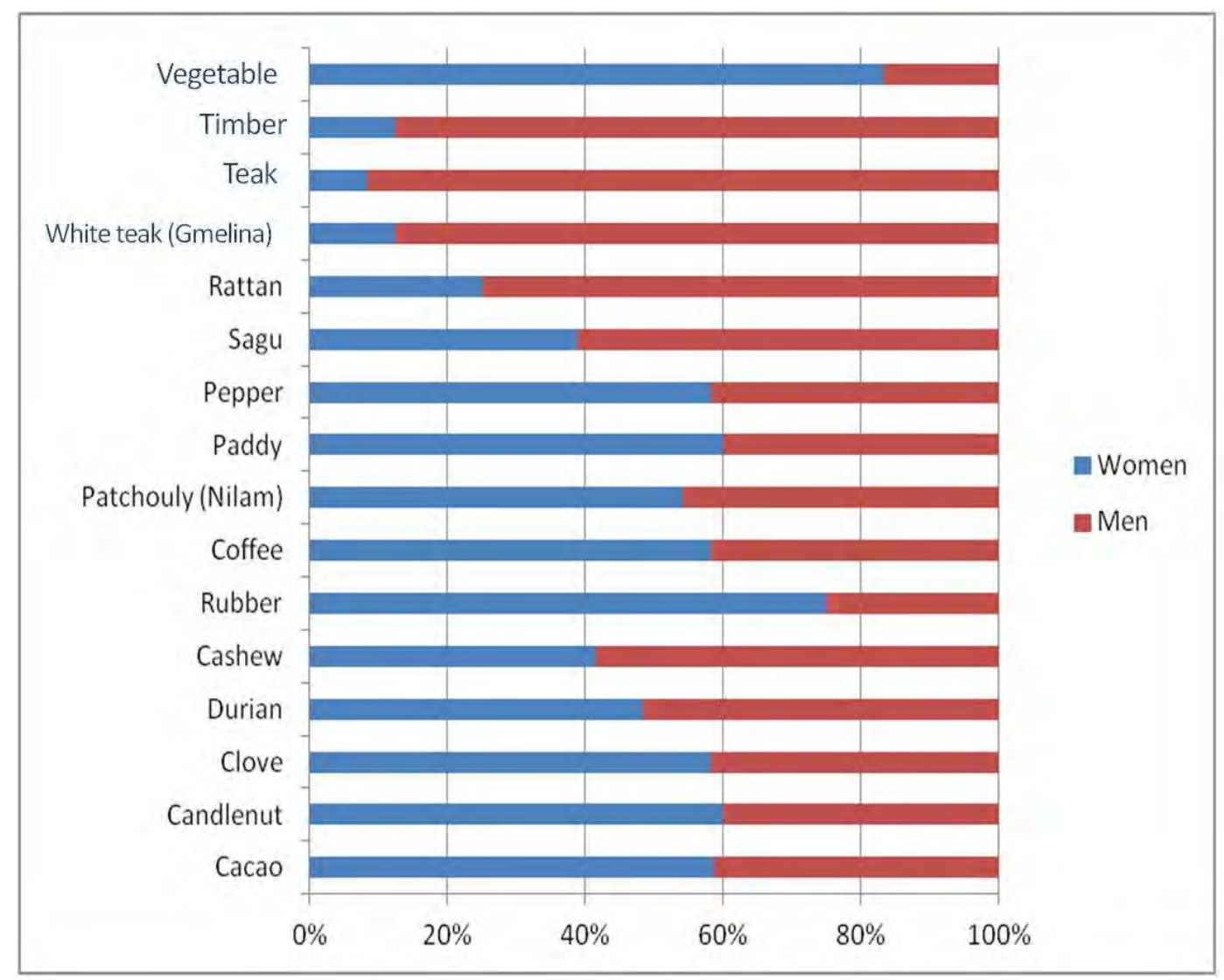

Figure 44. Gender roles in the marketing of common commodities. Data source: FGD.

In making transactions with local traders, both the men and women's groups agreed that women possess superior skills in negotiating price compared with men. However, regarding timber and rattan, due to lack of information about price fluctuation and assessing the value of timber, men have a better chance to obtain a good price. Interestingly, in terms of rattan, the group discussions in some villages (Ambondia, Wanoahoa, and Simbune) suggested that women were able to get higher prices than men, but the involvement of women in rattan marketing was still low. However, it is important to note that although women may possess good skills in bargaining price, they still have a lack of information about the price fluctuation. Traders usually relate the price to the quality of products but producers (farmers) possess very limited information about how to produce the high quality products.

\section{Gender and poverty}

In order to define poverty in the effort to alleviate it, an important step is gaining an understanding of how people perceive poverty. Most poverty alleviation programs use criteria developed from general and standardized indicators, which sometimes do not match with local conditions. A consideration of poverty must expand upon income and expenditure dimensions, to consider others that might be more 
relevant within the local context. Moreover, poverty must be defined based on people's wants and needs and not seen simply as the process of deprivation and relation among the poor and non-poor. Defining poverty based on local perceptions is an important stage in defining local criteria and indicators to identify and design interventions. It can capture the multidimensional aspects of poverty and the processes within it. Poverty definition was used to assess the current condition of communities, to analyse levels of their well-being. In discussions, farmers were asked to define the criteria they would use to differentiate conditions of poverty or well-being. The criteria described below is summarized from these discussions.

- Income

- Do not have permanent job

- Do not have proper land for farming

- Land size less than 0.5 ha per household

- Do not have land

- Do not have proper house

- Quality of house - from bamboo, round timber, etc

- Do not have house

- Do not have assets

- Vehicles

People without a certain income and/or job were categorized as the very poor. For the minimum, people require an income of approximately IDR 1 million per month to reach the lowest category of well-being. People with an income below that are categorized as poor. A job was important to indicate well-being. People without a job providing income were defined as lazy-sometimes having land and resources, but because they don't use them for income generation, they become poor. For the third category, land was also important to indicate well-being. People with limited land (less than 0.5 ha) were categorized as poor. The fourth category referred to house and assets, such vehicles. People with houses in poor condition (bamboo wall, thatch roof, and soil floor) were categorized as poor. And, in some areas, people without motorcycles were also defined as poor, although if they might have a good house. 


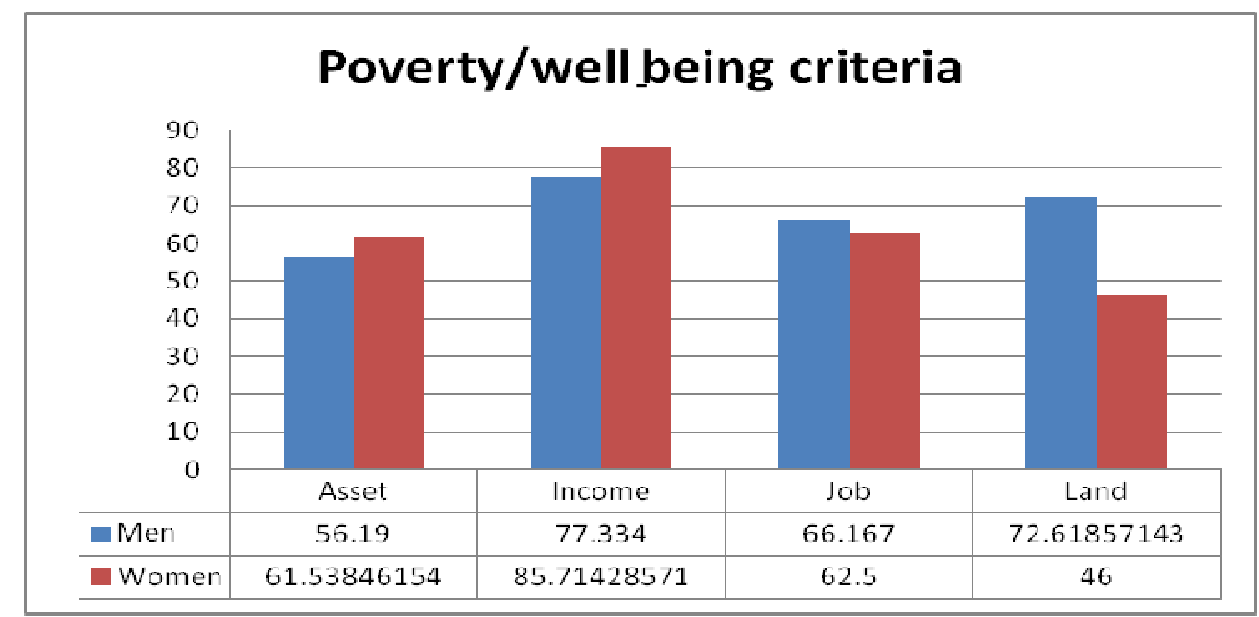

Figure 45. Criteria use to define well-being and/or poverty based on gender perspectives. Data source: FGD.

The difference between women and men in defining poverty criteria is presented in Figure 46. Both women and men agreed that income is the first criteria to define well-being, although women placed higher value upon this criteria. Men perceived that land was the second criteria in defining well-being. Women argued that job and assets were more important to define well-being, while land holding was considered less important.

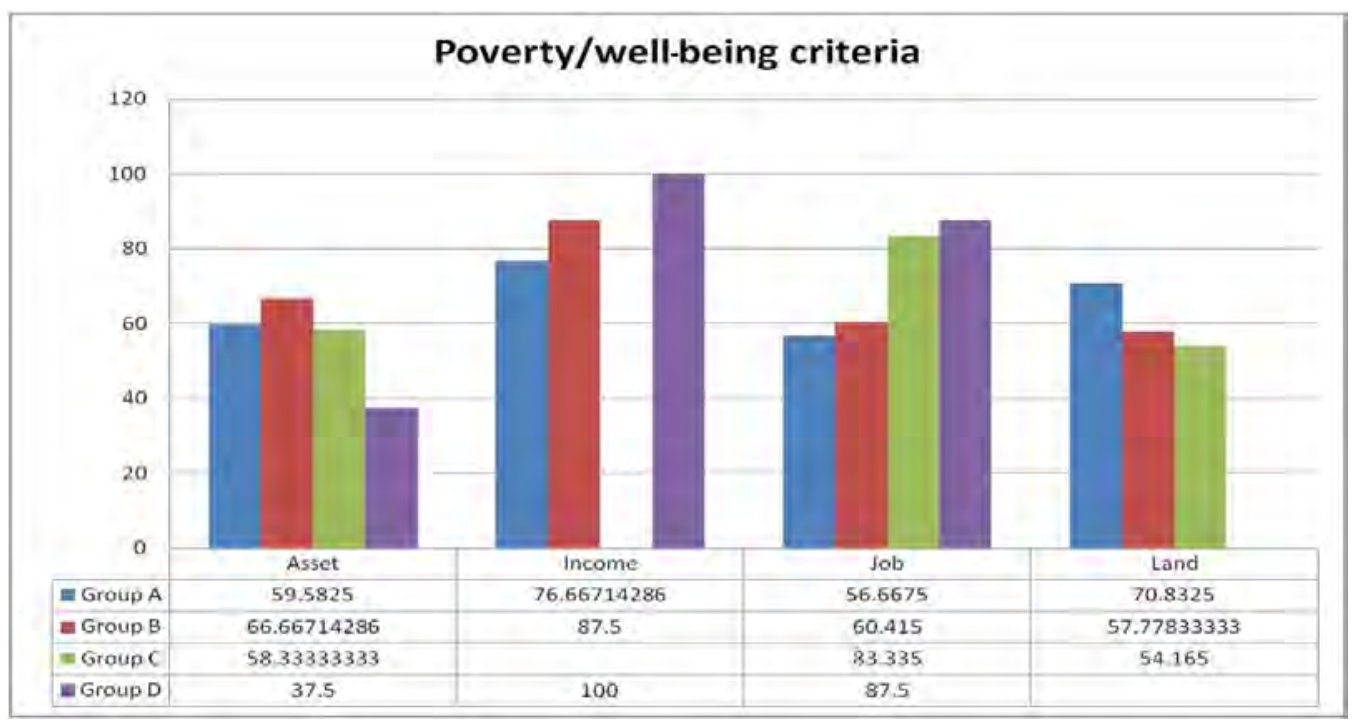

Figure 46. Poverty and/or well-being criteria as perceived by the local community per village typology groups.

Data source: FGD.

Income was the main criteria to define well-being and poverty in each typology group in the study area (Figure 46). However, in Group C (Tasahea), income was not considered as important to define poverty. People within this village stated that a certain job, assets and land were the main criteria to define well-being. Within Group D, land was not considered important, but that a regular income 
from a certain job was important to indicate well-being, while people with very low incomes with jobs such as free labour or no occupation were defined as poor.

Communities were asked to assess their own conditions of poverty levels from their previous to current condition. This was important to portray how they define their condition based on their poverty or well-being criteria. Well-being patterns from the past to the present were almost the same in each village, moving in the same direction with well-being increasing over time. While women mostly described their well-being status as always increasing, men in some group discussions stated that their current condition was still below that of previous periods in time, due to farm productivity and price fluctuation issues. The causal factors were usually very site-specific, but we can summarize other factors influencing how people perceived their well-being status as listed below.

- Natural cause: pests/diseases, plants and farm production, harvest failure and natural hazards.

- External intervention: technology introduction, plantation and farming programmes from government, electricity.

- Market pressure: price fluctuation.

- Infrastructure development: asphalt roads define accessibility, the more accessible the place, the higher the well-being due to the development.
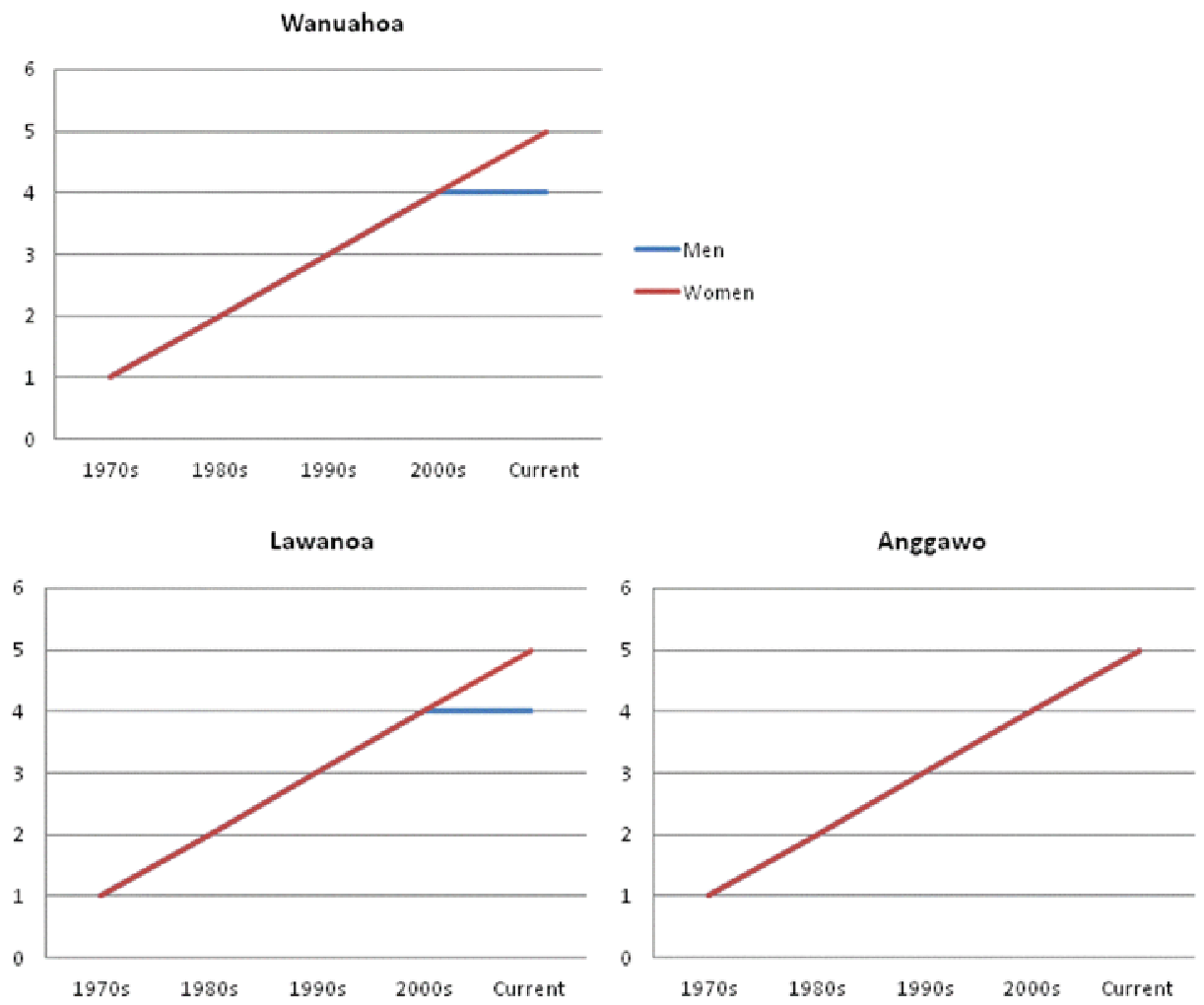

Figure 47. Male and female perceptions in villages within Group B regarding their well-being and poverty status from 1990s to present. Data source: FGD. 

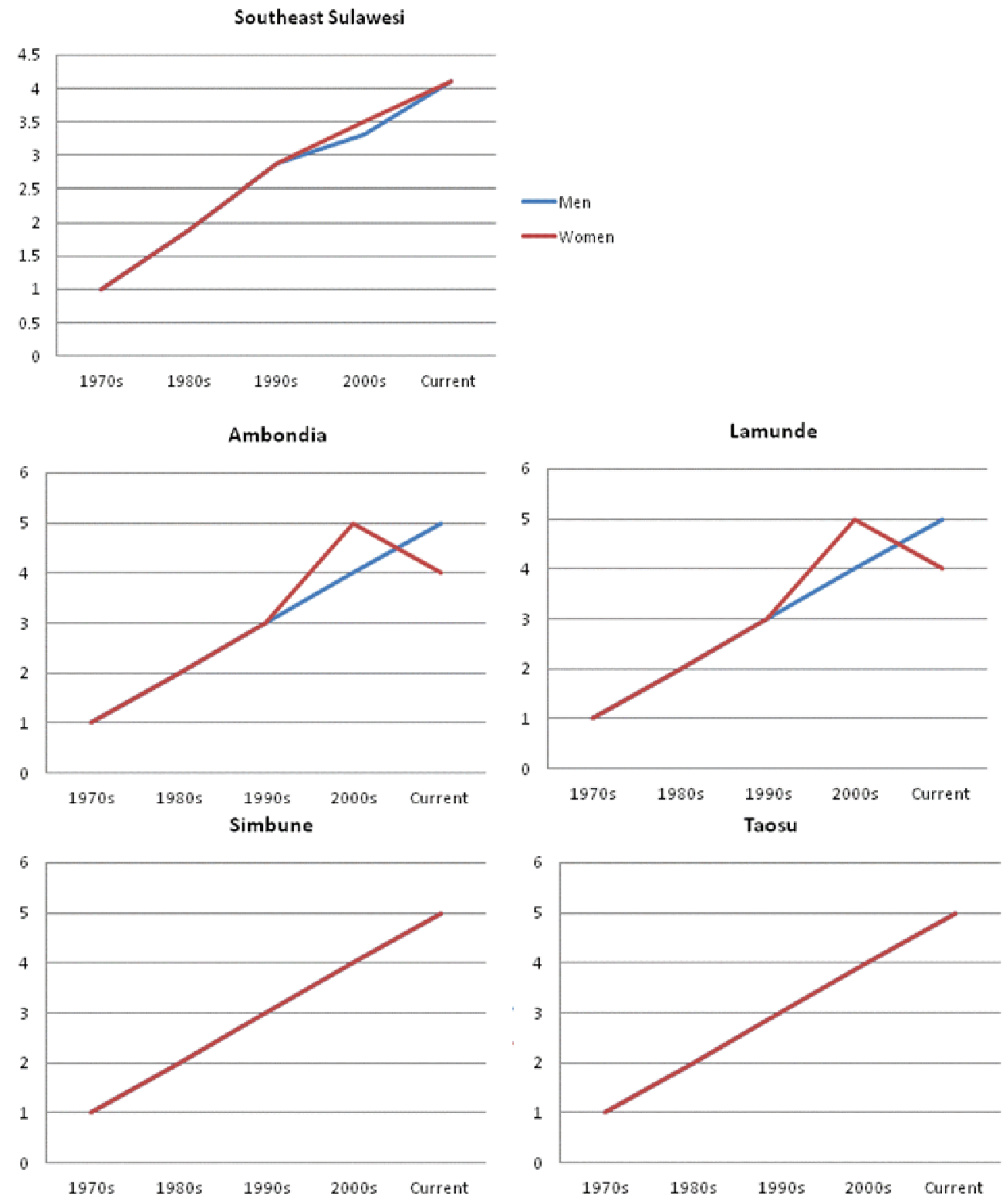

Figure 48. Male and female perceptions in South Sulawesi and villages within Group A regarding their wellbeing and poverty status from 1990s to present. Data source: FGD 


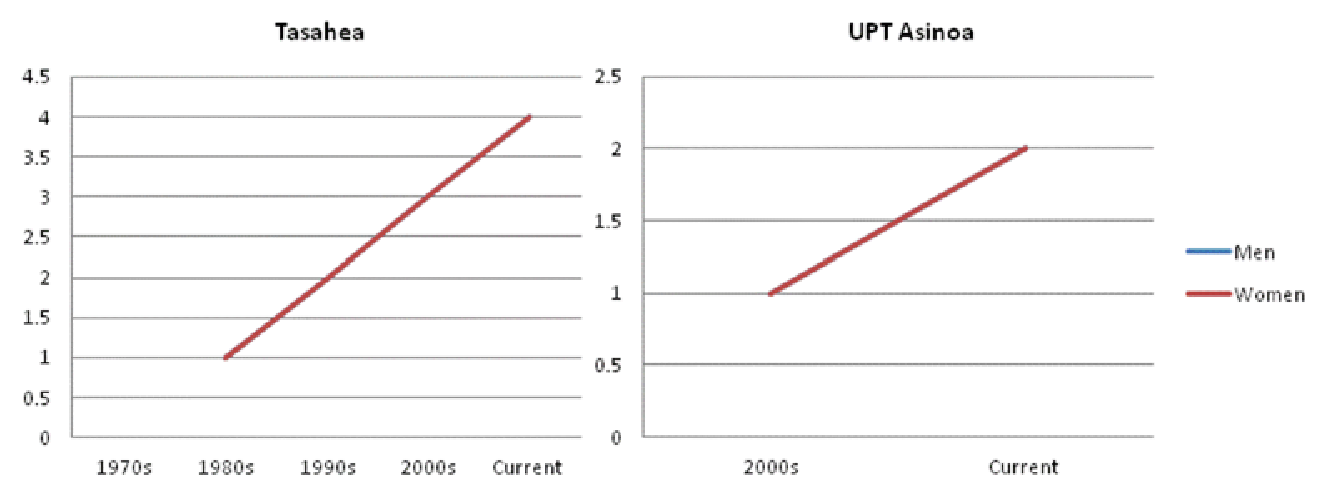

Figure 49. Male and female perceptions in the villages within Group C (Tasahea) and Group D (UPT Asinoa) regarding their well-being and poverty status from 1990s to present. Data source: FGD.

\section{Conclusion}

Gender issues at the provincial level show that gaps exist in relation to development issues. Issues exist relating to inequality between women and men, as demonstrated by the GDI and GEI levels which are below the national levels. Therefore an integrated program must be implemented to promote women's involvement at community level (considering women as income earners) and also at meso level, so that women are able to become more involved in the parliamentary and decisionmaking processes within the home and community.

Women and men had different roles in managing households, faming activities and natural resources. For the areas of household, farm production, land use management, and marketing women were mostly responsible for domestic tasks and maintaining the land located close to the settlement area. Men were mostly responsible for earning income from working in the public domain, and were fully responsible for maintaining the land that is located far from the settlement area, and for physically heavy work. The close proximity of the area of work to the house complex was favourable for women so that they could still undertake productive work but also meet their domestic responsibilities.

The relationship between gender and land was discussed regarding land rights and ownership, as well as how gender influences perceptions of land use and function. Regarding land rights, it appears that women are still under-acknowledged as land holders due to most of the land certificates being only under male names. Providing more conducive conditions for women to become land owners and legalized in land certificates would increase equity in terms of land rights and ownership. The 
problem may not be complicated if women were not heading the household, but for women who were heads of households, this situation was not equal. In relation to how gender influenced the perceptions of land-use value, importance and function, women and men had different perceptions.

The data in the two provinces clearly shows that women and men have different important roles regarding natural resource management. The different roles reflect different needs and interests in handling the resources. The data shows that women are more knowledgeable about land use values in regards to environmental issues related with biodiversity, while men are more aware of conservation or protecting the environment. Biodiversity in this context related to medicinal plants. Women were also known to possess more knowledge about the use of medicinal plants. Therefore, providing women the ability to be more involved in land-use management will help to maintain biodiversity and also enhance the role of women.

The market chain in Sulawesi, in particular in South and Southeast Sulawesi, has already taken women into account. Women have equal positions in marketing and responsibility for cacao, clove and coffee marketing. However, the producer or villager is at the end of the market chain and without access to knowledge of market and related product (quality, price) information they have little room to expand their opportunities/income.

Recommended criteria and indicators for gender empowerment:

- In terms of the relationship between land and gender: Developing conducive situations to allow women the possibility of becoming landholders and legalized in land certificates, in particular for female-headed households.

- In terms of gender, household and farming activities: Providing opportunities for women to be involved in public, extension services, technical assistance, credit and other activities (Martini et al 2013), designed to be located close to women's areas within villages.

- In relation to gender and livelihood sources: A program to target the livelihood source preferred by both women and men, such as mixed-gardens, irrigated paddy fields and maize production in South Sulawesi;

- In relation to gender and the market: Women's knowledge of cacao, coffee, and clove products in term of their quality should be increased, providing women to be enabled with strong bargaining skills not only in term of price but also in their position within the market chain. 



\section{References}

[BPS] Biro Pusat Statistik and Kementrian Pemberdayaan Perempuan dan Perlindungan Anak. 2012. Pembangunan Manusia Berbasis Gender Tahun 2005-2011.

Arafah N. 2002. Pengetahuan Lokal Suku Moronene Dalam Sistem Pertanian di Sulawesi Tenggara. Masters Thesis: Bogor, Indonesia: Bogor Agricultural University.

Boserup E. 1970. Women's role in economic development. London: Earthscan.

Cornwall A. 2007. Revisiting the 'gender agenda.' IDS Bulletin 38(2): 69-78.

Dankelman I, Davidson J, eds. 1988. Women and environment in the third world: alliance for the future. London: Earthscan.

Elmhirst R, Ressureccion BP. 2008. Gender, environment and natural resource management: new dimensions, new debates. London: Earthscan.

Graham S. 2001. Negotiating Gender: Calalai' in Bugis Society. Intersections: Gender, History and Culture in the Asian Context. 6 [no page number]. Available from: $\mathrm{http}: / /$ intersections.anu.edu.au/issue6/graham.html

Grauer R. 2004. The last Bissu: sacred tranvestites of I La Galigo. Bali: Manitou Media Ltd.

Idrus NI. 2003. 'To take each other': Bugis Practice of Gender, Sexuality and Marriage. PhD Thesis. Canberra: Australian National University. (Available from http://hdl.handle.net/1885/47288)

International Fund for Agricultural Development. 2009. Gender in Agriculture Sourcebook. World Bank Publications.

(http://siteresources.worldbank.org/INTGENAGRLIVSOUBOOK/Resources/CompleteBook.pdf)

Janudianto, N Khususiyah Isnurdiansyah, Suyanto, Roshetko JM. 2012. Agroforestry and Forestry in Sulawesi series: Livelihoods strategies and land-use system dynamics in Southeast Sulawesi. ICRAF Working Paper no 156.

Kennedy E, Peters P. 1992. Household food security and child nutrition: the interaction of income and gender of household head. World Development 20(8), 1077-1085.

Khususiyah N, Janudianto, Isnurdiansyah, Suyanto, Roshetko JM. 2012. Agroforestry and Forestry in Sulawesi series: Livelihoods strategies and land-use system dinamics in South Sulawesi. ICRAF Working Paper no. 155.

Kiptot E, Franzel S. 2011. Gender and agroforestry in Africa: are women participating? World Agroforestry Centre (ICRAF) Occasional Paper No. 13. Nairobi: World Agroforestry Centre.

Lewis MP, ed. 2009. Ethnologue: languages of the world. Sixteenth edition. Dallas, TX: SIL International. (Available from: http://www.ethnologue.com/) (Accessed on $9^{\text {th }}$ July 2012)

Martini E, Tarigan J, Purnomosidhi P, Prahmono A, Surgana M, Setiawan A, Megawati, Mulyoutami E, Meldy BD, Syamsidar, Talui R, Janudianto, Suyanto S, Roshetko JM. 2012. Agroforestry and Forestry in Sulawesi series: Agroforestry extension needs at the community level in AgFor project sites in South and Southeast Sulawesi, Indonesia. ICRAF Working Paper no. 159.

McGregor J. 1994. Climate change and involuntary migration: implications for food security. Food Policy 19(2):120-132. 
McLeman R, Smit B. 2006. Migration as an adaptation to climate change. Climatic change 76 : 31-53.

Moser CON. 1993. Gender planning and development: theory, practice, and training. London: Routledge.

Mosse JC. 1993. Half of the world, half a chance: an introduction to gender and development. Oxford: Oxfam.

Overholt C, Anderson M, Cloud K, Austin J. 1985. Gender roles in development projects: cases for planners. West Hartford, CT: Kumarian Press.

Perdana A, Roshetko JM. 2012. Agroforestry and Forestry in Sulawesi series: Rapid market appraisal of agricultural, plantation and forestry commodities in South and Southeast Sulawesi. ICRAF Working Paper no. 160..

Portes A. 2010. Economic Sociology: a systematic inquiry. New Jersey: Princeton University Press.

Quisumbing AR, Brown LR, Feldstein HS, Haddad L, Peña C. 1995. Women: the key to food security. Washington, DC: International Food Policy Research Institute.

Quisumbing AR, Pandolfellu L. 2010. Promising approaches to address the needs of poor female farmers: resources, constraints and intervention. World Development 38(4): 581-592.

Raleigh C, Jordan L, Salehyan I. 2008. Assessing the impact of climate change on migration and conflict. The World Bank Social Dimensions of Climate Change workshop, 5-6 March. Washington, DC: The World Bank.

Rao A, Anderson MB, Overhold C. 1991. Gender analysis in development planning: a case book. West Hartford, CT: Kumarian Press.

Rocheleau D. 1991. Gender, ecology and the science of survival: stories and lesson from Kenya. Agriculture and Human Values 8:156-165.

Sachs C. 1996. Gendered fields: rural women, agriculture, and environment. Boulder, CO: Westview Press.

Shiva V. 1988. Staying alive: women, ecology and nature. New Delhi: Kali for Women; London: Zed books.

Swedberg R. 2005. Markets in society. In: Smelser NJ, Swedberg R. eds. The handbook of economic sociology. New Jersey: Princeton University Press. p 233-252.

World Bank, Food and Agriculture Organization, International Fund for Agricultural Development. 2009. Gender in Agriculture Sourcebook. Washington, DC: International Bank for Reconstruction and Development, The World Bank. (Available from http://worldbank.org/genderinag). 


\section{WORKING PAPERS IN THIS SERIES}

2005

1. Agroforestry in the drylands of eastern Africa: a call to action

2. Biodiversity conservation through agroforestry: managing tree species diversity within a network of community-based, nongovernmental, governmental and research organizations in western Kenya.

3. Invasion of prosopis juliflora and local livelihoods: Case study from the Lake Baringo area of Kenya

4. Leadership for change in farmers organizations: Training report: Ridar Hotel, Kampala, 29th March to 2nd April 2005.

5. Domestication des espèces agroforestières au Sahel: situation actuelle et perspectives

6. Relevé des données de biodiversité ligneuse: Manuel du projet biodiversité des parcs agroforestiers au Sahel

7. Improved land management in the Lake Victoria Basin: TransVic Project's draft report.

8. Livelihood capital, strategies and outcomes in the Taita hills of Kenya

9. Les espèces ligneuses et leurs usages: Les préférences des paysans dans le Cercle de Ségou, au Mali

10. La biodiversité des espèces ligneuses: Diversité arborée et unités de gestion du terroir dans le Cercle de Ségou, au Mali

2006

11. Bird diversity and land use on the slopes of Mt. Kilimanjaro and the adjacent plains, Tanzania

12. Water, women and local social organization in the Western Kenya Highlands

13. Highlights of ongoing research of the World Agroforestry Centre in Indonesia

14. Prospects of adoption of tree-based systems in a rural landscape and its likely impacts on carbon stocks and farmers' welfare: The FALLOW Model Application in Muara Sungkai, Lampung, Sumatra, in a 'Clean Development Mechanism' context

15. Equipping integrated natural resource managers for healthy Agroforestry landscapes.

17. Agro-biodiversity and CGIAR tree and forest science: approaches and examples from Sumatra.

18. Improving land management in eastern and southern Africa: A review of policies.

19. Farm and household economic study of Kecamatan Nanggung, Kabupaten Bogor, Indonesia: A socioeconomic base line study of Agroforestry innovations and livelihood enhancement.

20. Lessons from eastern Africa's unsustainable charcoal business.

21. Evolution of RELMA's approaches to land management: Lessons from two decades of research and development in eastern and southern Africa

22. Participatory watershed management: Lessons from RELMA's work with farmers in eastern Africa.

23. Strengthening farmers' organizations: The experience of RELMA and ULAMP.

24. Promoting rainwater harvesting in eastern and southern Africa.

25. The role of livestock in integrated land management.

26. Status of carbon sequestration projects in Africa: Potential benefits and challenges to scaling up.

27. Social and Environmental Trade-Offs in Tree Species Selection: A Methodology for Identifying Niche Incompatibilities in Agroforestry [Appears as AHI Working Paper no. 9]

28. Managing tradeoffs in agroforestry: From conflict to collaboration in natural resource management. [Appears as AHI Working Paperno. 10]

29. Essai d'analyse de la prise en compte des systemes agroforestiers pa les legislations forestieres au Sahel: Cas du Burkina Faso, du Mali, du Niger et du Senegal.

30. Etat de la recherche agroforestière au Rwanda etude bibliographique, période 1987-2003

2007

31. Science and technological innovations for improving soil fertility and management in Africa: A report for NEPAD's Science and Technology Forum.

32. Compensation and rewards for environmental services.

33. Latin American regional workshop report compensation.

34. Asia regional workshop on compensation ecosystem services.

35. Report of African regional workshop on compensation ecosystem services. 
36. Exploring the inter-linkages among and between compensation and rewards for ecosystem services CRES and human well-being

37. Criteria and indicators for environmental service compensation and reward mechanisms: realistic, voluntary, conditional and pro-poor

38. The conditions for effective mechanisms of compensation and rewards for environmental services.

39. Organization and governance for fostering Pro-Poor Compensation for Environmental Services.

40. How important are different types of compensation and reward mechanisms shaping poverty and ecosystem services across Africa, Asia \& Latin America over the Next two decades?

41. Risk mitigation in contract farming: The case of poultry, cotton, woodfuel and cereals in East Africa.

42. The RELMA savings and credit experiences: Sowing the seed of sustainability

43. Yatich J., Policy and institutional context for NRM in Kenya: Challenges and opportunities for Landcare.

44. Nina-Nina Adoung Nasional di So! Field test of rapid land tenure assessment (RATA) in the Batang Toru Watershed, North Sumatera.

45. Is Hutan Tanaman Rakyat a new paradigm in community based tree planting in Indonesia?

46. Socio-Economic aspects of brackish water aquaculture (Tambak) production in Nanggroe Aceh Darrusalam.

47. Farmer livelihoods in the humid forest and moist savannah zones of Cameroon.

48. Domestication, genre et vulnérabilité : Participation des femmes, des Jeunes et des catégories les plus pauvres à la domestication des arbres agroforestiers au Cameroun.

49. Land tenure and management in the districts around Mt Elgon: An assessment presented to the Mt Elgon ecosystem conservation programme.

50. The production and marketing of leaf meal from fodder shrubs in Tanga, Tanzania: A pro-poor enterprise for improving livestock productivity.

51. Buyers Perspective on Environmental Services (ES) and Commoditization as an approach to liberate ES markets in the Philippines.

52. Towards Towards community-driven conservation in southwest China: Reconciling state and local perceptions.

53. Biofuels in China: An Analysis of the Opportunities and Challenges of Jatropha curcas in Southwest China.

54. Jatropha curcas biodiesel production in Kenya: Economics and potential value chain development for smallholder farmers

55. Livelihoods and Forest Resources in Aceh and Nias for a Sustainable Forest Resource Management and Economic Progress

56. Agroforestry on the interface of Orangutan Conservation and Sustainable Livelihoods in Batang Toru, North Sumatra.

57. Assessing Hydrological Situation of Kapuas Hulu Basin, Kapuas Hulu Regency, West Kalimantan.

58. Assessing the Hydrological Situation of Talau Watershed, Belu Regency, East Nusa Tenggara.

59. Kajian Kondisi Hidrologis DAS Talau, Kabupaten Belu, Nusa Tenggara Timur.

60. Kajian Kondisi Hidrologis DAS Kapuas Hulu, Kabupaten Kapuas Hulu, Kalimantan Barat.

61. Lessons learned from community capacity building activities to support agroforest as sustainable economic alternatives in Batang Toru orang utan habitat conservation program (Martini, Endri et al.)

62. Mainstreaming Climate Change in the Philippines.

63. A Conjoint Analysis of Farmer Preferences for Community Forestry Contracts in the Sumber Jaya Watershed, Indonesia.

64. The highlands: a shared water tower in a changing climate and changing Asia

65. Eco-Certification: Can It Deliver Conservation and Development in the Tropics.

66. Designing ecological and biodiversity sampling strategies. Towards mainstreaming climate change in grassland management.

67. Towards mainstreaming climate change in grassland management policies and practices on the Tibetan Plateau

68. An Assessment of the Potential for Carbon Finance in Rangelands

69 ECA Trade-offs Among Ecosystem Services in the Lake Victoria Basin.

69. The last remnants of mega biodiversity in West Java and Banten: an in-depth exploration of RaTA (Rapid Land Tenure Assessment) in Mount Halimun-Salak National Park Indonesia

70. Le business plan d'une petite entreprise rurale de production et de commercialisation des plants des arbres locaux. Cas de quatre pépinières rurales au Cameroun. 
71. Les unités de transformation des produits forestiers non ligneux alimentaires au Cameroun. Diagnostic technique et stratégie de développement Honoré Tabuna et Ingratia Kayitavu.

72. Les exportateurs camerounais de safou (Dacryodes edulis) sur le marché sous régional et international. Profil, fonctionnement et stratégies de développement.

73. Impact of the Southeast Asian Network for Agroforestry Education (SEANAFE) on agroforestry education capacity.

74. Setting landscape conservation targets and promoting them through compatible land use in the Philippines.

75. Review of methods for researching multistrata systems.

76. Study on economic viability of Jatropha curcas L. plantations in Northern Tanzania assessing farmers' prospects via cost-benefit analysis

77. Cooperation in Agroforestry between Ministry of Forestry of Indonesia and International Center for Research in Agroforestry

78. "China's bioenergy future. an analysis through the Lens if Yunnan Province

79. Land tenure and agricultural productivity in Africa: A comparative analysis of the economics literature and recent policy strategies and reforms

80. Boundary organizations, objects and agents: linking knowledge with action in agroforestry watersheds

81. Reducing emissions from deforestation and forest degradation (REDD) in Indonesia: options and challenges for fair and efficient payment distribution mechanisms

2009

82. Mainstreaming climate change into agricultural education: challenges and perspectives

83. Challenging conventional mindsets and disconnects in conservation: the emerging role of eco-agriculture in Kenya's landscape mosaics

84. Lesson learned RATA garut dan bengkunat: suatu upaya membedah kebijakan pelepasan kawasan hutan dan redistribusi tanah bekas kawasan hutan

85. The emergence of forest land redistribution in Indonesia

86. Commercial opportunities for fruit in Malawi

87. Status of fruit production processing and marketing in Malawi

88. Fraud in tree science

89. Trees on farm: analysis of global extent and geographical patterns of agroforestry

90. The springs of Nyando: water, social organization and livelihoods in Western Kenya

91. Building capacity toward region-wide curriculum and teaching materials development in agroforestry education in Southeast Asia

92. Overview of biomass energy technology in rural Yunnan (Chinese - English abstract)

93. A pro-growth pathway for reducing net $\mathrm{GHG}$ emissions in China

94. Analysis of local livelihoods from past to present in the central Kalimantan Ex-

Mega Rice Project area

95. Constraints and options to enhancing production of high quality feeds in dairy production in Kenya, Uganda and Rwanda

2010

96. Agroforestry education in the Philippines: status report from the Southeast Asian Network for Agroforestry Education (SEANAFE)

97. Economic viability of Jatropha curcas L. plantations in Northern Tanzania- assessing farmers' prospects via cost-benefit analysis.

98. Hot spot of emission and confusion: land tenure insecurity, contested policies and competing claims in the central Kalimantan Ex-Mega Rice Project area

99. Agroforestry competences and human resources needs in the Philippines

100. CES/COS/CIS paradigms for compensation and rewards to enhance environmental Services

101. Case study approach to region-wide curriculum and teaching materials development in agroforestry education in Southeast Asia

102. Stewardship agreement to reduce emissions from deforestation and degradation (REDD): Lubuk Beringin's Hutan Desa as the first village forest in Indonesia

103. Landscape dynamics over time and space from ecological perspective 
104. Komoditisasi atau koinvestasi jasa lingkungan: skema imbal jasa lingkungan program peduli sungai di DAS Way Besai, Lampung, Indonesia

105. Improving smallholders' rubber quality in Lubuk Beringin, Bungo district, Jambi province, Indonesia: an initial analysis of the financial and social benefits

106. Rapid Carbon Stock Appraisal (RACSA) in Kalahan, Nueva Vizcaya, Philippines

107. Tree domestication by ICRAF and partners in the Peruvian Amazon: lessons learned and future prospects in the domain of the Amazon Initiative eco-regional program

108. Memorias del Taller Nacional: "Iniciativas para Reducir la Deforestación en la region Andino Amazónica", 09 de Abril del 2010. Proyecto REALU Peru

109. Percepciones sobre la Equidad y Eficiencia en la cadena de valor de REDD en Perú - Reporte de Talleres en Ucayali, San Martín y Loreto, 2009. Proyecto REALU-Perú.

110. Reducción de emisiones de todos los Usos del Suelo. Reporte del Proyecto REALU Perú Fase 1

111. Programa Alternativas a la Tumba-y-Quema (ASB) en el Perú. Informe Resumen y Síntesis de la Fase II. 2da. versión revisada

112. Estudio de las cadenas de abastecimiento de germoplasma forestal en la amazonía Boliviana

113. Biodiesel in the Amazon

114. Estudio de mercado de semillas forestales en la amazonía Colombiana

115. Estudio de las cadenas de abastecimiento de germoplasma forestal en Ecuador

116. How can systems thinking, social capital and social network analysis help programs achieve impact at scale?

117. Energy policies, forests and local communities in the Ucayali Region, Peruvian Amazon

118. NTFPs as a Source of Livelihood Diversification for Local Communities in the Batang Toru Orangutan Conservation Program

119. Studi Biodiversitas: Apakah agroforestry mampu mengkonservasi keanekaragaman hayati di DAS Konto?

120. Estimasi Karbon Tersimpan di Lahan-lahan Pertanian di DAS Konto, Jawa Timur

121. Implementasi Kaji Cepat Hidrologi (RHA) di Hulu DAS Brantas, Jawa Timur.

122. Kaji Cepat Hidrologi di Daerah Aliran Sungai Krueng Peusangan, NAD,Sumatra

123. A Study of Rapid Hydrological Appraisal in the Krueng Peusangan Watershed, NAD, Sumatra.

\section{1}

124. An Assessment of farm timber value chains in Mt Kenya area, Kenya

125. A Comparative financial analysis of current land use systems and implications for the adoption of improved agroforestry in the East Usambaras, Tanzania

126. Agricultural monitoring and evaluation systems

127. Challenges and opportunities for collaborative landscape governance in the East Usambara Mountains, Tanzania

128. Transforming Knowledge to Enhance Integrated Natural Resource Management Research, Development and Advocacy in the Highlands of Eastern Africa

129. Carbon-forestry projects in the Philippines: potential and challenges The Mt Kitanglad Range forestcarbon development

130. Carbon forestry projects in the Philippines: potential and challenges. The Arakan Forest Corridor forestcarbon project

131. Carbon-forestry projects in the Philippines: potential and challenges. The Laguna Lake Development Authority's forest-carbon development project

132. Carbon-forestry projects in the Philippines: potential and challenges. The Quirino forest-carbon development project in Sierra Madre Biodiversity Corridor

133. Carbon-forestry projects in the Philippines: potential and challenges. The Ikalahan ancestral domain forest-carbon development

134. The Importance of Local Traditional Institutions in the Management of Natural Resources in the Highlands of Eastern Africa

135. Socio-economic assessment of irrigation pilot projects in Rwanda

136. Performance of three rambutan varieties(Nephelium lappaceum L.) on various nursery media

137. Climate change adaptation and social protection in agroforestry systems: enhancing adaptive capacity and minimizing risk of drought in Zambia and Honduras 
138. Does value chain development contribute to rural poverty reduction? Evidence of asset building by smallholder coffee producers in Nicaragua

139. Potential for biofuel feedstock in Kenya

140. Impact of fertilizer trees on maize production and food security in six districts of Malawi.

\section{2}

141. Fortalecimiento de capacidades para la gestión del Santuario Nacional Pampa Hermosa: Construyendo las bases para un manejo adaptativo para el desarrollo local. Memorias del Proyect

142. Understanding rural institutional strengthening: A cross-level policy and institutional framework for sustainable development in Kenya

143. Climate change vulnerability of agroforestry

144. Rapid assesment of the inner Niger delta of Mali

145. Designing an incentive program to reduce on-farm deforestationin the East Usambara Mountains, Tanzania

146. Extent of adoption of conservation agriculture and agroforestry in Africa: the case of Tanzania, Kenya, Ghana, and Zambia

147. Policy incentives for scaling up conservation agriculture with trees in Africa: the case of Tanzania, Kenya, Ghana and Zambia

148. Commoditized or co-invested environmental services? Rewards for environmental services scheme: River Care program Way Besai watershed, Lampung, Indonesia.

149. Assessment of the headwaters of the Blue Nile in Ethiopia.

150. Assessment of the uThukela Watershed, Kwazaulu.

151. Assessment of the Oum Zessar Watershed of Tunisia.

152. Assessment of the Ruwenzori Mountains in Uganda.

153. History of agroforestry research and development in Viet Nam. Analysis of research opportunities and gaps

154. REDD+ in Indonesia: a Historical Perspective.

155. Agroforestry and Forestry in Sulawesi series: Livelihood strategies and land use system dynamics in South Sulawesi

156. Agroforestry and Forestry in Sulawesi series: Livelihood strategies and land use system dynamics in Southeast Sulawesi.

157 Agroforestry and Forestry in Sulawesi series: Profitability and land-use systems in South and Southeast Sulawesi. 

The World Agroforestry Centre is an autonomous, non-profit research organization whose vision is a rural transformation in the developing world where smallholder households strategically increase their use of trees in agricultural landscapes to improve their food security, nutrition, income, health, shelter, energy resources and environmental sustainability. The Centre generates science-base knowledge about the diverse role that trees play in agricultural landscapes, and uses its research to advance policies and practices that benefit the poor and the environment.

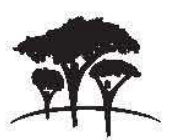

United Nations Avenue, Gigiri • PO Box 30677 • Nairobi, $00100 \cdot$ Kenya Telephone: +254207224000 or via USA +16508336645 Fax: +254207224001 or via USA +1 6508336646 Southeast Asia Regional Program - Sindang Barang, Bogor 16115 PO Box 161 Bogor 16001, Indonesia

Ph: +62 2518625415 - Fax: +62 2518625416

www.worldagroforestry.org/sea 